15.

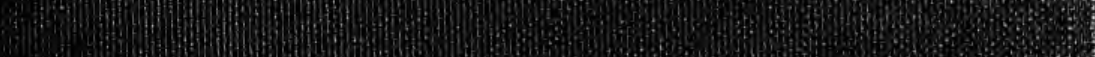
2. (1) (4) 60 $t^{5}$ 2.

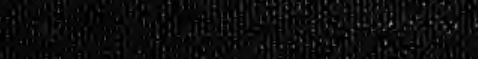



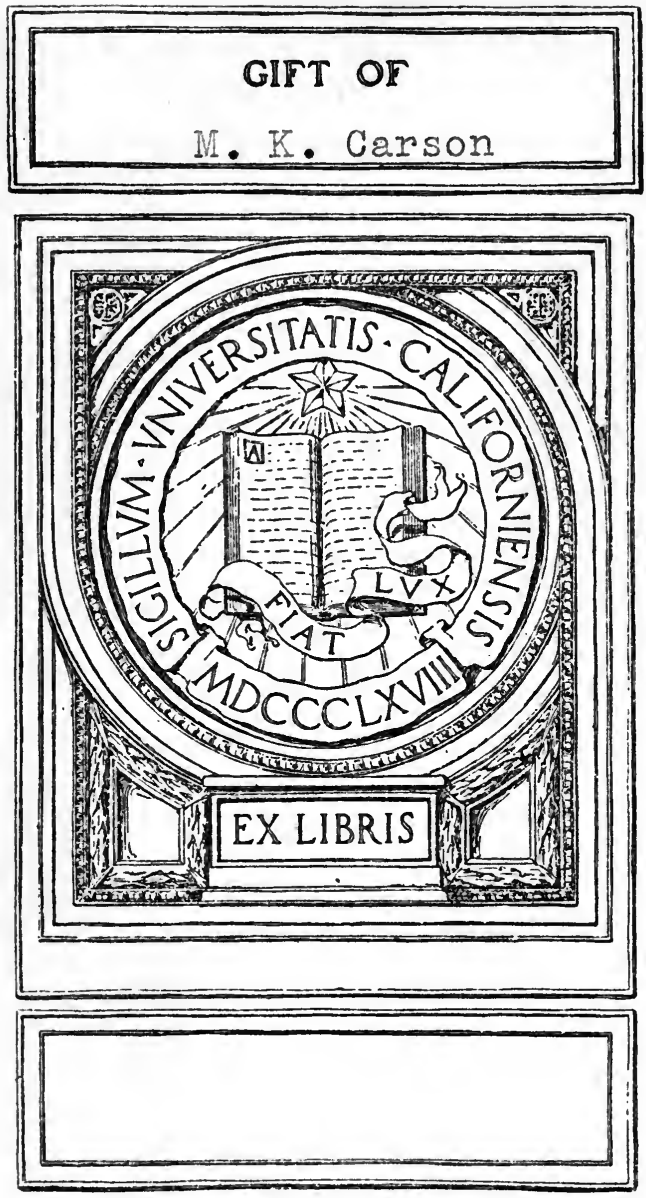


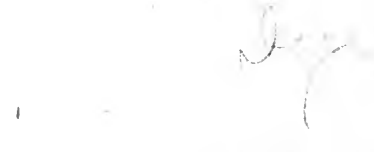


Digitized by the Internet Archive in 2007 with funding from Microsoft Corporation 
SOCIAL ETHICS 



\title{
SOCIAL ETHICS
}

\author{
An Introduction to the
}

Nature and Ethics of the State

\author{
JAMES MELVILLE COLEMAN
}

Storrets Professor of Political Philosophy and History, Geneva College

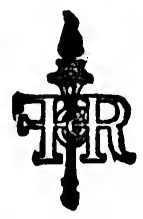

New Yorr
Fleming H. Revell ${ }^{\text {Toronto }}$ Company

LONDON AND EDINBURGH 
Copyright, 1903, 1916, 1922, by FLEMING H. REVELL COMPANY

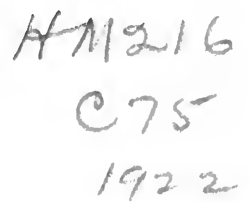

New York: 158 Fifth Avenue Chicago: 17 North Wabash Ave.

London: 21 Paternoster Square Edinburgh: 75 Princes Street. 
TO MY WIFE AND DAUGHTER 


\section{CONTENTS}

CHAPTER I.

The Nature of the Nation-State

CHAPTER II.

Social Institutions

CHAPTER III.

Church and State

CHAPTER IV.

State and the Individual . $\cdot$ -
Factors of Social Union. $\cdot$ CHAPTER V.
CHAPTER VI.

State and the Individual . $\cdot$ C
Factors of Social Union . $\cdot$ CHAPTER V.
CHAPTER VI.

State and the Individual .
Factors of Social Union . $\cdot$ CHAPTER V.
CHAPTER VI.

Social Mind.

CHAPTER VII.

Social Conscience

\section{CHAPTER VII.}

CHAPTER VIII.

Social Forces

CHAPTER IX.

Sovereignty of the State.

CHAPTER $\mathrm{X}$.

Law •. • • • $\begin{array}{cccc}\cdot & \cdot & \cdot \\ \text { CHAPTER XI. }\end{array}$

Authority.

CHAPTER XII.

General Principles of Authority • . . • • • $27 \mathrm{I}$

CHAPTER XIII.

The Social Confession of Christ - • • • . • 286

CHAPTER XIV.

What Constitutes a Christian State 


\section{FOREWORD}

NINETEEN hundred years ago an exile of the Roman Empire was on a lonely Rock in the Ægean. He was not there because he had done his neighbor wrong, but because he believed in the coming of an organized society which would not rest on injustice. He had even dared to promise the coming of this new social order to the toilers that he met.

Standing on this rock lookout the exile saw a new Empire rise such as the world had never known. In it were no slaves, there were none that suffered wrong and the ruler was a workman with calloused hands. While he looked he listened, and through the stillness came a voice. "The kingdoms of this world are become the Kingdom of our Lord and of His Christ." The exile believed in the vision and the voice. He told what he had seen and heard to others and they with gladness believed with him. It was their confidence that not only is there an individual, but a social soul, to be saved. Before both of them is righteousness and the Kingdom of God and the approach is through a divine man who calls himself The Way.

After nineteen centuries the vision of the exile is not realized and those who have trusted in it must still walk by faith. The curse of sin still rests on the fairest works of God. War and hatred and greed and tears are yet the 
burden of the peoples. Satan still holds the kingdoms of the world. But we believe in the vision and in the conquering power of the imperial Christ.

It is in this faith that this little book is written and sent out with its halting message. If America is to be saved her citizens must learn that she is a soul and needs a Savior. They must learn that our real dangers are from internal sin and not from external foes. Men have tried all other paths to peace with their fellowmen except that way that lies through peace with God. And they have failed. There is a Way, and if these chapters aid in the humblest degree in pointing out this Way and in making America loyal to her Christ they will have served their purpose. 


\section{PREFACE.}

IN these days, when the social mind is troubled with a plethora of books, the writer who proposes an addition to the number should be ready to give a reason for the hope that is in him. There is no lack of social studies, but it seems to me that there is room for a book which treats social phenomena from a distinctively Christian point of view, and yet gives adequate place to the conclusions of science and philosophy. What is wanted is a Christian cosmic philosophy, for philosophy must be Christian to be cosmic.

Mr. Herbert Spencer tried to build a cosmic philosophy on the basis of matter and motion; Mr. John Fiske went so far as to admit that science could not disprove immortality; but the last word on the philosophy of the universe must not ignore spiritual facts. Science must come to recognize the fact that spirit is supreme over matter, rather than dependent on matter for existence.

I believe that the student must look at the facts of the universe from the position of Jesus, if he is to gain the proper perspective. Thus may he hope to find the harmony of the universe. "In Him all things consist," and the view which leaves Jesus Christ out of the universe, or makes Him anything less than a controlling factor, is fatally defective. These pages have no such ambitious aim as the statement of a world philosophy, yet the declaration is ventured that the cosmic philosophy, 


\section{PREFACE}

when stated, will include these premises. Jesus Christ must be taken as the point of departure and approach. His will must be seen as the governing agency in matter; His teachings must be accepted as the ultimate rule of human life. This is the view with which these pages have been written.

This work, put together in the broken time of continuous school work, was designed specially for the convenience of my classes, but I am not without the hope that it may serve the same purpose for other teachers, and that the general reader will not find it altogether unsuited to his needs. With this latter class in mind, technical matter has been omitted as far as possible. Not to the classroom alone can be left the solution of the social problem, which solution is the social crowning of the Christ.

Foot-note references have been omitted, and instead reference is made to books and chapters, in the hope that the reader may not rest satisfied with the reading of detached sentences, but will study the author for himself. For the most part, however, the attempt has been made to interpret the commonplace facts, which are so familiar as to need no reference.

In order to avoid the difficulty, peculiar to American politics, of confusing the "State," the social spirit, with the "State" as a member of the Federal Union, the word Commonwealth has been substituted for "State" in the latter sense.

I am indebted to my brother, Rev. W. J. Coleman, through whose suggestion this work was undertaken, 


\section{PREFACE}

and whose advice has been of great service in its preparation. The discussion of authority has its basis in a course of lectures delivered by him in Geneva College. The conception of the State and the relation which it bears to social institutions, is drawn from the teaching and the writings of Professor John Dewey.

Scarcely less than to these do I owe a debt of gratitude to the students, past and present, whose keen criticisms in class discussions have weeded out some of the defects in the book, and to others who have given their time to the correcting of the pages as they passed through the press.

Fully conscious that this work is not a final statement of the views which it aims to present, I give it to the public in the hope that it may point the way to some complete embodiment of the social truth which shall "make us free," 


\section{SOCIAL ETHICS}

\section{THE NATURE OF THE NATION-STATE ${ }^{1}$}

TOMMY MORGAN had scarcely finished his argument in Chicago Commons that labor difficulties were to be settled by the teachings of Jesus when a stranger was on his feet to answer him.

"What this man has just told you," said the newcomer, "is dead wrong. This world has always been, will always be, ruled by force. By force kings have reigned. By force empires have risen and stood. Force is the world law. What the last speaker has been saying about love is foolishness. Love never has, and never can, rule."

\section{Pagan Ethics.}

This discussion in the free forum of Chicago Commons states the issue which is as old as human history. Is love, or force, the ruling principle of the world of men? It was in the belief that force was supreme in international affairs that Germany made her appeal to the god of war in I9I4 and backed the appeal with all the science of the age.

Some men said then that Christianity had failed because it had not prevented war. Very few would say

${ }^{1}$ Prepared for this edition of Social Ethics. 
that now. They are saying that Christianity has not failed in international relations for the reason that, except in isolated cases, it has not been tried. The diplomacy of the world has been based on force, in fact John Hay was almost the first to propose any other principle. So that when Germany appealed to force she had centuries of diplomacy in her favor.

Then why did Germany fail? Not through lack of preparation! Not through lack of organization! Never was force so well organized, so thoroughly ready, so able to strike savage blows. There is only one reason that seems sufficient and that is that Tommy Morgan was right when he said that there was something in the world stronger than force.

Now if men are matter rather than mind, if they are ruled by material interests and ends, as our Marxian friends tell us they are, then force is the ultimate law. But if men are after all fundamentally mind, then spirit forces must dominate. This was the issue which the Assyrians raised with Hezekiah when they declared that in the name of the god of force the Assyrians had ravaged cities, desolated provinces, and destroyed empires. It was the same pagan language which was used by William Second, when he issued his address to his soldiers on the way to Pekin and that we occasionally read in our own Army and Navy Journal.

Did the answer to the Assyrians when one hundred and eighty-five thousand of their soldiers fell in a night in the Serbonian bog, or the issue of the World War, give any answer to the question whether this world is ruled by impersonal force, or a righteous God? Somewhere, and somehow, we must decide whether human affairs are 
governed by pagan or Christian ethics. And that is decided by whether men are fundamentally matter, or mind. Certainly paganism and Christianity may not finally divide the empire of the world. One, or other, must triumph.

The Ancient Sanction for Pagan Ethics.

Now while pagan ethics, like the poor, is always with us, the sanction for this code has changed with the age. In ancient times the monarchs of Egypt and Assyria, later of Greece and Rome, were supposed to represent the gods of the lands, so that their crimes against humanity were understood to be done in execution of the will of "the gods of things as they are." When Genseric was asked where he was going with his pirate ships he said, "Against the people with whom god is angry." Alexander felt himself so much in need of a divine commission to sanctify his depredations that he went a journey into the desert to have a priest discover his divine lineage.

But as the centuries went by, the pagans in the land of the West ceased to believe in the gods of the old form and it was necessary that the ethics of force should get some new basis, or be discredited and fall into disrepute along with those who lived by its precepts.

\section{The Nere Sanction for Pagan Ethics.}

Somewhat more than half a century ago a quiet Englishman named Charles Darwin announced a theory to the world which has done more to influence the thinking of men, or to justify certain ways of thinking, than any 
other hypothesis of modern times. Nor, as far as the theory itself was concerned, could one have expected such important results, for Darwin himself did not propose it as a philosophy of life. What he claimed to have discovered was the origin of species, while the pagan mind seized upon it as an explanation of the universe of things and men.

What Darwin claimed as the result of his investigations was that animal life, and he did not go beyond that, had been produced in prodigal abundance. And so great was this abundance that the food supply was insufficient, making the attempt to obtain food for the over supply of mouths a struggle for life in which those individuals best suited to the particular environment survived and those less suited perished. Thus we have as a result of variations and the struggle for life what Darwin called the survival of the fittest through natural selection.

This Darwin said was the law of life and progress in the animal world and beyond that limit he modestly did not venture. He left to the adventurers, who followed, the task of using the Darwinian hypothesis for the explanation of things in general from the crayfish to Higher Criticism.

Indeed Darwinism has served purposes of which its author never dreamed. The belief in divine right had been used as the sanction for the ethics of force in behalf of predatory individuals and classes for centuries until it ceased to function. This left the self-interest of industrial and political kings and predatory nations sorely in need of some justification for the practices they had elected to follow and what could be so acceptable to the selfish interests of the world as this theory which made 
struggle and the extermination of the weak as unfit, the law of life.

\section{"Let him get who has the power And let him keep who can,"}

no longer needed an excuse when it was exalted into scientific dogma. So it was not alone its scientific appeal which gave Darwinism its immediate popularity, but also the fact that it gave support to practices of men and nations that were as old as sin. To all such this new scientific contribution was as manna in the desert.

Now since natural selection could be hailed as a law of the universe, not only in the lower forms of life, but also in human affairs, and since human progress was conditioned on struggle through which the fittest was selected, then the extermination of the weaker nation, or the weaker individual, is not only excusable, but commendable. Individual and national selfishness was not only justified but glorified. So natural selection became successively with its devotees a scientific hypothesis to explain the origin of species, a universal theory of life, and finally a religion for those who had no other.

\section{Its Individual and National Application.}

But while Darwinism may be accepted as an ethical code either by individuals, or nations, it is applied in quite a different fashion in the two cases. In its application to the individual it means his development in efficiency through his integration in his own interest, his entire absorption in his struggle for his own hand. As Benjamin Kidd states the case, "It is the science of the causes which have made those who are efficient in the 
struggle for their own interests supreme and omnipotent in the world."

But the integration which makes a nation efficient must be secured in quite a different way. Professor Burgess, who had fully absorbed the Prussian idea of the ethics of force, says there must be a struggle between nations to prevent national stagnation, so international war is necessary to national life. But there must be no civil war. This would destroy the nation. If all the citizens pursued the methods of natural selection the final outcome would be the same as that of the Kilkenny cats.

So in a nation where the ethics of force is taken as the method of international diplomacy, sacrifice is demanded in internal affairs and the more force is applied outward, the greater the demand for sacrifice within. The Prussian citizen was taught to lose himself in the state of which the Kaiser was the visible symbol. Thus did the Prussian ideal of struggle between Germany and other nations that she might have her place in the sun, and the renunciation on the part of the individual citizen within, produce the most efficient fighting force in industry and war that the world has known.

So we can understand Prussian diplomacy. Belgium was weak, France decadent. Therefore the destruction of these nations would be a blessing to humanity, even to these nations themselves, provided that Germany administered the affairs of the deceased. "Weakness," said Treitschke, "is the greatest national crime." Therefore the wiping out of the Serbian nationality would have aided human progress. All the conquerors from Sargon to William Second had acted on the same code of ethics, but only in recent times could it claim a scientific basis. 
Treitschke asserts, "It is hypocrisy to apply the Sermon on the Mount to national life," for while the individual has a duty to sacrifice to national interests, there is nothing higher than the nation for which sacrifice may be made. And every militarist from Berlin to Washington would echo the saying of Treitschke, for this form of pagan belief is not peculiar to any language, or country. Prussianism, which is used here as another name for pagan ethics, is not bounded by political lines. Our boys died to kill it in France and our statesmen practice it in Washington. Prussianism is a state of mind.

Beliefs Rule the World.

Beliefs rule individuals. Belief is related to act as root to fruit. An individual's belief decides his attitude to God and to his neighbors. Paganism is what it is because of its belief. Christianity is such because of its belief. One can be changed into the other by a change of belief. An uncertain faith means an unstable life. "According to thy faith be it unto thee," is prophetic of every life.

Beliefs rule nations. Some have emperors, some kings, and some presidents to reign over them, but everywhere the popular belief guides the affairs of the people. England is not ruled by King George, or by LloydGeorge. England is ruled by what England thinks.

While other peoples looked on the Prussian order as enslaving, the Prussian citizen accepted it as his service to the Fatherland. What made Germany a unity, to her neighbors a deadly unity, was not her army nor her industry, nor her laws. It was her belief. And so great was the enthusiasm of her belief that it induced belief in 
others. She believed so thoroughly that her system of education was the best, that her industry was the best, that other peoples, Americans among them, went to Germany to school. Germany was winning the world to her belief until she broke the spell in I9I4.

When the war correspondent tells his story it is of the clash of bodies of men, large or small, along the line of battle. But that is not the whole story, not even the chief part of it. It was a new belief in Prussia, which Koerner put into song, that turned the tide at Waterloo against Napoleon. The agony of that furrowed field from the North Sea to Switzerland during four years was a conflict of beliefs. Germany made her mistakes, not at all in her military preparations, but in her psychology. She had studied the military plans of other nations, but not their beliefs. So she made her mistakes about Belgium, about England, about the Colonials, about the United States. Military men figure on the number of men and guns they can concentrate at a given point, but beliefs decide the campaign.

Many things have been said and written about how, and when, and where, the Allies won the World War, so one more venture need not be amiss. The war was won on the day when those on both sides of the battle line came to believe that the Allies were somehow fighting for democracy, for the chance for the weaker nations, for the right of each man and each people to express what was in the life. Then the war ceased to mean simply getting so many prisoners, so many dead, so many yards of trenches. Victory, with the new ideal, meant a new world. Along with that new belief the rifle strength of the German army fell off one-half from March to 
October of 19I8. And the man who was able to give to the men in the trenches and the folks at home a new faith and belief was the one, more than any other, who won the war.

That men have been disillusioned since then and have lost their faith, that the governments and the statesmen of the great powers are still following in the beaten path of pagan ethics, does not change the fact that, for a time, the world was in the possession of a new belief which ruled its destinies. And the fact that, even for a brief hour, the world seemed transformed by a new faith shows how the old prophecy may be fulfilled and nations may be born in a day.

Beliefs Change the World.

According to the Darwinian theory of progress through natural selection the process is infinitely slow. Ages are required to make any important change.

But that theory utterly fails to explain the change in Germany in two generations from the ideals of Carl Schurz to those of Treitschke, or the changes in the world since I9I4. "As a man thinketh in his heart so is he." This is no less true of a nation. When a man changes his mind it changes the man. When a nation changes its mind the nation is changed. When Ross tells us about "Changing China," he is writing of the change of the Chinese mind.

Benjamin Kidd says, "There is no form or order of government or of the dominion of force which cannot be removed out of the world in a generation."

President Wilson declares, "There is nothing that can stand in the way of great and triumphant convictions." 
Robert E. Speer writes, "When the Church learns to pray as it has put itself into other activities the Kingdom of God will come." So scientist and statesman and churchman agree that changing the belief of the world will change the world. And that is possible only because individuals and nations are fundamentally mind.

John C. Calhoun struggled to keep the slavery issue out of the field of morals because he knew that if once the conscience of the people pronounced against it, slavery was doomed. That was what killed slavery, what killed the saloon. When that brand is put on any institution it goes out, like Cain, from the presence of men.

The world hates war, our boys died in France to put an end to war. But the governments of the great powers, trained in pagan diplomacy, are busy getting ready for war. More than nine-tenths of the Federal revenue in United States is going for the payment of past and future war. We have done something to put an end to Prussianism in Berlin. What shall we do with it in Washington? One thing seems evident and that is that we can not end war by showing its awful results. Bloch and Angell showed in appalling figures the economic consequence of war, but that did not prevent the debacle of I9I4. Far more appalling are the facts that the World War furnished, but we are proposing to put five hundred millions into battle ships while millions of our neighbors are starving for bread.

The thing that will end war is a passion for peace, for peace that would carry with it a constructive plan for the uplift of humanity. Put into our schools, our press, our pulpits, the devotion to humanity as Germany. 
taught it for two generations for the fatherland and even as it united Germany for the destruction of a continent, it will unite America for the redemption of a world. Germany had the right method but the wrong ideal.

Mazzini told us long ago that the discussion of rights leads only to dissension and war. $\mathrm{He}$ said we must give the place to duties that has been given to rights and that means that the pagan ethics of force must give place to the Christian ethics of service. We have had enough through the years of harping on national rights. The time has come to talk of national duties. We need the passion for peace as a new emotional ideal. "The passion for the ideal is the passion for perfection, which is the passion for God."

\section{This is a Mental World.}

This is not intended for a moment to call in question the fact of matter. No one who stubs his toe as a bare-footed boy, or butts his head against a door in later life, need doubt the fact of matter.

But what I am trying to make clear is that back of matter and always expressing itself through matter is mind. Mind is the fundamental thing. So we have been taking up the issues about which all of us are thinking and showing that they are psychological questions. For if the world is controlled by its ideas, and its ideas and its beliefs all belong to mind, then mind is the fundamental fact, without which we could not explain world movements at all.

Four Social Facts.

These four facts are the individual mind, the national 
mind, the world mind, and the Divine mind. But in stating these as facts $I$ am not thinking that this puts them beyond the sphere of discussion. Indeed, I may admit that each one is called in question by some one. So at this point I wish to preface the discussion by a statement from President King to the effect that "The true definition of anything is what God meant it to be." So if one should believe that the national mind was not very definite so far in United States, or if he felt it necessary to conclude that the world mind was scarcely functioning to date, it would still leave possible the four facts as stated. As for those who question the fact of the divine mind, no evidence for that will be offered in these pages, nor would the discussion have much interest. The Individual Mind.

I think that we may safely take the risk of presuming the fact of the individual mind without discussion. It is true that if one should appeal to the current texts on psychology, in which we may find mind defined as "a stream of consciousness," it does not leave much room for the idea of personality.

However, if the gentle reader will, through an appeal to his own consciousness, conclude that he has a mind, or rather, that he is mind, and will allow the same thing to me, we shall consider the matter as settled. For what we want most to conclude from the fact of mind is the consequent fact of responsibility, responsibility for oneself, for his relationships and for his realization through them.

The World Mind.

Is there a world mind, even in the process of the mak- 
ing? Or, is it only such a dream as Abram had when he went out to find the "city which had foundations"? But whether dream or reality, it is the real question, though it has not been often mentioned, in the discussion of the League of Nations. For if there is no world mind, then there can be no expression of that mind through league, or court, or congress. But if there is a world mind it must find some form of expression. Today with nearly fifty nations in the League, no one is likely to deny its existence, or that it is very much alive. So that if the working of the League is not a proof of the world mind, it may be at least offered as circumstantial evidence.

There is another link of evidence that may be offered. That was the response which came to President Wilson's appeal to make the world safe for democracy, to give the weaker peoples equal place with the strong. We expected a response from the countries of the West, but as well it came from the Arabs of Syria and Mesopotamia, from India, from China, the whole world became articulate in its expression of hope for a new social order "in which dwelleth righteousness." Everywhere, outside of the elements of reaction, was an enthusiasm for freedom such as the world had not known. How shall we understand this unity of acclaim other than the infant cry of a new world? How shall we understand that peoples without a press, without organization, almost without education, should have given expression to the same ideals for the days to come. To me it means that the tribune of the peoples called and the peoples answered. And the answer was as that of a single mind. 
The Nation-State is the Social Mind.

In the months preceding the World War a young man left Kansas to finish his school training in a German university. He had grown up in the freedom that is characteristic of life in the Middle West, had been trained in a home and a church where war, all war, is accounted a sinful thing. His ideals were as far removed from those of Prussia as they might well be, so when he found himself in a class room of the University of Leipsic he was, indeed, in a foreign land.

Then came the fateful days of I9I4. The flag of the Empire was everywhere, the bands were playing, his comrades had left their places in the university to fall in line at the barracks, even the gray-haired and spectacled professors were volunteering for some kind of war work. "Der Tag" for which Germany had been waiting and training had come and found her ready to the last button.

In this storm of national feeling the boy from Kansas was caught and carried away to the recruiting office to enroll himself as a soldier of the Empire. On account of some errors in the paper which he presented it was returned to him for correction. That night in his room he sat with the paper before him which would renounce his home training, his country, his ideals, all that his life had meant, to become a German citizen. Then he remembered that the flag for which he proposed to fight was not his flag, that the cause was not his cause, and making his way through the lines he came home to Kansas with the paper in his pocket as evidence of the absorbing power of the German national mind. When this 
was possible with a Western boy, one may understand what it meant for a German citizen.

I am drawing my illustrations mainly from Germany because in no other land has the mind of the nation been so well organized, so definitely directed, nowhere else has the emotional ideal had such an overwhelming influence on the life of a whole people. Such has been the unifying effect of this ideal that even the demoralizing effects of defeat in the great war have not resulted in breaking down the union of States which was formed by force two generations ago.

So the great centripetal force in Germany to-day is the German mind. And the experiences of the war have brought out vividly the fact of the English mind and the French mind and the Italian mind.

It is the possession of the national mind that determines where citizenship belongs. We have thousands of men who are helping to elect our officials who are still thinking Irish, or English, or German. What we ask of the foreigner who lands at Castle Garden is that he shall become an American citizen.

What does that mean? Only that he shall go through certain legal formalities before a judge of the courts? We have certain elements of the population, which are obsessed with the idea of patriotism, that would line up everybody, especially school teachers, and have them swear to the Constitution of the United States as a panacea for all foreign ideas that may be abroad in the land. Not dissimilar was the spirit of Clovis, who marched ten thousand Germans into the river and baptized them at once into the Christian faith.

The fact is that men and women become American 
citizens as they get the American mind. They belong to United States when they think United States. It is not the acceptance of a legal formula that changes a foreigner into an American, but a change of mind. So we say to the foreigner who comes to our shores, "Let this mind be in you which was in Washington and Lincoln and Roosevelt," and when he gets the new mind he is an American. This is what Americanization means.

So America to them is not New York, or Chicago, but it is the national mind within them. One said to Maurice, "The Kingdom of God is within you." $\mathrm{He}$ answered, "Yes! so is the kingdom of England." England for the Englishman is not something outside of him. It is something inside. It is something that he carries with him wherever he goes. That is the reason why the Anzacs lie so thick at Gallipoli and in Flanders. Real citizenship is , not determined by residence but by an attitude of mind.

\section{Patriotism.}

This lays down for us the basis of patriotism. It means loyalty to the national mind within us. It is devotion to the national side of ourselves. It is as natural for the real citizen to love his country as to love himself. So when we sing

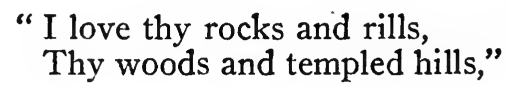

we are dealing with incidentals, not fundamentals. It has been said that wherever a Frenchman goes he carries Paris in his heart. That is where each man carries 
his country and he never realizes how large a place it has in his heart till he sees his flag ten thousand miles from home.

So patriotism is not under control of the police. It is not created in any degree by calling the stranger within the gates, "chink," or "greaser," or " dago." A man going along the street in one of our cities bought two apples and gave one to a workman whom he passed, putting his arm around him as he did so and saying, "I love you." That is teaching patriotism, for it is a step in human brotherhood.

This is not at all the patriotism taught by the Chicago Tribune when it carries at the head of its columns the saying of Stephen Decatur, "My country, may she always be right, but right, or wrong, my country." That is the sort of patriotism which covers injustice and fraud. Carl Schurz puts it better, "My country, when she is right to keep her right, when she is wrong to set her right."

\section{Nationality is the National Mind.}

The last century, especially the last few years, have been marked by the rise of new nationalities which are asking, and demanding a place among the older nations of the world. Some of these may be like

\section{"Voices crying in the night \\ And having nothing but a cry,"}

but for the present they are needing attention. What we seem to need is a definition of nationality. Evidently it is not decided by religious preference, for Protestant 
fought Protestant, and Catholic fought Catholic, and Mohammedan fought Mohammedan in the recent war with all the viciousness that might be demanded by a drill sergeant. Nor was it race, for Pole fought Pole and Jew fought Jew. Nor was it residence, for neighbor fought neighbor. Indeed, it seems as if all the old rules have been destroyed by the needed exceptions to them. Language seems to have had more to do with lining men up in a common cause than any of the things mentioned, for language is the expression of mind and a common language is likely to mean a common mind.

The thing that does seem most decisive is the emotional ideal. It is true that the Balkan peoples seem to be dividing frequently on race lines and that may be decisive in many cases of the ideal which calls out the deepest feelings. Nationality, like love, is a passion and it seems often as difficult to explain one as the other. But no one doubts the existence, or the power, of either.

"What is it makes a nation?

Is it States, or ships, or guns?

$\mathrm{Or}$ is it that great common heart That beats in all her sons?

That deeper faith, that truer faith,

That trust of one in all,

Which sets the goal for every soul

That hears his country's call."

When our soldiers went across the Atlantic they were in England and in France and in Belgium, but however they were treated these places were not home. Nothing could have made these places home except a change of mind. The people spoke a foreign language, but more than that they thought foreign things. All of our men would have 
agreed with the colored soldier who while coming up New York Bay past the Statue of Liberty took a long look at the uplifted arm and said, "Put down you' light, honey, I's home."

\section{Making Up the National Mind.}

Some have objected to the idea of the national mind on the ground of the divergent and contradictory ideas that are in it. But this does not seem to be a fatal objection since even the reader of these pages may have divergent and contradictory ideas in his mind. In fact, he has no little difficulty in deciding between these conflicting views. So if conflicting views in the national mind would be evidence of two or more personalities the same may be said of individuals. It would seem that if a man had only one idea, it might get lonesome and stray away looking for company and forget to come back.

The North and the South had conflicting ideas about human slavery and they had them for a long time. But they do not have them now. If they had two minds then, what became of them? What was really taking place during the slavery contest was the attempt to make up the national mind. It takes longer to make up the national mind than the individual mind, but the method is the same. Facts were presented by platform and pulpit and press, feelings were stirred, and finally the will of the people was written into the law of the land. Nobody has questioned for a half century that slavery is dead, nobody wants it back.

Then we spent nearly as long making up the national mind about the liquor traffic. Again we had the gathering of the evidence, the appeal to the emotions and finally 
the action of the national will that the business had reached that stage of decomposition that it should be buried. So as the verdict on slavery was written into the fundamental law as the final judgment of the nation, we have the Eighteenth Amendment, which is the verdict of the nation on alcohol. As in all such cases there are individuals and organizations which seek to nullify the national judgment, but what is written into experience and then into law abides. This is the process that is continually at work in the national mind, for great issues have no regard for the peace of nations. A score of questions are demanding settlement and zealous advocates are asking for the first place on the national docket. Processes of the National Mind.

Our psychologists tell us, what we might guess without the telling, that our mental operations are classified as intellectual, emotional and volitional, or, to put it another way, we have intellect, feeling, and will. And as far as we can see every mind will have these forms of expression. May we say the same of the national mind? Is there a national intelligence, and a national emotion, and a national will? That would seem to follow from the things we have been saying of the national mind, but may be worthy of investigation.

\section{Is There National Intelligence?}

Is there a way of thinking that is distinctly English, and another that is distinctly French, and another as distinctly German? Is it not evidence of that when nations, and citizens of different nations, are not able to understand each other? That failure to understand is 
the fruitful cause of individual quarrels and of international war.

One realizes this when he tries to learn a foreign language. It is not simply getting the foreign words in his memory, but to make these words express what is in mind. In fact a complete translation of one language into another is not possible because the things expressed are not the same. Not till one can think in the foreign language can he speak, or write it out perfectly.

An Englishman who recently lectured in this country said that a chief reason why the American and English soldiers did not get on well together was because they did not understand each other's jokes. He insisted that if men can laugh together over their troubles it will lighten the load. There is no greater test of our knowledge of a language than our ability to appreciate its jokes. Most of us have been puzzled with the English and the German joke as also they have been with ours. Most of us will admit that the Greek and Latin jokes that we came across in our college texts did not break up a recitation. As I recall the Homeric joke it was interesting chiefly because its frequent appearance made easier reading for a few lines.

The reason why the German universities arranged for the exchange of professors with our schools, the reason why Cecil Rhodes arranged for the scholarships for American students, was to get the respective countries to understand each other. Both plans were aiming at an alliance between the countries based on that most enduring foundation, a common intelligence.

If the nations are to develop their common interests into a lasting bond of friendship, it must begin with the 
knowledge that we think differently and must take this difference into account in international dealings. Even when we use the same language as the Englishman we often mean something that he does not. When an English boy speaks of "doing his bit," it is of what he owes to himself as a man; when an American boy uses the words he means what he owes to his country.

\section{Is There National Emotion?}

What I would like to make plain is that not only is there national feeling but that it is the dominant social force. This has been most evident in great religious movements, when the emotion of the ideal has lifted a nation to heights of sacrifice and attainment that otherwise would have been impossible. In such cases nations have shown themselves invincible against foes within, or without. Witness the struggle of Holland against Spain in the sixteenth century, or the rise of Puritanism in England a little later.

Perhaps no other nation has ever used the conception of the emotional ideal more consciously than has Germany. Mazzini had already urged on his countrymen that the ideas of duty and sacrifice furnished the influence, not only of the advancement of the nation, but of the world. Rights, he urged, had been the moving cause of separating classes and nation and that if the demanding of rights could be succeeded by the teaching of duties to the children of the nation and the world it would cement them together in a common life.

It was Germany that adopted these ideas as a dominant feature in her educational system. From the teachers of the common schools; the secondary schools, and the 
professors of the universities, came the steady urge upon the children and the youth of Germany to make duty to the fatherland and sacrifice for her interests the chief aim of life. The history of the land, its victories and its achievements were the daily thought of the pupils in the grades, her songs were on every lip. The wearisome barrack life, the grind of daily toil, was but the due of each citizen to the national ideal. Any one who recalls the speeches of the Kaiser will recognize this note running through them all.

The result in Germany is evidence of what may be accomplished in any land where the whole educational system is organized to propagate a certain ideal in the mind of the nation. In Germany it meant the dominance of German Kultur not only in her own borders, but through the world. But if the ideal had meant a passion for the conquests of peace instead of war, the emotional ideal would have been equally strong, only the outcome would not have been that of I9r8.

Germany has taught the world a lesson by which other nations should profit. As she was changed in little more than a generation, so may others be changed according to the ideal which lays hold of the emotions of the people. A people which would take the ideal of peace and righteousness as the center of its educational system, of its press, of its government, that would keep continually before the mind of the children and youth the duty of sacrifice for this ideal would organize the national forces for world conquest, as certainly as did Germany, only for the uplift of the world instead of its downfall.

Germany has taught the world the method. When a few men under the haystack at Williams proposed the 
conquest of the world for Christ it looked like the impossible; by applying the German method it would be practical. She has shown how national institutions and a national state may be changed in a generation. All that is needed is the setting of the sum of the educational forces of a nation to a given task, and teaching as a life duty to the citizenship the work of sacrifice to gain the end. Class feeling, race feeling, and national feeling have been used for destructive ends, but they may be the means of lifting a nation to a degree of heroic service for righteousness such as the world has not yet seen.

\section{Is There a National Will?}

It does not seem that any argument is required at this point in order to justify an affirmative answer. "The will of the people" has long been a common statement in popular speech and is universally accepted as a fact in political theory and practice. The American Republic wills the kind of government she will have, the policy which she will follow, the individuals who shall guide her affairs. The modern question is not whether the nation has a will, but whether this will has any limitations. Often the teaching runs that not only does the national will decide the national policy, but $\mathrm{as}^{*}$ well furnishes a final standard for the conscience of the citizen. Whenever military ideas and policy dominate in government policy, there is swift penalty for the one who dares think otherwise than as the public will decrees. Our own country was not without abundant illustration of this fact during and following the months of war. Liebknecht was given four years in prison for opposing the German government, while for lesser offences some in 
United States were given ten years. So one who recalls recent events will be in no doubt of the fact and the potency of the national will.

The idea that government exists merely by the consent of the governed is an instance of the survival of an old belief after it has ceased to have the semblance of fact. It is a relic of the ancient notion that government was in the nature of a contract between the rulers and the ruled. It saw in the people and the government independent parties, who dealt each with the other on terms of equality. But government is not an independent party in the case. It is the agent of the nation, is set up and directed by the nation.

The will of the nation is completed in the national acts. The intelligence chooses the policy, the national feeling furnishes motor power, the will unites the national mind in the completed act.

\section{The Nation is a Psychological Organism.}

The sociological writers have dealt with this subject so exclusively from the biological point of view and given such a biological bias to the terms used that one uses the word organism with some hesitation. But since the term is needed here it seems altogether a pity to surrender it to the materialists without, at least, a protest.

So we shall understand at the outset that we do not accept the biological conception of the nation, which holds that citizens are related to the nation as the cells to the body. The biological idea of society has some value as an illustration, but has little relation, even a poor relation, to the fact. The most tyrannical social order that the world has ever known still allowed a freedom to the 
individual citizen, which the biological view makes impossible. The military clique in Germany, and in Washington, go on the assumption that the people have no more liberty than the cells of the body and that it is the business of the citizen to stand attention.

But army life, like war, is abnormal. Its mechanical order is unsocial. Men are not bound together by the drill sergeant, but by the mental attitude which they take to the commonwealth. Professor Ramsey Muir has told us, "Nationality is an elusive idea, difficult to define. Its essence is a sentiment, and in the last resort we can only say that a nation is a nation because its members passionately and unanimously believe it to be so."

So the social organism is not a biological, but a psychological concept. Its citizens, like those of the Kingdom of God, do not lose freedom through sharing in the national life, indeed it is through being born into the social order that they attain to the reality of life. It is not claimed here that the nation realizes unity as does the Kingdom of God, or that the citizen realizes individuality as far as is possible to the citizen of the Kingdom, but what is meant is that both the nation and the Kingdom are psychological organisms.'

As was previously suggested the national organism is only in the formative stage. "For the national mind," says Fouillee, "is a continuous growth; it is not embodied in a temporary succession of individuals, but in a continuously developing organism." Only when the nation gets the Spirit of the Kingdom will it fully realize its nature. On its way to this completeness it has been said that each nation must pass through its Red Sea, as did Israel on its way to national life, a suggestion that 
only through suffering may the common mind, which constitutes a nation, be attained. "Society," says Fouillee, "is an organism which exists because it has been thought and willed, it is an organism born of an idea."

But the question may still remain as to whether the nation is really organic in its nature. Mackenzie gives to us the following definition of an organism: "An organism is a whole whose parts are intrinsically related to it, which grows from within, and which has an end suited to its nature." Does this definition seem to apply to what we have been calling the national mind? To answer this question we may use the three tests given by Mackenzie to social phenomena.

I. Are individual citizens intrinsically related to the nation?

Are they so related that the nation could not exist without the citizens, or the citizens in any real way without the nation? Do the citizens make the nation and the nation the citizens? The Greek word for the isolated, unrelated, man is our word idiot, since according to the Greek idea, it is only in his relationships that man really comes to life. Indeed we are all so dependent on our associations that solitary confinement is the most severe of punishments. A philosopher like Thoreau may take comfort in his seclusion at Walden Pond, but most men would prefer to "live in a house by the side of the road."

Any one who tries to change the course of a life will be impressed with the fact of intrinsic relationships. He finds his man among evil companions and he replaces them with good; the bad literature which he reads is ex- 
changed for that which is healthful; the man is given $\bar{a}$ fit occupation to engage his attention; then all the friendship that one can give is lavished on him. And what one learns when all this has been done is that only divine power can change a life, as Paul's life was changed, and set it going in a new way. If only a new birth can change a life, it seems evident that there are vital relationships that hold it in the course it has been following. Harold Begbie has furnished abundant evidence of the need for the supernatural to change a life.

The fact seems to be that the citizen and the community are each essential to the other and that each influences the other in proportion to the relative strength of character. Our truly great men proved their greatness by moulding their environment instead of being moulded by it. The nation would not be what it is if Washington and Lincoln and Roosevelt and Wilson had not lived their lives in it. But even they were its citizens and not the less that some of them were citizens of the world. Hampden and Pym could not have been without Puritan England and England's life would not have had all its virtues without them.

\section{Does the Nation Grow from Within?}

Referring to Alice in Wonderland by way of illustration, we may say that "ships and shoes and sealingwax" do not grow from within, while "cabbages and kings" do. Therefore the latter are organic and the former are not. No one can tie leaves on the outside of a cabbage and deceive even the wayfarer into the belief that the result is a part of the plant. The cabbage does not grow that way, neither does the king. But if 
one will give the plant soil and moisture and sunshine it will grow in the only way possible for a cabbage, from the inside.

Also there is a lesson here for statesmen which they may ponder with profit. Nations grow from the inside too. England and United States have tried the experiment of tying foreign elements on the outside with military and naval bandages, but the latest reports indicate that the East Indian and Egyptian have not become English, nor the Filipino an American. This does not mean that the attachment was not a good thing for the colonies, but it is plain that the grafting has been a failure. In fact police powers seldom make a lasting connection. Napoleon said that you could do almost anything with bayonets except sit on them, so the position of colonial governments is not comfortable.

One may graft a piece of skin on the body, but only when the blood of the body circulates through it does it become a part of the body. So we can not hitch foreign elements to us by any outward force as a permanent condition. Military domination does not give the foreigner our ideals and hopes and aspirations. We can assimilate the foreigner, not by police powers, not by our industries, not by our schools. He may have the discipline of all of these and remain foreign to us. But the human sympathy, which has been touched with the divine, so that it holds him a brother man, will break down the barriers of race and class.

\section{Does the Nation Have an End Suited to Its Nature?}

This seems evident to those who have given attention to national characteristics. Nations are as diverse in 
this respect as individuals. Each has its own type of mind, its own method of life, and its own destiny to achieve. England, France, Germany, United States, are as unlike as the citizens of which they are composed, each has its part to play in the great world drama of the nations. Some of these may fail to fulfil the purpose of their creator and will be put aside for more worthy successors, but this very disaster, which has come to many nations of the past, is in itself a proof of an end which each nation is to serve.

Now we have considered the three tests in Mackenzie's definition. Does not it appear that United States fulfils the conditions of the definition of an organism? Our Republic is a whole whose parts are intrinsically related to it, which grows from within and which has a destiny peculiarly its own.

National Responsibility.

One of the plain conclusions from the reasoning of this lecture is the fact of the moral responsibility of the nation. If the nation thinks and feels and wills, and I do not think that one may explain the phenomena of current history on any other supposition, then the nation is responsible for its acts as is the individual, is subject to the same influences for good and ill. In fact this belief is so universally accepted that it is in our common speech. One does not need to explain to the man on the street that Germany was responsible for the invasion of Belgium, that Belgium was responsible for the atrocities of the Congo Valley, that England was responsible for the Boer War and the United States for the Mexican War. No one questions these conclusions and they are 
justified only if the nation has a mind to reason and a will to choose. America is in good degree responsible for the defeat of Germany and if all plans fail to get a national agreement for the establishment of world peace America will in large measure be responsible for that failure.

Why have nations failed to meet their responsibilities? It is not so much because of enemies without as foes within. The old histories told us that Rome fell because of the invasion of the Goths, but we know that Rome was rotten at the heart and went down through its corruption. Idleness and vice destroyed the virtues of the Roman citizen and sapped the life of the nation. Poetry said, "Sarmatia fell unwept, without a crime," but history tells us enough of the tears and the crimes. Nations, like men, must reap as they sow.

Mackenzie's Introduction to Social Philosophy: Essays in Philosophical Criticism. Seth and Haldane; The Group Mind, Professor McDougall ; La Science Sociale Contemporaine, Fouillee ; Psychologie du Peuple Francais, Fouillee; Social Psychology, Ross. 


\section{SOCIAL INSTITUTIONS.}

IT is in the very nature of spirit to be active, therefore the State must have agencies through which to act. To some extent the social life expresses itself through individual members of the State, but its larger expression is through its institutions.

The individual enlarges his life as he increases his intercourse with his fellows and with the world about him. Take away his eyes and ears, his hands and feet, and his life can not be enlarged, even if it be sustained. His life is conditioned on activity. Applying the analogy of the individual to the State, it seems clear that the latter stands in equal need of channels through which the life may go out into action. It is to the institutiona! forms of the social life that the attention is here asked.

Even in the earliest and the simplest periods of the social life, some institutions were found necessary to its enlargement, and even its existence. From the first the Family had a place. Into it the individual was born and through the various Family functions, as then practiced, the State in embryo did the main part of its work. But as nomadic life was succeeded by the settled conditions of agriculture, and this coupled with manufactures and commerce, the social institutions multiplied to allow expression to the growing complexity of life. Each new situation demands a new institution, or the 
remodeling of an old one. The rise and growth of these institutions furnish the material of social history.

\section{The Family.}

The Family most fully meets the primary social needs. The patriarchal Family, which seems to have been the prevailing form in early times, suggests, in the functions which it performed, many of the later institutions which arose through social division of labor. Government is suggested in the position which Abraham held, especially when we find him calling together a small army out of his immediate followers to fight with the Eastern invaders. Within his limited domain, and among those who were his kin by blood, or the fiction of adoption, he ruled as a king. The will of the father was supreme.

The Family contains the germ of the school. The most rapid development of mind takes place before school age is reached and the bent of interest has been largely decided before the pupil enters the classroom. The teacher comes in to supplement the work of the father and the mother, having the possibility of enlarging the view of the child, seldom of changing the standpoint from which its world is seen. The prejudices of the home become those of the pupil and the man. The home life makes, or mars, the pupil of the common school and the scholar of the higher grades.

It is in the Family that the child gains his religious foundations. Whether, or not, religious instruction is consciously given to the child, it goes out into life equipped with a theology and a code of ethics. What 
the Church can affect in the later life depends much upon the conscious, or unconscious, teaching by the fireside. If the Bible is made the commonplace book for reference and story, if the catechism is made the recreation in which all share, not the task imposed upon the child as a punishment, there is laid a theological basis, a foundation of principle on which to build a solid life structure.

There is also seen in the Family the division of labor which makes the factory system the economic method of industry. In the home that is wisely guided each person has his duties, on the right doing of which the welfare of the Family depends. Thus is early begun the training in industrial efficiency and the more important training in the sense of responsibility for the welfare of others. The duties need not be arduous, should not be irksome, but it is necessary that they should be recognized as duties if the child is to be trained for social service. It is where this sense of other selfishness is not gained in the home that the kindergarten has its place in doing the work which is neglected in the Family.

The importance of the Family is doubly realized by those who have tried to deal with the homeless class, which is always a factor in the community. If a Family can be found to adopt the outcast the case is simplified, but in the greater number of instances this can not be done. It is to meet this social need that the orphanage is established to take the place of the Family relationship. Yet how imperfectly this substitution can be made is known by those who trace the later life of the child 
of the orphan's home. A clergyman who had spent many years in public institutions said that he had often followed the child from the orphans' home, through the reformatory, the penitentiary, and the prison. $\mathrm{He}$ said, as many others say, that good citizens are seldom made in the orphanage, yet society has devised no other institution that can take its place. This emphasizes the fact that each social institution has its special function that must be imperfectly performed by any other. In particular must the Family be guarded from every influence which diminishes its social service.

\section{Government.}

The Government is the social institution through which the State expresses its will for the control of individuals and other institutions. The earliest form of social control was exercised by the head of the household, but when the nomadic life was succeeded by the settled condition, the social control occupied too wide a range of actions to be administered by the father. From the earliest institution of Government as a separate social function it has persisted, though at times so inefficient as to have little value. This was the case in the Middle Ages when the collapse of the Roman authority left only the shadow of imperial control over the districts which it had ruled. In this and similar cases the administration reverted to individual hands.

When a freeman had a quarrel with his neighbor, since there was 110 convenient magistrate to whom appeal might be made, even if it had not been disgraceful to 
propose such peaceable means of settlement, he fought the issue out with clubs, if he was a commoner, with lances if a knight. Now two things are clear: that under such conditions good order could not be maintained, and that there would be a waste of social energy. Almost any kind of efficient rule is preferable to the economic waste of time and energy when each individual has to be both magistrate and policeman. When one set of men is given the work of legislation, another the function of interpretation of the law to meet the special cases presented, yet another given the function of execution, or even when these functions are centralized in a single class, the bulk of the citizens may devote their strength to other employments, with great gain to the social economy. When the workman builded the wall of Jerusalem, as runs the record, with the sword in one hand and the trowel in the other, the result in stonework would not be large.

This illustrates the fact that the social institution acts as a conservator of social forces, through the division of labor which it affords. By giving each group of men a special duty, it gives them the opportunity of becoming specialists in that work and so giving better service. It also sets free other men for other service. When every twentieth man is in the Government, as is said to be the case in France, and dependent on the Government for his support, it means a great social waste. In far larger measure is there social waste when nearly the whole body of citizens of a certain age is set to defending the fatherland against imaginary invasions. 
In civilized countries the army should have only police duty and if justice is followed in the administration of Government, police force can be reduced to a minimum. The large standing army is a proof of unsocial conditions.

\section{The Church.}

As the main purpose in this connection is to show that the social institution comes into being in response to a social need, it will not be necessary to treat each at length. The Church finds a necessary place because the social spirit, the State, has a religious character which demands institutional expression. This does not mean that the religious idea finds outlet through the Church alone, for being an element of the social spirit religion must have some place in all institutions which meet any legitimate social need. But it is through the Church, the institution which performs the ecclesiastical duties of the social spirit, that religion finds its chief expression. The religious factor will be found in Government, in Family, and in the factory; but as the economic is the chief factor in business, so is religion in the Church. No single institution has a monopoly of any function; it has some one function in greater degree than any other institution. Even the Church must deal somewhat in finance. Each legitimate social institution has a special social duty of its own, yet in each, since they arise from the social spirit, are found subordinated to the chief function, the suggestion of the functions of other institutions.

This religious factor which expresses itself most con- 
cretely through the Church, and in general way through all social institutions, comes into the social life through its contact with the divine life. The complete filling of the social spirit with the divine spirit would mean the transformation of all social institutions and the realization of the Kingdom of God. When Paul, in explaining the kinship of the social members, reminded his readers that each had his own particular gift and consequent duty and that through all worked the same spirit, he was teaching what I wish to make plain here. It is in this relationship that social institutions are to be understood. All are expressions of the same social spirit, the State.

It is evident that the man who argues that religion has no place in business and politics has a faulty psychology. No human spirit is devoid of religion, even though it may be a feeble influence. If there were no religious element in the State, there could be none in the Church, since the latter is an expression of the former. If there is religion in the Church, it must exist in some measure in all other institutions, since all are related. We do not go to a railroad company for religion, yet it must be present there. All are members one of the other.

The older social philosophy which proposed to split society into isolated fragments, even, as Kant taught, to divide the individual into what he regarded as the hopeless contradictories of reason and feeling, is not supported by the facts of individual and social life. Life is a unity and any philosophy of life which does not 
find unity as its basis, needs revision. This does not mean that there are not conflicts in life between opposing principles. Such contests are ever present, but there is a life which includes both parties in the struggle. Nor does the fact of social unity preclude a higher moral standard in one institution than in another. The Church sets a higher moral standard than the trust company, since the former is made up of the best men of the community, while the latter demands no other qualification than business shrewdness; yet while both institutions have the same leaders as is frequently the case, we should not expect the principles on which the two institutions are administered to differ essentially. In such case the Church might be expected to have something of the character of a social club, with some insurance features included. Politics can not be depraved and the Church pure in any community. The idea that the Church can be isolated from the life of the time was not realized even by the monks in the Thebaid, much less in modern times. The Church can not be on the road to heaven and the corporation on the way to hades, when the same people are in both institutions. If selfishness rules in the market it can not be barred from the fireside. What is present in marked degree in one phase of life will be present in some degree in all others.

Some idea of the way in which a social institution originates, and of its relation to the life of the community, may be gotten by recalling the incidents connected with the settlement of Oklahoma City when the Indian lands were opened to the "rush." In the morning the 
site was uninhabited prairie and before night it had a large population with an organized Government. The immediate need for this institution is evident when we recall the situation. The settlers were largely made up of the less tractable class, who were ready to enforce their arguments with the revolver, so that when several squatters laid claim to the same desirable lot on the prospective main street, there were liable to be some unlawful methods in the proving of the claim. In order that the various claims might be submitted to the courts for settlement, it was of the first importance that a form of Government should be established with authority to keep order among the sadly mixed crowd. Under such conditions the organization of Government will be among the first actions of the community.

On account of the rapid transfers of real estate and other salable property, some institution was needed to conduct the financial operations and a bank was established. Now it is doubtless true that both the Government and the bank had been planned in advance by a few individuals, but these individuals only anticipated the social need. They did not create it. The social life found expression through the institutions named. This leads to a conclusion, which the State must come more thoroughly to understand, that a social institution, offcered by individuals, must still minister to the social welfare. They are at least semi-public officials and public office is a public trust.

If the administration is to be left in individual hands it must be on condition that these individuals recognize 
their obligation for social service. There is no more reason, in the nature of the case, why the bankers of Oklahoma City should run their business with sole regard to dividends than that the officials of Government should do the like. Here lies the demonstration of the principle previously stated that the factor which is dominant in one institution will inevitably present itself in others. If the railroad company, a social institution, is to be run simply for the holders of its stock, why should Government not be run for the holders of office? That it is so run in many instances is evidence of the fact that corruption will not be barred from politics until all social institutions manifest a new spirit of social service. If the Sugar Trust may with impunity disregard social interests in the making of its schedules, may not Congress do the same in the framing of law?

As the population of the town becomes acquainted with its religious conceptions and need, there is a demand for the organization of a Church. The first organization will be of that creed which expresses the religious cravings of the larger number of the inhabitants, that is, the social needs will be satisfied in the order of the intensity of the demand. In some districts of the West, and of the East as well, there are large populations centered in mining camps where there is no demand for the Church. This does not necessarily mean that the persons gathered in such localities have no religious interests, but it means that these religious interests do not bulk large enough to demand expression through an ecclesiastical institution. At the same time they will foster 
institutions which some other neightborhood would not tolerate. In each community are found the interests that are in others, but in some the interest is not great enough to demand any form of organized expression. When an agent is sent by the Church into a community where there is no ecclesiastical organization, it is with the purpose of awakening the religious interest to such a degree that it will require an institutional expression. The town will not have added many months to its life before there comes a demand for schools. If the people are far scattered, as often on the prairie, the instruction must for a time be given in the Family, but the increase of population enables this social demand for a school to be satisfied. At first the building will be crude and often both teaching and teacher of a like order, but with the possibility of better things, a change ensues. The shed gives way to a commodious classroom, the high school is added and the institution develops in accordance with the latest models. Institutions are an expression of the social spirit and they develop or decay in correspondence with the spirit which works through them.

While it is the social spirit which gives rise and character to the institution, there is a reciprocal relation between the institution and the life behind it. Radical and permanent reforms involve changes in the social spirit, since such changes affect all institutions. But a change in the institution also has its reflex influence upon the life. A change in school methods which gives new interest to the pupils, affects the whole life of the 
community. An improvement in the mail service results in bringing social elements that had previously been isolated into communication. 'A better street-car service relieves the congestion in the crowded centers of population, making life more tolerable for the poor. Every one of these changes has its effect on the life of the people. Thus reforms are brought about directly by changing the social spirit; indirectly by changing institutions.

This conclusion shows the part which the Spirit of Jesus Christ must have in all deep and lasting social transformation. It is as the divine Spirit is projected into the State that all institutions will gain new impulses toward better social service. While the social institution has its inspiration from the social spirit, this, in turn, gains its aspiration from God. 


\section{CHURCH AND STATE}

Whenever it is proposed to place any religious feature, such as a Sabbath law, on the statute book, a cry of alarm is raised that the proposition means a union of Church and State; yet if the alarmist was questioned as to what he meant by Church and State respectively, his sorrows would increase. But his fear is not altogether causeless. Something was realized in the past which has been called a union of Church and State from which came very undesirable results, so that if the charge of such union is fastened upon any movement, it has the effect of original sin, since the movement is condemned even though actual transgressions are not proved. It is necessary in any discussion to define the basis on which it shall be conducted, and specially in this case where there is such variety of opinion in regard to the meaning of the terms.

The definition of the State which is followed here, is stated in the first chapter. It will, therefore, be sufficient to say that the State is the social spirit. The State, or social spirit, being subjective, must find expression and perform its functions through objective institutions such as the nature of the State requires. In the chapter on Social Institutions, the necessity for their existence is discussed, also the fact of their necessary correspondence with the life which they express. It will 
scarcely be questioned that the Church is one of the most important of these social institutions. The social spirit is religious by its nature, since every race that is known has some form of religious worship. Those who would prove the assertion that religion was foisted on men by priests for their own selfish interests, would need to have the priesthood precede the existence of man on the earth, as he has always shown his religious inclinations.

The Church exists as the most concrete expression of the religious nature of man. The time when the Church appears in human history is not a point which is of importance in this chapter. It is sufficient for our purpose to notice that it has been one of the great social facts with which every student of social forces has been called to deal. In speaking of the Church as the institution which expresses the religious nature of men, it is not meant to imply that this nature does not express itself through other institutions. Since the social life is organic, each part is related to every other. Thus the religious factor, while the dominant characteristic of the Church, is present in every phase of the social life and, therefore, in all institutions. This is illustrated in the life of the individual. As a Christian, he will make the Church his chief agency for putting his religious beliefs into practice, but as a Christian he will give evidence of his religion in his shop and his store. If his religion is of the kind that only serves for Church purposes, its quality may be open to some question. So is it with religion in the social life; it permeates 
the whole life and, therefore, all social institutions. Relation of Church and State.

If the definitions offered be accepted, the relation of the Church and the State are easily understood. The Church is the concrete expression of the religious phase of the State. Whether the State is definitely Christian, or Mohammedan, or Hindoo, the Church is the expression of the dominant religious idea in the State. According to this view, we could not consider the question of a union of Church and State, nor, by correct definition, has such a thing existed, unless in the ancient societies. The fact is apparent that the reputed union of Church and State, which is so often and so justly deprecated, involves a different conception of the State than that given in these pages. It is based on the old, discarded idea that the Government is the State. Of a union between the political government of the State and the administration of the Church, history, medieval and modern, furnishes many instances ; indeed, most of the countries of the world are trying the experiment of uniting the political with the ecclesiastical functions of society. In Germany, the Government has taken the Lutheran Church into alliance with it, in France the combination is made with the Catholic, and in England with the Episcopal Church. This union was brought about in each case by the action of the political institution, the Government, and is subject to modification by it at any time. The Episcopal Church in England might be disestablished by an act of Parliament. These two 
institutions, the Church and the Government of England, are so far united that the political and ecclesiastical functions are blended, the Government appointing the officials and enacting the creed of the Church. The Thirty-nine Articles which make up the Anglican creed were passed as any other measure in Parliament.

Admitting the view that the Government is the State it is permissible to speak of this relation being a union of Church and State, but not otherwise. By whatever name it is known, it is an unwarranted uniting of functions that ought to be allowed to work independently. It is in independence that political and ecclesiastical institutions will best work out the social end. Co-operation there should be in the uplifting of the people, but this means that each should act within its own sphere.

Disastrous Results from the Union of Functions.

No matter whether, as in the Middle Ages, the ecclesiastical dominated the political, or, as in the present day, the political imposes its requirements upon the ecclesiastical, injury is done to the State. Whatever lessens the real freedom of the individual, works social damage, and all the persecutions which paralyzed the Spanish people and blighted France, in and since the Reformation, came from the uniting of these social functions. Henry Eighth of England, because of his assumption of headship in the Church, decreed death to the Catholic who denied this place to the king, and also to the Protestant who denied transubstantiation. The Covenanters of Scotland were hunted as the quarry 
on their native hills, because they claimed that Jesus Christ, and not some Stuart king, was head of the Church. Neither Parliament nor Congress should dictate the creed of the Church.

Why Political and Ecclesiastical Functions Have Been United.

If this confusion of social functions, which were intended to co-operate, but not to combine, had been realized in but a single country, or in a special period, it might be passed with little notice, but since the instances are so numerous an investigation should reveal some common cause. Priest, or king, must have some end to gain.

Previous to the coming of Christ, and outside of the Hebrew Commonwealth, there was scarcely any distinction between the Church and the Government. The Twelve Tables at Rome dealt, without distinction, with ecclesiastical and political matters, and the pontiffs, who aided in developing the Civil Law from these Tables, were not lawyers but priests. Each Government official was an ecclesiastic as well. In Greece, even after the king had lost his political power, he was retained in office on account of his ecclesiastical duties, which only one of the royal line might perform.

The Roman consul on a campaign consulted the auspices, through which the gods were thought to reveal their will, as if he had been a priest. Under such conditions, a separation of the political and ecclesiastical was not considered. 
But with the coming in of Christianity, the situation changed. Something now appeared in the State, which had not been known before. It was a conflict of religions, between which religions the Government had to choose. This came to an issue in the time of Constantine, when the pagan faith had lost its power to bind Society together, and there was needed some new agency to support the weakened Government. To those who believe Constantine to have been a devout Christian, no other reason than this need be advanced for his making Christianity the Government religion, for certainly it was not the religion of the Roman State; but historians are inclined to view his action as having the political end of gaining for the support of the throne that compact body of Christians, numbering probably less than one-tenth the population of the Empire, whose enthusiasm more than compensated for their lack of numbers. The Christian Church was doubtless the strongest social organization of the age, and the Emperor wished to use its fresh blood to vivify the flaccid veins of a decaying order. The heathen had the weight of numbers, but Constantine judged wisely that the faithless multitude is a weaker social force than the compact body of enthusiastic believers.

From the standpoint of political expediency the establishing of the Christian Church by law was justified, but the effect upon the Church of making it popular, was to bring into its membership that class of men, too numerous in every age, who make popularity rather than principle the rule of life. $U p$ to this time, the 
members of the Christian Church had come through tribulation, but now membership was the road to political preferment. From this time we may date the decline of morality in the Church, which decline made Protestantism a necessity in the later time.

The same motives which led Constantine in the fourth century, actuated Clovis in the fifth. By accepting Christianity and baptizing his army of wild Franks in a body, Clovis won the blessing of the Pope and the support of good Catholics wherever his army moved. It was though the aid of the Church that he won his conquests over the wide territory which took the name of the conquerors, and it was through the same means that he bound the conquered together in submission to the $\mathrm{Me}-$ rovingian line of kings. It was with the Frank as with the Roman. The need of strengthening the Government caused the institutional union of Church and Government.

During the medieval period the rulers of the Hohenstaufen dynasty waged a long warfare to free Germany from the papal power, being compelled at last to make inglorious submission at Canossa to the Roman pontiff. With the single exception of England, protected by its insular position and the stubborn Norman kings, every country of Western Europe made submission to the Pope in the eleventh century. Now it scarcely needs argument, that if the other Governments of Europe had been as secure as the English kings they would have shown like independence, though even England had the Catholic as the established religion. Thus 
again it is Government weakness which furnishes the explanation for the uniting of ecclesiastical and political functions.

Nor is the case different when we recall more recent historical incidents.

When Henry Eighth dethroned the Pope of Rome, to set up the Pope of England in the person of the king, it does not require any inspiration to divine the cause. The divinity which doth hedge about the king when he is able to claim a species of adoration, aids in binding the people to the throne. It was upon the sacredness of the crown that the Stuarts depended to sustain them in power, regardless of the popular judgment which was passed upon the injustice of their administration. Whether the sacredness which may be thought to belong to Edward Seventh as the head of the Established Church gives strength to the present English Government, his subjects can give the most authoritative answer. Be that as it may, history seems to bear out the statement that the weakness of Government has been the cause of the alliance between the political and the ecclesiastical functions of the social spirit.

Religion and the State.

As has been already stated, an established church is not to be desired; indeed, it has worked no little damage in the past. But in opposing such conditions, some of its antagonists have gone to the opposite, and equally untenable, extreme, in claiming that religion should have nothing to do with political and business relations. It is 
probably true that one of these extremes is the natural result of the other, but the wiser conclusion lies on the middle ground. If it is true, as anthropology and the Bible clearly teach, that man is religious, then religion must find expression through his whole life. It is only a question of what the religion will be. The State will express its religion, whatever it has, through its whole institutional life. It is idle to talk of excluding religion from one sphere of the social life, while retaining it elsewhere. If life were not organic, such a conception might be conceded, but in an organism each part cooperates with every other. Grant that the social spirit is religious, and it inevitably follows that the Government, the expression of the State, will be religious.

Ecclesiasticism in Government is to be decried, but the Christian religion in Government will enable it to deserve the devotion of the citizen. It is loose thinking which fails to distinguish the Church from religion, an institution from a principle. Putting the moral law in Government would not join the Government with any Church, because the moral law is a principle. The things which can be united belong to the same sphere, and while the principles of the Bible should find expression in governmental action, we could not reasonably speak of uniting the Government with the Sermon on the Mount. On the other hand, the strength which would inure to the Government, which takes as its standard of justice the Word of God, would obviate the unfortunate mingling of ecclesiastical and political functions posularly known as the union of Church and State. 
There is no surer method of preventing this Old World condition from being reproduced in the New than in making religion an abiding factor in Government. In such case the Government can appeal to the conscientious loyalty of the citizens, and not appeal in vain. The Union of Church and Government.

Whenever one proposes a law to protect men from, working on the Sabbath; whenever it is proposed to legalize the reading of the Bible in the schools, indeed almost any Christian reform meets with the objection that it is a union of Church and State. It is worth seeing what this frequent cry of "Wolf!" means. In order to understand the issue it is necessary to see what the term "Church" means in this connection. We know what the Government means without explanation. There are five meanings of the word Church in common use:

I. We speak of the invisible Church when we mean the redeemed Society which makes up the body of Christ.

2. The term is used to mean the whole body of professing Christians.

3. The word Church is used when referring to a congregation of believers having a stated place of meeting.

4. The term is used in designating the building in which a congregation, or society, meets.

5. Its most frequent use is in reference to a body of believers united by a distinctive creed.

Now it needs no argument to prove that the union of Church and State, to use the popular phrase, does not mean a uniting of the Government with the Church as defined in any one of the first four ways. It is not a 
union with the body of the redeemed; it is not a union with the whole body of believers whose names appear upon the records of the Church; it is not union with a congregation; still less with a building. There remains, then, only the fifth use of the word which need be considered in this connection. The dreaded union of Church and State, more correctly Church and Government, is between a particular denomination and the Government. But this same conclusion is reached by another method. When one turns to Europe for illustration on this question, he finds the Government of England united with the Episcopal Denomination, the Government of Germany united with the Lutheran Denomination. In neither of these cases could the word Church be used in any other sense.

Now the practical question is reached, as to whether there is any reasonable apprehension that a law which forbade the discharge of a workman for refusal to work on the Sabbath would effect the dreaded union of the Government with the Presbyterians. What denomination would such legislation favor?

Or, to vary the illustration, suppose that an amendment was placed in the Federal Constitution acknowledging the authority of Jesus Christ and the supremacy of His law in moral questions, would that unite the Government of the United States with some denomination? If this question is answered affirmatively, what denomination would then become the established Church?

Is it not clear that the union of the Church with the Government, which is here deprecated, and the making 
of the teaclings of Christ the ethical standard of Government, which is here advocated, have nothing to do with each other? An established Church does not bring Christian principles into Government, though it does bring political methods into the Church. The Parliaments of England and of Germany are under no more obligation to legislate or judge in accordance with Christian principles, than is the Government of the United States. Bringing Christianity into political action does not bring in the Church; establishing the Church does not bring in Christianity. It would seem that the popular apprehension in regard to religious features in our laws, is due to a failure to understand the history of the subject and the terms used.

The Government can aid the Church, not by a merging of functions, but by co-operation. Both rest on the same fundamental constitution, the law of God; both have the same end, the uplifting of humanity. In rejecting the union of the Church with the Government, it is neither necessary nor wise to throw away religion with it. In our haste to throw out the bath-water it is not wise to cast away the child.

It will bring this discussion to a fitting close if we are able to make clear in what a union of Church and Government consists. There are certain facts always present in such cases, and by these familiar marks the union may always be known.

Three of these marks are always present where there is a Church established:

I. The Church is not independent of the Government 
in legislation. In England the creed of the Church is enacted by Parliament in the same way as any other measure which becomes a law. The Thirty-nine Articles which compose the creed of the Church of England were enacted in the time of the Tudors, and can be changed only by the English Government. The Church, as such, has no more control over the matter or form of her creed than over a land law. Members of the Church may be in important political positions, and thus bring influence to bear in the framing or amending of a creed, but their action is not as members of the Church, but of the Government. During the Middle Ages the Governments were often compelled to submit their measures to the Church officials for approval, but in modern times the Church has the subordinate position in the union. Whether the Church takes its constitution from the Government, or the Government submits its measures to Pope or council, there is not independence in legislation.

2. There is not independence in the choice of officials. In the time when the papal power swayed the political as well as the ecclesiastical destinies of Europe, it was necessary that the Emperor should have the endorsement of the Pope before he could consider his throne secure. But in recent times the interference comes from the other party in the case. Instead of the Church assuming to pass upon the political candidates, the Government chooses the officials in the Church. The Archbishop of Canterbury, the highest official in the Church of England except the king, has his place conferred upon him by the party which has the majority in the House of Commons. 
acting through the Prime Minister, as truly as does the Secretary for India.

Church officials are appointed by the same power and in the same way as the Government officials. If the Prime Minister is High Church in sympathy, as is the case with Lord Salisbury, the bishops who are appointed will, for the most part, incline to Ritualism. From the standpoint of an outsider, it is simply a matter of politics. Edward Seventh has as much control in the Church as he has in matters of political administration. The union of Church and Government has not succeeded in bringing religion into politics in any degree, while it has brought the Church catechism into the schools. From the facts which are apparent to all, it is evident that where such conditions exist there is no independence in the choice of officials in the Church.

3. There is not independent means of support. In America we are accustomed to the practice of each congregation, provided it has ability, supporting its own minister, while the Established clergyman draws his salary from the general taxation. These taxes which go to the support of the Church Establishment are collected from all the people who have taxable property, regardless of their belief. The clergyman is a Government official, and receives his salary as such. The Church may raise money from its membership for missions or other work, if it sees fit, but the clergyman is not supported by his congregation, nor is he responsible to it.

To sum up the preceding points, we have a union of 
Church and Government when there is a lack of independence in the framing of law, in the choice of officials, and in the means of support. It is equally true that where these conditions do not exist there is not a union between the political and the ecclesiastical institutions.

With this statement of familiar facts it seems clear enough that the putting of religious features into Government law and practice, and the other question of the union of a certain denomination with the Government, are entirely distinct questions. The gaining of one condition is not even a step toward the other, but rather away from it. The Government of England, with its Church Establishment, is scarcely nearer to Christian methods of administration, than is the Government of the United States, which is non-religious by profession. It would seem a fair conclusion from logic and history, that putting religion into the Government would keep out Church Establishment. Surely the man who, when it is proposed to place some of the teachings of Christ in law for the guidance of Government, feels it necessary to lift his voice in warning against a threatened union of some denomination with the Government, is somewhat afflicted with mental astigmatism. The simple question which would indicate how needless is his warning is the query as to what denomination would be united with the Government by such a measure.

The Kingdom of God, Herbert Stead; The State and the Church, Prall. 


\section{THE STATE AND THE INDIVIDUAL}

Ever since the struggle began between the rulers and the ruled, the philosopher in the sphere of theory, and the statesman in the field of legislation have been trying to adjust the relations of the State and the individual. The philosophers have outlined what they thought to be the ultimate social ideal, so that in the philosophy of any age we find what the ablest thinkers conceived to be the supreme social need; in the laws of the time is written what the lawmakers contrived to meet the immediate social needs. - It is in this way that the dreams of the idealists later find embodiment in the statute books and social theories direct the course of political action.

In the first chapter an attempt was made to define the State in psychic terms, together with some contrasts between the definition offered and those proposed by Mr. Spencer and Thomas Hobbes. In this connection a brief statement is offered of the views of those who have made the largest contributions to social philosophy, so far as their views are concerned with the conservation of social unity and individual freedom.

The Work of Moses.

It is in the legislation of Moses that we find the earliest recorded attempt to gain unity and freedom. When this great leader was assigned his task, the Israelites were a 
race of slaves, in servitude so long that they had lost their love of freedom; with a tribal formation, but an intertribal jealousy which stood in the way of the realization of national life. Under such conditions it is evident that unity under law is the first necessity, which must precede any lasting development of individual freedom. Moses recognized that order is the mother of liberty, not liberty the mother of order as the philosophic anarchist teaches. What Moses demanded from the loose tribes which he sought to fuse into a nation, was obedience to law, the first lesson of every people that has passed out of the rudest form of social life.

To develop an enduring patriotism in this disorganized mass of individuals, trained to servility and selfishness by centuries of slavery, was the task which fell to this Hebrew statesman, and the evidence of his wonderful success is the cohesion of this unique people through thirty centuries of suffering. So low was their conception of the priceless gift of freedom, that they would readily have bartered the free life of the desert for the old slavery of Egypt with the leeks and garlic of the Nile. One might search far for the negro in our land who, once a slave, would be willing to go back to the old life; yet this was what the Hebrews wished to do. Surely it was an inspired genius that could mould a nation out of such unlikely material.

The Israelites began their national life under the guidance of Moses. Mr. Herbert Stead holds that the Hebrew nation was formed about three ideas: the idea of God marked by the name Jehovah; the demand that those 
who worshiped Jehovah should have no other object of worship, and the personality of Moses himself. These ideas, accentuated by the central place of worship in the tabernacle, and later at the Temple, where they must appear three times a year, gave to the Israelite the unity necessary to growth.

But while all these aids to unity were in evidence, individuality had consideration. Slavery was abolished within the racial group, and its worst rigors forbidden in their dealing with aliens. The agrarian laws were so devised that the family estate could not be alienated, nor a monopoly in land created, thus securing to the Hebrew peasant a place not afforded by any other civil code. Carefully were the provisions drawn that the rich might not encroach upon the poor, the employer impose upon his servant, the ruler upon the ruled. The freedom of the individual in the older Societies may be tested by the place given to women, and in no other community of the ancient world did women hold the place accorded in the Hebrew State. While the Roman wife and daughter were slaves of the father of the family, they had legal rights among those who practiced the Mosaic code.

Plato and Aristotle.

From the point of view of individual liberty, Plato and his pupil Aristotle may fairly be classed together, for though the pupil differed from the master in method of treatment, there was general agreement in the substance of teaching. Both lived in an age when the prevailing social divisions by cities and classes made them look upon 
social unity as the chief end to be gained, and though Aristotle in particular sought to balance the spheres of authority and liberty, it looks to modern eyes as if he unduly emphasized the side of law in his theory. To Plato the State was the unit, the individual the fraction; while Aristotle modified this view in his argument, the individual bulked small in his conclusions. In neither philosophy did the State comprise more than the city, though there appears a longing for a unity of the Grecian race. Plato was the more theoretical, Aristotle the more practical. The fundamental principles laid down by the latter have colored nearly all later social theories.

Qualifications for Citizenship.

Both philosophers conceived of the community as divided into social classes, not by artificial arrangements, but by nature. The citizen class was made up of the warriors, the administrators, and the priests; the first class having the duty of defending the State, which was the city; the second, of dealing with its political affairs; the third, of performing the religious rites. Below these classes were the peasants and the artisans, who, while not slaves, were not considered qualified for citizenship. They performed their function by supporting the other classes, who administered the affairs of the State. It was not thought advisable to pass from one class to another, since each was born into the station which he occupied and was not fitted for any other. Each got his status by his birth, and it could not be changed without social damage. Thus only a small part of the popu- 
lation could be actual members of the State, though they were all under its control.

\section{The Idea of Slavery.}

The individual slave, as the individual in any class, got his position by nature, and to quarrel with his condition was to violate nature's laws. The slave did not count as a man, was not an end in himself, and according to the theory advanced, five of these menials should be assigned to each citizen, so that the citizen might be free from anxiety for his support, and be enabled to devote his whole time to the social concerns. The slave was but a tool for productive purposes. Nor was the line drawn as in modern times on color, or race lines; the debtor, or the captive in war, found his place in the slave system of the ancient world.

The Greek philosophers had great regard for the individual, going so far as to claim that the making of the most virtuous individual was the end of the State. But this applied solely to the higher classes, not to the individual as such. The rank of the man was decisive of his value. When one remembers how small a fraction of the inhabitants of the Grecian city were citizens, he realizes how little they had of democratic institutions.

About the time of Aristotle it is estimated that in Athens, a district smaller than our Rhode Island, there were eighty-four thousand citizens, forty thousand aliens, and four hundred thousand slaves. Aristotle has left the record that there were in the Island of Aegina, but little larger than a Western township, four hundred and 
seventy thousand slaves. Against such conditions the best men made no protest. Demosthenes inherited slaves from his father; Xenophen suggests that the State should work slaves for its own profit, while Cato the Censor esteemed a model husband and citizen - was a veritable Legree in the treatment of his human chattels. With such facts in mind, it is evident that Plato and Aristotle, who justified slavery, put too low an estimate on the value of individual freedom. With Plato in particular, who took Sparta as his ideal, the individual existed for the State; Aristotle, inclining to the Athenian views, gave the individual a somewhat larger place.

The Family and Property.

On these matters Aristotle differed with his teacher, who held that both should be in common. Plato insisted that social unity could not be gained so long as the citizens had any other object of devotion than the State. So long as the citizen had his own wife and children, and private property was the order of the day, so long would each citizen be devoted to the interests of his family, to the detriment of the State. To get rid of this social danger, as Plato thought it to be, he proposed that families and property should belong to the community instead of to individuals, thus destroying the selfish interests that interfered with patriotism. Perhaps no other phase of the teaching of Plato showed more clearly his willingness to sacrifice the individual to the community than this radical communism.

Aristotle did not go so far as Plato, though he did 
oppose the commercialism which would make gain the chief end of the citizen. Indeed, trade and commerce were looked upon as degrading in their influence, so that such work was left to aliens and slaves. It was in order to discourage trade that Sparta made her coin of iron, so that its bulk would make it impossible for anyone to carry much money with him. The price of a horse would have furnished the animal with a load.

The principle of the Greek philosophers, to which men went back in the reaction from the individualism of the eighteenth century, was that the State is in the nature of man. The individual found his life in the State, and outside of Society man had no more existence than the hand when it is cut off from the body. In this, Greek thought furnished the basis of modern philosophy, though it failed, on the other hand, to see that whatever restricts individual freedom must stand in the way of social unity. In their quest for a firm basis for authority, Plato and Aristotle too much lost sight of freedom.

\section{Rousseau and Individualism.}

When the Renaissance took up again the studies which had been interrupted by the irruption of the German tribes, Aristotle resumed his place as ruler in the empire of thought. But before the end of the Middle Ages there were many signs of rebellion against his domination. Nominalism came in with the claim, as against Realism, that the whole, instead of absorbing the part, as Plato had been inclined to hold, was only a name. It 
was the part that had reality. Applying the theory of Nominalism to the social problem, it meant that the Church, or the State, existed only as a general term, and that the individual was the only reality. The practical aim of this theory was to call in question the authority of the Pope and the king, for since Church and State were only names, they could confer no supreme authority on their rulers. The individual alone was real; he alone had authority. Thus in passing from the philosophy of Plato, to that of individualism, we have changed the emphasis from the State to the individual. The former held that the State was of supreme account, the individual but a fraction; individualism insisted that the individual was all, and the State an artificial product of a contract.

As the purpose here is only to show the relation of individualism to the unity of the State and the liberty of the individual, it will not be necessary to deal with the various exponents of the theory from Grotius to Kant. It is sufficient for our purpose to note that the eighteenth century was the period when it dominated theory and practice, and that Jean Jacques Rousseau was its high priest. While the idea itself was as old as philosophy, it remained for Rousseau to put it in such form that it became the topic of the man on the street, and roused him to a practical application of the theory.

Rousseau started from the premise of Hobbes, and of the whole line of individualistic thinkers, that man first lived in a condition of nature, which preceded society and law. Rousseau, however, differed from Hobbes, in 
that he taught that this natural condition was not so very bad after all; indeed, it was much better than that experienced under the Bourbons of France. Men escaped from the state of nature, as Hobbes had said, by an agreement, to which Rousseau gave the name by which it has since been known - the social contract. From this point Hobbes and Rousseau take radically different roads, Hobbes contending that any form of Government was better than revolution; Rousseau preaching revolution against all existing forms of Government. It is, therefore, to Rousseau, rather than to Hobbes, that we must look for a logical exposition of individualism, since it was the whole aim of the latter to establish an absolute authority.

Rousseau's Idea of Citizenship.

The social contract was a purely voluntary act on the part of the individuals who bound themselves by it; the individual who declined to take it, even though he was the only dissenter in the community, remained outside of the society which was formed. Over such an individual the society had no authority, since the law of nature, which each man possessed, made it necessary that each individual should consent to every act which concerned him, else it might work injustice to him. Nor was this idea set aside when society was formed by the contract. It was still necessary that each social act should have unanimous consent before it could be done. Nothing must be allowed to encroach on the freedom of the individual. Government must depend on the free consent of each individual governed. 
How, then, would Rousseau deal with the minority. on political questions? How provide that each man would have his will carried out, no matter which way the issue was decided?

His answer to this difficulty is more ingenious than reasonable, but it goes to show how persistently he defended his proposition that the individual should be free, by which he meant, without restraint. Rousseau said that when the citizen cast his vote on any measure - for all measures must be passed by the free suffrage of the citizens - it was not his opinion for, or against, the measure which he expressed. What he voiced was his opinion in regard to what the people wanted. For instance, if a matter of taxation was the political issue, the citizen would vote that in his judgment the people wanted the tax, or did not want it. If the majority of votes was against him it would show that he was mistaken as to what the people wanted, not that he did not get what he wanted himself.

Rousseau's Idea of Government.

According to Rousseau, the Government had only executive functions, legislative and judicial powers remaining with the people. The people in their general assembly, which included all citizens, enacted and interpreted all laws, leaving to the Government which they set up the sole duty of administering the laws prescribed and defined. Beyond this function Government might not go without infringing on individual freedom, a result always possible, said Rousseau, if the enactment and 
interpretation of laws was given over to any man, or set of men.

When the general assembly of the people comes together for business, the first proposition to be considered is whether the present Government shall be continued in office, and even if this question is not actually passed upon, it is understood that the existing administration is tacitly approved. Before this general assembly must come all measures which it is desired to formulate in law. Rousseau argues that the delegation of the lawmaking power to Government officials, means the enslavement of the citizens, and so he held that Englishmen are free only from the dissolution of one Parliament till the election of its successor.

These glimpses of the ways in which Rousseau followed out his individualistic premises, show the emphasis which he placed on freedom at the expense of social unity. While Plato had proposed the abolition of families, and private property, for the sake of social unity, sacrificing individuality so far as to call out the criticism of Aristotle that Plato was like the musician who sought for harmony by playing on a single string, Rousseau sacrificed order for freedom.

\section{Rousseau's Common Will.}

If consistency is a jewel, it was certainly one not worn by Rousseau. In his writings he marked the climax of one thought movement and the initiation of another. If, on the one hand, he gives us the most radical individualism by setting forth the individual shorn of all 
social institutions, unrelated to his fellows, uncuntrolleu' by any will higher than his own; on the other hand, he suggests the work of Hegel and the organic philosophy, by his proposition of the common will, even going to the extreme of proposing an Established Church, to whose creed each citizen must subscribe under penalty of banishment. After having premised that each man was unrelated, complete in himself, Rousseau said that the common will belonged to all, being the common element in all individual wills. It was found, he said, by cutting out of the wills of the individuals making up the community, that which was peculiar to each individual, leaving only the universal elements. How in unrelated individuals one may find a universal will, is a matter which did not vex the Genevan philosopher. He stated the case as he saw it, and left the matter of reconciliation for others. Indeed, one is disposed to look on the contradictions in the philosophy of Rousseau, by which he marked the transition from eighteenth to nineteenth century thought, as an evidence of his strength of mind.

\section{$M r$. Herbert Spencer and the Biological Theory.}

In a preceding chapter a brief statement was made of Mr. Spencer's social theory, so that it will serve the purpose here to consider how far his plan provides for social unity and for individual freedom.

As he teaches that society has an organic character, it would seem that sufficient provision is made for the side of order, but it is to be remembered that $\mathrm{Mr}$. 
Spencer's organism is physical, therefore is controlled by physical laws. Since he has no place for a social mind, it follows that there is no natural function for Government to perform. Mr. Spencer's State has no will, no power of self-direction. What the State would become, what direction it would take, it is not in the wisdom of man to predict or direct, and God is at the least an absentee in his system. A State such as Mr. Spencer conceives, evolved by the integration of matter, and the dissipation of motion, sustained and guided by persistent force, without the direction of will either human or divine, does not appear to furnish the conditions of social order. It reminds us rather of the ship without engine or rudder, at the mercy of the physical forces of wind and wave.

Scarcely better does his theory fulfill the conditions necessary to individual freedom. The individual, as well as the society, is under the dominion of physical law. Mr. Spencer argues stoutly for the non-interference of the Government with the individual, but on the ground that he is subject to physical laws to which he must conform. The laws of heredity and environment, inexorable since there is no will to mediate their effects, hold the individual in their viselike grip.

Persistent force can have no regard for the being which is in its path; it can only crush. It is neither merciful nor merciless, neither just nor unjust; it is relentless. Leave will out of the social problem and there is nothing to which the weak may appeal against the strong. Might is right when persistent force rules in the affairs 
of men. A world without a God of love is a world without hope.

\section{The Psychological View.}

The preceding theories have been, to a considerable extent, identified with the name of particular individuals ; the psychological theory is too recent and too much the accepted premise of modern philosophy to be identified with any particular name. It is the view which is in opposition to the materialism of Darwin and Spencer and divides the field of present-day thought with them.

In comparison with the theories of the State which have been set forth in this chapter, the thought of the State as the social spirit, the thought which the psychological view is based upon, seems to afford, in fuller measure than the others, the conditions of individual freedom and of social unity. The mechanical divisions into social classes, as well as the dissolution of families, devices which seemed to Plato necessary for the securing of social order, did not leave sufficient place for the development of individuality. Aristotle partly followed, partly corrected, the one-sided teachings of Plato; indeed, it may fairly be said that the psychological view coincides more nearly with Aristotle than with any other of the early social theorists except Moses.

The philosophers of the social contract, in trying to correct the faults of the Grecian and Roman thinkers, took the usual course of those who oppose one extreme by landing in the other, destroying society in order to save the individual. Yet while we are compelled to pass 
this judgment upon such men as Rousseau, justice demands the remark that just such extreme method was necessary to break down the institutions which were oppressing the individual. When "the grand monarch" was pleased to say, "I am the State" it had very much the appearance of fact, since the administration of public and private affairs as well passed through his hands. He realized in France something of the condition proposed by Pharaoh when he said that no man in all the land of Egypt should lift up his hand or foot but by the will of Joseph. With such absolute pretensions there seemed to be no possible compromise, so that curing the "king's evil" involved the killing of the king. The precedent of Rousseau and his like, with the consequent of the French Revolution, seemed the only release for the French peasant from intolerable conditions.

It is, perhaps, too early to get at the social value of the materialistic views of society proposed by Darwin and the other biological evolutionists. It seems to be the case that each social theory, when far enough away that we can get its social bearings, has been the child of a present need, as well as the parent of some social improvement, this being the case even when it is fatally defective as a complete statement of social facts. Mr. Spencer, by his describing the social in the terms of the animal organism, has doubtless aided in clearing our minds for a true understanding of the nature of socicty; bit that should not blind us to the fact that his materialistic view of society fails to provide for the closest social unity as well as for individual freedom. 
When Mr. Spencer makes the point that since nervous control is not centralized in society as in the animal organism, and that therefore there is no social mind nor any place for Government, thus stating the premises of philosophical anarchism, he is not providing the conditions for social unity.

When the psychological conception of the State defines it as the social spirit, it makes provision for the closest unity. Every man who is in fact a citizen has this social spirit as a factor in his life; it is a part of him and because of this fact the whole citizenship is united in a spiritual union. It is the man million.

One of the clearest statements of the relation of the individual to the State, is found in the first chapter of Genesis. There, after the material creation had taken place, it is recorded that God said: "Let us make man in our image." The carrying out of that divine purpose meant that man should be like God, that is, that there should be diversity in unity. We learn in a book which is not antiquated in its statement of facts that "there are three persons in the Godhead, the Father, the Son, and the Holy Ghost." There are three, yet there is one. Society made in the likeness of God has the same character; there is one and there are many.

Jesus states the ideal condition, only imperfectly realized as yet, in his prayer that, "they all may be one." But though not realized in its fulness, it is the social unity which in spite of all divergences makes citizenship a kinship of life. As the State realizes its true ideal, the perfect unity which is in the plan of God and the 
destiny of men will be manifested. Thus does this view of the State make the fullest provision for social unity.

It must be admitted that there are social classes and individuals " discordant, belligerent," in which the common mind, the social spirit, exists only in promise; but it exists. The defect is not in the plan, but in its realization. Aristotle makes the point that the social conflicts are, after all, proofs of an underlying social unity, the very conflict being an evidence that the parties belong to the same sphere, are related to each other. The struggle between the capitalist and the laborer, which is continually developing new phases, gives evidence at every turn, of the dependence of each class upon the other. Capital is useless without labor; labor is inefficient without capital.

The idea of the Trinity also allows for the complete individual freedom of each member, and this because the same mind is in all. When Jesus did the will of the Father, He was also following His own will. " $\mathrm{My}$ meat is to do the will of him thāt sent me," Jesus said, and his saying gives us the meaning of His life. $\mathrm{He}$ was perfectily free and those who share in His life have "the glorious liberty of the sons of God."

Now it may be objected that the members of society are very far from the perfection which belongs to those who realize the divine plan, but let it be remembered that philosophy deals with the nature of things, with things as they are fully developed. Social philosophy and that is what concerns us here - has to do with ideal society. Plato, Aristotle, Rousseau, Hegel,-all dealt 
with social ideals. The nature of anything is its ideal condition, not some stage in its earlier development.

Paul exhorted those to whom he wrote: "Let the same mind be in you which was also in Christ Jesus," and the nature of society is realized only when it has the mind of Christ. The claim here made is, that with all due regard for the previous social theories and the work which they did in social reconstruction, the psychological view of the State as the social spirit is the only social theory which conforms to the Christian ideal. While the theory here stated will doubtless be enlarged and revised as fuller social knowledge is gained, it does not appear that any except a spiritual conception of the State can provide the conditions of unity and individual freedom.

\section{A Comparison with Plato's Theory.}

Freedom means the fullest activity. The given conditions in the problem of each individual are the life which the individual has already gained, the social life about him, and the divine life. There is nothing except these. When the individual life seeks its fullest expression it must be found by going out into the life of society and the life of God. It is in this way that the individual life develops, gains a fuller activity, a more perfect freedom. Anything which prevents one from putting himself into the life of his fellows and the life of God retards freedom. With this statement, which is certainly true if man is essentially spiritual, we may test the work of Plato. 
The ascetic who, in order to get unity with God, shut himself off from men, left out one of the elements necessary to work out either freedom or unity. He gave up the world's problem and confessed defeat by retiring from the field.. Plato made a similar mistake. He saw that men were selfish and that selfishness stood in the way of social unity. So far he was right. How shall men be freed from selfishness so that they may unite with each other? Plato said we must take away his property and his family, and then he can not have a selfish object. But can men be made unselfish by any such mechanical means? What is needed rather is to make men see that wealth and family are only means to gain a greater activity, a better social unity. In the divine plan all these things were given as a means to the development of spirit. We must not throw them away. Man must learn to be unselfish in the use of money, in the treatment of others in the family. Before both of these he should put his country. It is not allowable for us to solve our social problems by throwing away such of the factors as do not work out the answer we want. The correct solution needs each one.

\section{A Comparison with Mr. Spencer's Theory.}

It may be suggested that the chief error of Mr. Spencer was in trying to work out a spiritual problem with material tools. He did not take in all the conditions of individual freedom, since he left out the life of God entirely from his theory, and reduced the human spirit to subjection to physical laws. It is true that he did 
not deny that there was a God, but his answer was made up without any regard to Him, thus throwing away the only key to the social situation. Without God the individual, subject to inexorable force, is but as a mote in the sunshine, the chip in Niagara. Fate is the blind arbiter of the destiny of man and of society.

The Kingdom of God, Herbert Stead; Politics, Aristotle; Aristotle's Politics, Lang; The Republic, Plato; Political Theories, Dunning; The Social Contract, Rousseau; Rousseau, John Morley; Essays on Government, Lowell, pp. 136-189; Social Statics, Herbert Spencer; The Man versus the State, Herbert Spencer; A Plea for Liberty, Herbert Spencer; Social and Ethical Interpretations, Baldwin. 


\section{THE FACTORS OF SOCIAL UNITY}

FreEdom is the end of the individual; unity is the end of the State. These ends are not antagonistic, nor can one be secured without the other. It is only when the social elements are adjusted and working in harmony with each other, that unity is secured; only under such conditions is individual freedom possible. Admitting this to be a statement of fact, it is an easy step to the conclusion that any psychic factor which ministers to social unity must, finally, work for freedom. It may work for one end directly, the other indirectly, but no less surely. Among the factors of social unity we may notice race, language, religion, and social commerce.

Race.

Race serves the double purpose of binding together a certain community, while, at the same time, separating it from all other communities. While descent from Abraham, their common ancestor, helped to fuse the Israelites into one people, at the same time it shut out all who were not of the same lineage. Yet it was necessary. then, as since, to sacrifice temporarily the wider unity for the sake of training a few people to live together. Social unity is realized by a process of growth, which may not be unduly hastened without social damage. With all the training which the Israelites had as a separated 
people, their tribal jealousies had prevented such devotion to a common worship and interest as could survive in the face of national disaster, until the exile sloughed off all those elements of the population that lacked the common spirit.

This is a suggestion of the fact that race does not mean simply descent from a common ancestor. Every tribe and individual of the Jewish race could and did boast of descent from Abraham, but that was not enough to integrate their lives. The bond which held them together was not simply one of blood. As a matter of fact, the tie was rather psychical than physical. It consisted in a common history and tradition. Few peoples have had so rich a fund of memories as Israel. Crowded within narrow territorial limits, were some of the most remarkable events which history records. Every valley had been a battle ground made sacred to the children by the father's blood; every hilltop had its heroic sacrifice to glorify it. With this common heritage of glorious memories, this people had ideas which bound it together in such fashion as the blood bond could not have done.

As these memories were usually of heroic struggle against surrounding communities, love for the home land was united with hatred for the foreigner; indeed, the very name applied to foreigners was the term for enemies. Each people must watch the line of its frontier only less in time of peace than in the frequent wars. Whatever duties might be taught as due to those within the community, nothing was due to the man outside the pale. 
It is this fact which makes so unparalleled the saying of Paul, himself of the straitest sect of the chosen people of God,- "I am debtor both to Greeks and to Barbarians." None of the sayings of the Apostle to the Gentiles more clearly brought out the transformation which Christ had worked in him, than this acknowledgment of a duty to the foreigner. This hatred of all beyond their own bounds served its social purpose in preventing their mingling with other races. Their antipathies as well as their sympathies ministered to the social end.

This leads to the suggestion that influences which are socially helpful at certain periods in history, may be baneful at others. In early times it seemed essential that the group should develop in isolation, that it might be fitted for a wider life. Individuals need to be trained in the family if they are to do their work as citizens, so does each people require its separate education to enable it to perform its duties to humanity. The development is one of mind, rather than of a physical nature, therefore is rather hindered than helped by the application of physical force. It is likely to remain a mooted question whether civilization was retarded or advanced through the crushing of national individuality by the force of Roman arms. In a study of the psychology of peoples, it is difficult to see how mind can be developed by spear or bullet.

Poland was not a united people at any time, since the Government was administered by a selfish nobility which resisted all reforms that might ease the burdens laid upon the serfs, yet is the Polish spirit of sufficient 
virility to give Prussia a serious problem in its attempt to Germanize the Polish communities which were acquired in the partition of Poland. Prussia went to considerable expense to borrow this trouble and the payments are not all made. Bismarck will not be charged by those who are familiar with his life with being too scrupulous, but he was statesman enough to oppose, as he is said to have done, the taking of Alsace by Germany in 1871. The indemnity paid to Germany was not grudged by France, but the severing of Alsace was taking part of the life.

Each people, as each individual, has its own peculiar genius. Not in all cases is this so evident as is the art of Greece, the legal acumen of Rome, and the freedom of the German, but in less striking degree it is present. Who can tell what of national genius was crushed out of shape or existence by the empires of the past! The saying of the Mohammedan conqueror when he ordered the destruction of the Alexandrian library, that if the.knowledge stored there was in the Koran they did not need it, and that if it was not in the Koran they did not want it, is the language of the conqueror in all ages. It is his end to compel other institutions and other ideas to conform to his standards, with destruction as the only alternative. It is a social injury when an individual loses his individuality, much greater is the loss when the same must be said of a people. The attempt to fit a man to his clothes is attended with much pain and no little deformity, nor can we, without the application of the rack and the boot, fit one people 
into the institutions of another. The proper course is to change their minds, and the institutions and ideas will change themselves.

Rome contributed much to the formal unity of the world, perhaps little to its psychic unity. For the latter purpose the methods of Paul were superior to the methods of Caesar. Paul's conquests remain, while those of the Caesar vanished with the retreating legions. One social service the ancient empire sought to render; while it sent out its legions of trained robbers, it insisted on a monopoly of this particular business and drove all others out of the trade. Private robbers were suppressed on the land, and pirates, on their own individual account, were driven from the sea. The great contribution which Rome made to the unity of the world was the system of : laws, which has a large place in the jurisprudence of all constitutional Governments.

Through physical and psychical heredity, and specially by the latter, races develop along consistent lines. They breathe the same atmosphere of thought, they hold to the same traditions and relationships, cherish the same ideals. This is the race life. It is not only that it lives in the individual, but he lives in it. One can not vivisect the individual and discover his life, nor can the race be dissected and the social spirit located, but it is evident that there is life in both cases from the effects which are produced.

In the course of history, races are frequently divided, and, through peculiarity of position, develop in somewhat different ways. England and America belong to the 
Anglo-Saxon race, yet the civilization of the two countries has not followed the same line of development. It may not have been the typical Englishman who settled in the colonies, the environment of the pioneer was quite different from that which he left behind; whatever the cause or causes it is evident that the sea is not the only division between England and America. The physical basis may be much the same in the two peoples, but the psychic differences are marked. A good degree of success along industrial lines has made the Anglo-Saxon intolerant of opposition and left him a somewhat unpleasant associate for other peoples, but the citizen of either country has usually demanded a large amount of freedom for himself, even though inclined to limit it in others. His leading characteristic is a determination to rule. When the proposed reunion of the Anglo-Saxon race is achieved, by which the gap opened in 1776 is closed, the important question will be which is to be head of the Anglo-Saxon household. In neither case, with present indications, will there be any desire for the lowermost room.

\section{Language.}

A word is the expression of an idea; language is the expression of social thought. An individual may coin a word, but he cannot give it currency. It is like money, in that its simplest test is whether others are willing to use it. A word can not go into the language unless it can be put in circulation; it can get into circulation only on condition that the same idea is in other minds and 
demands expression. When a writer has an idea which he thinks no word in the language adequately expresses, he makes a word and puts it on the market like a commodity. It is when they do not meet any social demand that words die.

It is for these reasons that language is a social product. Comte said that the man who denied the existence of society belied his statement by the words he used, since these words were the product of the society whose existence he denied.

Language is one of the evidences of a social mind. The language of a people is an enduring monument of its character. In the language are recorded the thoughts of the social heart. Few poets have spoken the heart of a people more than did Robert Burns, and it is indicative of the morals of his age that it is necessary to prune his language to satisfy the present standard. Shakespeare, whose lofty thought is the wonder of later times, is read today in an expurgated edition. It may be said that later times have learned to hide their vulgarity under more polished phrases, but at least it can not appear upon the printed page. Very clearly is the change of social mind from the Elizabethan to the Puritan age marked in the contrasted language of Shakespeare and Milton. The seriousness which could find expression only through the phraseology of the Old Testament prophets is in strong contrast with the license of the writing in the time of Queen Bess. One may read the morals of Rome no less in the language of her poets than in the pictures of vice upon the walls of the 
buildings in exhumed Pompeii. Even the translation of passages of Latin which are used in the classroom, would not be tolerated in the columns of our daily papers. What the language of the vulgar must have been is left to our imagination, but it at least yields to us the reason why Rome collapsed at the coming of the German. The corruptions of the people are embodied in their speech.

Each people has a language distinctively its own. When the student takes up a foreign tongue, if he would understand its shades of meaning, he must put himself into the life of the people so that he can see things with their eyes and think with a mind like to theirs. $\mathrm{He}$ can not put their thoughts into his native tongue, except in crude fashion. If he is dealing with the language of a living people, the thought of the age will give the foreign tongue some kindred with his own, since there will be many points of contact; but if it is the language of a people which has passed away, his task is more difficult. It is hard to place one's self in ancient Greece or Rome. This is plain to any one when he reflects how changed are the standards and customs, the problems and proposals for their solution. Then as now the contest was on between the rich and the poor, but the conditions of the contest and the demands are entirely different.

These commonplace illustrations enable us to pass to the proposition that in the present stage of social development each people should cultivate its own language within its boundaries. The babel of tongues which one may hear in the streets of New York is the proof of 
divergent thinking and interests. These must somehow be unified. Scarcely a people of the earth but has its little segregated community living the life, and voicing the ideas of a foreign land in the commercial heart of this country. The object in coming here was to gain the wealth which is currently reported abroad to be here for the taking, while the immigrants have little sympathy with the American spirit and institutions. Food to eat, shelter to live in, clothes to put on, fill the measure of their wants. They need enough of our language to buy and sell in the market, even that being unnecessary if the community is large enough to live to itself. The lower class of immigrants are usually worked in gangs, where only the leader, who fleeces his countrymen for his own advantage, can speak English. These segregated groups carry on their business in their native tongue, in which, also, their newspapers are printed, and to all intents they are foreign communities. How shall these be made to imbibe our social spirit and become assimilated to the life in which they exist as foreign elements?

To get a use of English is not the most essential thing, but it is one of the essentials if these foreigners are to gain the ideas embodied in its words and to share in the social spirit which finds expression through it. It is poor economy which grudges, or withholds, the money for schools to win these peoples in our midst to our ideas, thus neglecting the alien population, at home, and which squanders millions on an ironclad with which to coerce foreign populations abroad. At the present 
time there are 60,000 children in New York City without school accommodation. As one looks on such a situation he feels a measure of sympathy with the view of Professor Lester Ward that we are still guided by animal instincts, not having emerged into the sphere where reason reigns. It is not essential that some other people in another land should speak our mother tongue, since it is possible, and probable, that their social characteristics would find better means of expression through the one which has grown with their life, but we should have one language taught and spoken from New York to San Francisco. The Boer was only providing for the existence of his nationality when he insisted that Dutch should be the language of the schools. Through all the conquests by Dane and Norman, the mother tongue was retained by the English people. Thus they preserved their nationality.

Germany has a language problem on its Eastern and Western frontiers consequent on its greed for territory. In the Polish districts on the East it is reported by the press that the native tongue is prohibited in the prayers which the children are taught, while Alsace on the West had the French language taken from her schools by imperial decree. The question of language is fomenting the dissensions that exist between the struggling nationalities in Austria-Hungary. Even Ireland, where the Celtic tongue had been almost forgotten, is having a renaissance of her original language. In each case it is the race spirit which is demanding expression through its native medium. 
The fact which statesmen must see as it is written in history and current events, is that the spirit of eacheple should be allowed expression in the way peculiar to itself.

One of the standing charges against economic socialism is that it would take the diversity out of life and reduce it to a dead monotony. Whether this charge is in any way supported by the evidence, is left to each to decide for himself, but it is notorious that the classes most opposed to socialism are busily engaged, in many cases, in trying to enforce their institutions upon reluctant peoples.

The free spirit is what we wish to develop among human kind. Each people requires its own mode of expression and this should be common to all within the country, since the common spirit is what makes them one people. Switzerland is an anomaly among the nations, since, though divided into opposing camps in religion and having no language of its own, it has preserved its freedom and developed its own peculiar institutions. With the religious demarcation between the Catholic and Protestant Cantons, with the larger part of the population speaking the German language and singing the national songs of Germany, with the Italian tongue on the southern slopes of the Alps, and the French near the Jura Mountains on the West, yet Switzerland has a united people. The national traditions and common interests maintain a common life in spite of the varied forms through which it is expressed. However it may be possible for certain communities to 
retain their unity in spite of diversity of language, it is yet certain that a common language ministers to a community of thought. The proposal, in certain places, that German should take the place of English in our common schools could not be accepted with safety to the State. The children of the foreigner should learn our language, be taught our national songs and our history, be connected by every possible channel with the social life. We can not afford to have a Little Italy and a Little Russia in the great centers of population, which are also the centers of influence.

\section{Religion.}

"In ancient times," writes M. DeCoulanges, "men knew no other relation than that which religion established." All the acts of the individual and of the city, were regulated by the gods. The father, who was also the priest of the family, must, before he began the duties of the day, propitiate the sacred fire upon the hearthstone. He could properly sow his field only when he had discovered by the signs that the gods were favorable. Before corn reached the ear, ten divinities had been consulted in Rome. The gods of the mildew, the rust, and the sunshine, must all be worshiped with the proper formulas. Indeed, most carefully must these formulas be followed, since the omission of so much as a gesture, might call down upon the hapless husbandman the wrath of the offended diety. Men did not love the gods, nor was it suggested that the gods had any love tor men, but these services were rendered with 
anxious care, to avert the vengeance of the rulers of the torces in earth and air.

At the boundary of the fields were the stones set which were sacred to the gods Termini, and the removal of these landmarks would be an impious act. For centuries did these superstitions supply the place of police surveillance, and when Horace speaks about the rich men uprooting these landmarks that they might appropriate the plot of the poor, it shows that religion had ceased to afford protection to the weak against the strong. Such an action would have been impossible until Romans had lost faith in the gods.

The farmer rendered scrupulous service to the dead as well as to the living, since his steading belonged to his family, past, and present, rather than to himself. His fathers, to the earliest generations, had their graves beside his home and as regularly as food was prepared for the living, must it be presented in offerings to the dead, that they might not wander as lost souls in the nether world. Such would be the condition of the whole line of ancestors, if the family should become extinct, so marriage was carefully guarded and children from other families were adopted, when necessary, to keep the line intact. The most illustrious of the Emperors of Rome, those from Nerva to Marcus Aurelius, were children by adoption of the preceding ruler. The purity of the family relation was demanded for the welfare of the dead:

The city, which was the State as the Roman knew it, was founded on religion. The situation was not, 
first of all, determined by its suitability for commerce, nor for defence, though these interests were usually conserved in the result. It must be placed where the chief man, acting as priest for the others, found the gods favorable. Along the proposed site of the city walls a furrow was drawn to mark the line, the plow being lifted from the earth at the places where the gates must stand. Had the furrow been drawn entirely around the plot of ground, no one might have entered it, since it was an act of impiety to cross the furrow. It may have been to show the anger of the gods with such a sacrilegious act, that the mythical account of the founding of Rome records the slaying of Remus by Romulus for leaping over the wall. All within the city wall was consecrated ground, and here were placed the temples of the gods with the Government of the city, for in those times the gods supervised both the ecclesiastical and the political functions. Here was the civitas, and the citizen was the man who was priviliged to share in the worship at this shrine. The urbs outside was for the dwellings of the people, for in the sacred place the priests must dwell alone, and keep jealous watch upon the sacred fire, the extinguishing of which was an evil omen for the city. In Rome the Vestal virgin through whose carelessness the fire went out must suffer death. When it was extinguished it must be rekindled from a pure flame.

Into the worship of the gods of the city no stranger might intrude lest he defile it, and none might be citizens who did not share in the common worship. However 
jealousily the ancient Hebrews guarded their faith from the intrusion of foreigners, they drew the lines less closely than did the contemporary Greeks. So carefully were the religious rites and citizenship-for these went together - guarded in Athens, that in her early days a stranger became a citizen only after much formality. He must be accepted twice by the vote of the assembly, the second election requiring six thousand votes in his favor; he then must be passed upon by the senate, and even after acceptance with this body the negative vote of a single citizen would cause his rejection. Yet this was the rule in what men are pleased to label the Athenian democracy. As a citizen at Rome the individual was a member of four religious orders - the family, the gens, the curia, and the city. Each of these must be entered by specified religious formulas excepting those who became members of the family by birth. Each institution had its gods to whom worship was due.

The head of the Roman administration, be he king or consul, was the chief priest of the city, and in the sacred limits he offered sacrifices for the welfare of the city, and, through the auspices, received the will of the gods for the conduct of affairs. Was a battle to be fought, was a peace to be concluded, he must consult the gods. At Platea, so much were the Greeks dependent on the will of the gods, that they suffered their first ranks to be slain by the enemy, waiting until the auspices would be favorable for beginning the attack. The convoking of the legislative bodies, their dissolution, the business to be transacted, must all wait until the augurs 
reported that the signs were favorable. This put an immense power in the hand of the augurs, since all public business waited on their reports of peals of thunder, of flights of birds, and other signs to which they looked in order to know the will of the gods.

These provisions indicate the place which religion had in the early society. It presided no less in the making of the laws than in the offering of the sacrifices. The king as well as the priest must be acceptable to the gods, since upon their favor depended the safety of the city. It was thus that religion bound the city together, but at the same time it rigidly excluded the stranger. Before the Romans could conscientiously steal the Sabine women for their wives, it was necessary to discover that they had some gods in common. No matter what phase of Roman life is examined, it would be found that there was provision for religious control. Religion was the social bond within the community; it was the barrier against all intercourse with other communities.

This was the idea of the ancient faiths. It was as natural that each locality and people should have its own god as that it should have its own king. Each band of worshipers had its secret cult, which must not be revealed to the uninitiated. Some of the more recent secret orders have many points of resemblance to the early religious association. When the wife was brought into the Roman home, she had to be initiated into the secrets of the religion which she must never reveal. Thus it is seen that the ancient religion not only sep- 
arated each community into castes and classes, but it shut out each community from every other. So long as Olympus had its quarrels among the gods, it followed that there could be no close unity of the Greek cities which served the Olympian gods; so long as divinity was thought of as divided, humanity could gain no universal bond which could bind its members into a common life. Monotheism made this unity possible.

Christianity served the social unity because it was universal and not limited to any locality or community. Thus, instead of separating men into warring groups, it bound them together in a common life. In any part of the earth the man who can say "Our Father" is kindred to every other whose heart makes the same confession. While the ancient peoples called upon their several gods for their assistance as they went into battle, we see the spectacle today of different people each calling on this one Father as they go out to burn and slay. No nation, or tongue, or kindred, or people, can be outside the scope of the Christian religion. In its very nature it is universal and inclusive of humanity. A fatherhood in heaven necessitates a brotherhood on earth.

The ancient religions not only excluded from their favor all outside the particular race, but they formed classes within the community. This is one of the facts which Hinduism must explain when it is put forward as a rival to Christianity. That classes are segregated among ourselves must be admitted, though too far from the exclusiveness of caste separation to bear comparison, but this social separation exists in contradiction to the 
teachings of Christianity. Hinduism, on the other hand, is bound up with this caste system. The Bible puts forward Jesus as the meeting place of all classes, learned or ignorant, rich or poor. He has not only "made of one blood all men," but he furnishes in himself a common point of contact. All class separations are in violation of His teaching. He met with the rich and the poot, not because of their riches or their poverty, but because of their manhood. That which men count as distinctive badges of superiority, has no value in the economy of Jesus. Burns voiced the social teachings of Jesus when he said: "The rank is but the guinea's stamp. The man's the gold for a' that."

Christianity is superior to materialism as a social bond in the same way that the former excels the early faiths. Materialism sets forward as the end of man's efforts, that which divides society instead of unifying it. Professor Clark in his treatise, "The Philosophy of Wealth," makes the point, that so long as the attention of both employer and employed is fastened on distribution, there can be no more than temporary truces between these contending parties, since the gain of one is regarded as the loss of the other party. Professor Clark argues for some agreement as to a ratio of division of product, so that both employer and workman could give their whole attention to the production of goods, a point in which they might agree. Now materialism fails by directing men's minds to this question of distribution. Since it makes material goods the prize of life, and since there is never enough to satisfy man's selfish desire for 
display, if not for comforts, chere must be dispute over the division of goods. For this, materialism can afford no cure. If man's end is not material, but spiritual, he is dealing in goods where the gain of one may be also the gain of another, never his privation.

\section{Social Commerce.}

This term is used to include all exchange in ideas which is going on between minds. That the social mind may perform its function in social control, there needs to be some free forum for the expression of divergent individual opinions. In a small way this is realized in the classroom, where each individual gives free expression to his best thought, and the teacher's work is found in making a consensus of the views, harmonizing them, so far as may be, into the complete truth. Anyone who has experienced such training has gained through the calm, frank interchange of views more respect for the views of his neighbor and a larger conception of the truth.

The political campaign affords some facilities as a free forum. but the writing and speaking is usually for the purpose of defeating an opponent, rather than to get at the truth in the issue. One who has listened to a discussion on the street, or on the platform, would be impressed with the intolerance of the parties of any modification of their views, rather than a seeking for a broader range of mental vision. Excited men can not weigh opinions and get at their social value. One of our great difficulties is our ignorance of the position held 
by those in other occupations, or in other schools of thought, and whatever will enable us to gain their point of view will be of great social advantage in bringing social classes into harmony.

Nor does the press, as at present conducted, satisfy the demands of a public forum. Such it should be, but in its real or supposed need to cater to the subscriber, and specially to the advertiser, it gains only an individual point of view. This fact is not resented by most readers, since one usually likes to have his own views presented rather than those representing some other phase of the truth, and is ready with the threat "Stop my paper" whenever some other chord is struck. There are a few newspapers which may fairly be classed as independent, and thus capable of looking at current events without partisan bias, but they are lamentably few. The great bulk of the political press is working social damage through the ignorant, or intentional, perversion of facts.

There are many ways in which this interchange of ideas is being carried on, though perhaps in no place is it so fully realized as in the classroom, but this agency represents the different social classes only partially, some are not repreented at all. What is needed is a social forum to include those representing every phase of the social problem.

History of Civilization, Buckle; Physics and Politics, Bagehot; The Ancient City, DeCoulanges; The Philosophy of History, Hegel; The Incarnation and Common Life, Westcott. 


\section{THE SOCIAL MIND}

History has been written from many points of view, each writer congratulating himself on having compassed the whole situation. Going so far back as the Middle Ages, the chroniclers dealt only with ecclesiastical affairs, with some attention to the rise and fall of kings; with the rise of the European nationalities, history came to be written from the point of view of the titled few who were in political control; in recent times history has been said by Karl Marx, and the materialisitc school which he represents, to owe its changes solely to economic causes. Now, whether history can be written from the standpoint of the social life, instead of that of some specially favored class, may be doubted, since it is open to question whether any one mind can grasp the whole life in a single view. At least we can see that this should be the aim of the historian.

The economic, the ecclesiastical, the political, are only different phases of life. The writer of biography looks at the life and surroundings of his subject, but it is not necessary for him to fall into the error of Carlyle and imagine that biography is history, even where great men are concerned. History can not be the biography of certain men. The social life is larger than the individual life, and the whole includes the part, not the reverse. Luther did not make the Protestant Reformation; Samuel 
Adams did not produce the American Revolution. Both men put the unspoken thought of many into spoken words, and made themselves the rallying point for an idea. The idea was not of their making. The service which the great leader of men renders is to put popular thought into a concise form which all can understand.

A social revolution is the fruition of a social idea. Far back in the years the idea was the possession of some forgotten individual, and men have struggled and died that it might win the popular approval and enlarge the social life. Until the fifteenth century Europe had faced the East and the past; then it faced about to the West and the future. Till then pope, king and Church had been measured by ancient standards; now they must stand at the bar of a new idea. The nations had been in leading strings to Rome; now her Empire, now her Church. The time had come for an idea to pass judgment upon the judge. The Council of Trent sought to restrain the idea by all the methods which had succeeded in the past crises of the Church of Rome; the feudal barons tried to save the old institutions; but the result, however long delayed, was that institutions had to be adjusted to the idea. The invention of printing, the discovery of America, the coining of money, the beginnings of commerce,- all gave expression to the new idea. It was a change of the social mind.

History is shaped primarily by ideas, by psychic influences; it is a development of the social mind. It might seem, at first sight, that this made social development a simple process, leaving no place for war, for 
heroic action and martyr blood, but the getting of an idea is a painful process, as anyone will witness who has experienced it. When it comes into the individual mind, this new idea compels a rearrangement of the whole system of knowledge to fit it. Often some of the lares and penates of the household have to be displaced, or even cast aside in this rearrangement. Perhaps the less mental furniture there is in stock, the greater will be the objection to moving it about, or discarding it, in giving place to the new conception. The fabulous account of the Western chickens that fell on their backs and held their feet up to be tied, when a covered wagon came along, suggests that frequent changes make it easier to adjust oneself to new situations. However, if the individual repels the new idea until it has become a common possession, and has revolutionized social institutions so that they conform to it, he comes by it with a minimum of effort.

In the social mind the struggle incident to getting the new idea is more evident. What it has meant in this country to gain the idea that the status of manhood is not determined by the color of the skin, what it means still, needs no explanation to give it vividness. The coming in of such an idea means not simply an adaptation of former ideas, but the adjustment of institutions to which former ideas have given rise. The thousand questions which arise in the negro problem mean, each and all, the conflict of an idea with established institutions. What this idea has cost in terms of pain is beyond computation. Not all ideas require such radical changes 
as the one just mentioned, but a re-adjustment must be had in each case.

It is because of the difficulty of getting a new idea, that the man who has spent a large part of his mature years in advocating a cause in which his life has centered, is seldom able to put the same vigor into the presentation of another, when this idea has been accepted. Wendell Phillips, one of the greatest exponents of the abolition movement, did not show equal force in any other. Many men now living have not adjusted themselves to any thought movement since the Civil War. No later idea has gained possession of their lives.

The same fact is apparent in social institutions. When an institution has grown up about an idea, the institution is seliom able to adapt itself to new issues. The Republican Party was formed for the restriction of slavery to the existing slave territory and later forced the amendments legalizing the fact which Lincoln created by the Emancipation Proclamation; but since that issue was out of the way more than a generation ago, no definite idea has taken its place. Since that time there has been no defined issue between the leading parties but the possession of the offices. The Democratic and Republican Parties each stand for more or less of what the other wants. Only the minor parties have presented clear cut ideas and definite issues.

Until recent times the leading political parties were divided in regard to the treatment due the negro race, but that difference has disappeared. The union of sentiment between North and South in connection with the 
Spanish War came about because it was recognized that the leading party of the North no longer stood for the equality of subject with dominant races. This is, however, rather a reversion to an old idea than the acceptance of a new one, though it seems to demand some change in our political institutions which have had some considerable taint of democracy. History deals with the inception and development of social ideas.

These social ideas must arise in a social mind and it may fairly be assumed that it has the characteristics of the mind of the individual. There is evidently a certain amount of social intelligence, which fact suggests a social intellect. Social feelings present themselves so forcibly to the attention, as to leave little doubt of an emotional element in society. In support of the assumption of a social will, one need not do more than cite the popular phrase "the will of the people" and notice its working in social control. If, then, we find evidence of a social 'mind, with its phases of intellect, feeling, and will, we may fairly conclude that there is a social psychology corresponding, in great part, to the psychology of the individual mind. The study of the social mind will, therefore fall under the heads of knowledge, feeling, and will.

\section{Social Knowledge.}

It has been seriously questioned whether the child of today comes into life with any greater mental power in his possession, than belonged to the child in Athens or in Rome. The modern can produce a better history, or philosophy, or machine, than was possible to the indi- 
vidual of earlier times. But is this greater efficiency due to superior individual capacity, or is it due to the environment in which his work is done?

It may be that his advantage over the citizen of the ancient city, is due less to his individual superiority than to the social inheritance which falls to him. While the intervening generations have passed away, they have left behind them the results of their labors and genius in social knowledge and social institutions. These are the earnings of the past, and the tools which the modern has at hand with which to begin his work. All this inheritance from the past is so much fixed capital by which the efficiency of the individual is vastly increased.

This is aside from the matter of material things in which monopoly is having its perfect work. There is no trust formed in ideas. Perhaps this statement should be limited to the extent of saying that monopoly of land or factories may raise a barrier to prevent the individual from entering into possession of our social inheritance of knowledge. If we wish to travel, or to send a message, we have the steam car, the telegraph, the telephone; if we wish to give an idea to the world we send it to the printer. If we wish to develop individual minds, we find the ideas wrought out in the storm and stress of centuries in the culture which we inhale as the breath of mental life.

Social Ideas.

Social ideas originate in the mind of individuals, and are socialized through imitation and repetition. In child 
life imitation has nearly the whole field. The child is given advice in regard to conduct which it, in turn, hands on to animate or inanimate playthings, the doll or the cat, finally to the other children with whom it plays. When the child plays house, it copies both the words and the tone of its father and mother, and in its dealing with playmates seeks to rule them after the fashion of its own experience. He will even bring in the gestures which the parents habitually use to enforce their orders.

The results of imitation are as clearly seen in the life of the neighborhood. Each neighborhood has its own language, differing in some respects from any other. Joseph Parker said that he could tell in what English county a man was bred if he could hear him speak. This comes about through imitation which constitutes the conservative force in the social life. While our acts differ in some respects from our neighbors, for the most part we imitate them.

The Chinese are noted for their imitativeness, having been trained to it from birth. It is their care and their pride to do as their ancestors have done. Under such circumstances ideas must be common to all and a stable order of things will be secured.

The difficulty arises when one tries to bring in a new idea. Men speak lightly of giving Western ideas to the people of the Orient, as if the offer of the new would make them wish to discard the old. The ideas of the Chinese suit them quite as well as American ideas suit us and the Chinese have as much unreasoning pride in their institutions as have the Anglo-Saxons, though the 
Oriental does not show such determination to force his institutions upon unwilling peoples. It is one of the psychological defects of the child races, which makes them immune to Western civilization, that they are not able to subordinate all other interests to those of trade. A Western community accepts with avidity the idea of a railroad in their neighborhood, but to the Chinese the operations of the road would dislocate social institutions which have been thousands of years in the making. It means little to these people that it will do better work, or more work, than the old methods. It means a mental as well as an industrial revolution, the results of which neither they nor we can foretell.

But while the habit of imitation dominates the Occident less than the Orient, it is yet an important factor in life. It is safe to say that not more than one-tenth of the voters of the country are at all affected by the party platforms, or the arguments of the campaign. Ninetenths of the voters accept the candidates and the platforms which the machine engineers prepare, and the knowledge of this fact makes politicians careless of criticism. At some distant period in Chinese history the women bound their feet and it has been imitated until it has become a mark of social distinction; perhaps for the same reason the waist is bound in the West, a custom which is not less prejudicial to good health, for though its immediate results are not so apparent, its final consequences are more injurious. It may serve to temper our judgment of the slower East to notice how far imitation rules the iife of our own community. 


\section{The Factor of Invention.}

The faculty of imitation gives the clue to the formation of social ideas, but it does not explain how these ideas are changed. This is secured by invention. We are familiar with inventions in machinery and understand that a machine is an idea embodied in wood, or iron. This idea put into the form of a machine has the same effect as an idea elsewhere, it drives out imitation at that point, by making the old idea out of date. When Ericsson invented the Monitor the wooden vessel as a fighting machine was laid aside. For war purposes it became so much waste timber. When Whitney put his idea into the machine to gin cotton, it not only threw out the old methods, but it revolutionized the ideas of the South in regard to slavery, preparing the way for the Civil War. Inventions in philosophical and economic ideas also work changes in the same way as in machinery, though it is not so easy to trace their effects.

The more progressive the society, the more readily does it welcome the invention, or better, the less it opposes it. New ideas are always opposed and their proposer is not infrequently sacrificed to the idea of imitation, because the individual and the society refuse to make the reconstruction which the new idea would demand. The ideas presented by Jesus demanded then, and demand still, the entire reconstruction of our ideas and institutions, therefore they are rejected. The social mind has need of the faculty of imitation to give stability; it needs the faculty of invention for the sake 
of growth. The problem is to give each its proper place and function, so that neither will be in excess.

\section{The Social Imagination.}

Mr. Lester Ward in his "Psychic Factors of Civilization" takes the ground that society is still governed by instinct, not having reached the period of reason. Now while it must be aimitted that the social mind is not always reasonable, it is still maintained that it is given to reasoning, even though this is not the phase of mind which is most prominent. The State is more affected by imagination than by judgment. Louis Fourteenth, though his whole life was acted in public, was able to impose upon the imagination of his people so that he passed as a man of imposing stature, though he was, in fact, a little man. Napoleon First owed much of his success to his ability to appeal to the French imagination. In the battle of the Pyramids he reminds his soldiers that forgotten centuries look down upon them; at Tabor he recalls the Transfiguration.

A more recent evidence of the place which the imagination has in the social mind, was the ceremony in the coronation of Edward Seventh. To one who has not breathed the atmosphere of the traditions which cling about royalty and a titled nobility, there was much in the details of the proposed ceremony which seemed a proper setting for a comedy; yet for the mass of the English people even the carefulncss which prescribed what each actor was to do, appealed strongly to the imagination. If the king would drive to Westminster 
and assume the crown with as little ceremony as the American President takes his oath of office, he would lose a part of his hold upon the people. As soon as his subjects begin to weigh his abilities and his character as they would those of other men, his function is at an end. Measured by such standards, he might well exchange places with some of his subjects, and such would be the conclusion of reason. But imagination clothes him with a divinity not pertaining to ordinary men.

It is to call out the imagination that the king must demand certain dress and ceremony in his court. Should he allow his subjects to approach him as other men, the royal family would need to seek some other occupation. It is said that the courtiers of Louis Fourteenth did not venture to look above his shoe ties, and when they reached intimacy with Louis Sixteenth they sent him to the guillotine.

Bagehot says somewhere that the royal family is worth all it costs the English exchequer, because of its influence upon the order of the people. For the statesmen who wrangle in Parliament, they may lose respect, since these appeal only to their reason; royalty, which rises superior to debate, in whose name all acts of Government are performed, appeals to the imagination. The most violent agitators who air their grievances in Hyde Park, cease their denunciations of governmental faults to salute, with lifted hat, the member of the royal family that passes by.

One needs only to point to the crowded theatres to 
prove that imagination has a large place in the minds of the American people. While other meetings are poorly attended, the theatre, which makes no demand upon the reason, which seldom appeals to conscience, ministers to the demands of the masses of the people. Socials Habits and Ideals.

Habit is the static element in society; ideals are the dynamic. If the former is in excess we have social stagnation; if the latter, there is social unrest and revolution. Habit is the result of "imitation which leads men to think and to act alike.

Habit conserves social energy. It is a fact to which our nervous system bears forcible testimony, that while frequent changes of program add to the interest of our work, that it is gained at the cost of nerve force. There is no way in which work is done so easily as when reduced to routine. To eat, to work, to sleep regularly, is the price we must pay for continued vigor. As the musician strives for control of his instrument, his fingers become weary under the continued strain, but as the routine of fingering is acquired, the movement becomes easy. So easily is the movement executed that he is able to think of other things during the performance. That is the value of habit. It makes the performer a specialist in one kind of work.

The same thing is experienced in social duties. When society is used to doing a certain thing in a certain way, the work is done with a minimum of effort. It is the universal custom in the United States that when two 
carriages meet on the road each driver shall turn to the right, and it requires no thought on his part to take that direction. But if he were to take a drive in England, where it is customary to turn to the left, it would require continual attention to avoid a collision. It would cost no little time and trouble if this question of direction had to be decided whenever two carriages met on the road.

A leading reason for the unrest in the labor field is the unsettled condition of machine industry. Inventions in machinery have been so common and the changes introduced have been so radical, that workmen scarcely get adjusted to one condition when it becomes necessary to meet another. By a new invention the capital fixed in certain forms becomes antiquated, the skill which workers have acquired becomes useless. The continued throwing of machinery into the junk heap, together with the displacement of the worker behind it, are the common features of our feverish competition. The Trust introduces additional complications by its buying up of plants and leaving them idle to force up prices, or by running this one or that one as it may be desired to coerce the workers in particular places into submission. This makes a settled home for the worker an incumbrance, since he must follow his work, changing the workers into a restless, roving population. We are in need of industrial habits. Mr. Herbert Spencer is of the opinion that we are approaching a static condition in industry when invention will cease, and the different factors in the situation have an opportunity to adjust 
themselves. There is little present indication of such a condition in the future.

Another advantage of habit is that it not only enables us to do our work easier, but it makes possible a larger output. A machine produces a large amount of goods because they are all of one pattern, but it can not make any other kind. The more a man gets to be like a machine, the more work he can do of a certain kind. But it may be questioned if we want men to be like machines, even with the advantage which it gives in production. Machines are not ends in themselves, do not grow. Men are ends in themselves and are designed to grow forever, therefore habit needs some corrective, if development is to have a place. The State needs habits, needs to specialize in certain lines, but it must also universalize. It is to provide for this universalizing process that social ideals are essential.

The relation of habit and ideal is of that which is, with that which ought to be. The ideal is the view of the universal; habit is the older ideal realized in practice. Progressive society is continually moving from the special to the universal; from the actual to the ideal. In view of the fact that there are various ethical theories, it will be advisable to examine some of them in order to gain a clear and adequate definition of the ideal.

Kant held that the universal was the ideal, and this universal was reason. As this reason was in every man, it was the law to each, the standard of his conduct. To follow reason was righteousness; to fail was sin. 
Now it might seem that Kant had set to man an easy task, since it was to obey a law within himself, but there was another part of the self which refused this obedience. This was man's senses, or feeling, which was particular. Thus reason was set over against feeling; the former admonishing the man to follow a universal law, the latter to satisfy his particular feeling. Kant held that the opposition between these two parts of the self was so complete that no reconciliation was possible. Having thus split the individual into two warring sections, he found no way to gain peace except to exterminate one of the parties to the conflict. He therefore declared that feeling must be entirely disregarded, and reason implicitly obeyed.

The test of the rightness of an act lay in seeing whether it might be made universal. One should do only those acts which he would have all men do. If it would be right for all men, then it would be right for the individual, otherwise the act must be rejected. When I do an act, I therefore legislate that all should do it, so that I universalize the act. Duty should be done, not because we have a desire to do it, for that would vitiate the act, but solely for duty's sake. If a mother tended a child because of her love for it, the act would not be good. She must do it solely because it is the right thing for all mothers to do. All feeling must be eliminated from the good act, and the law obeyed solely because it is the law.

The Utilitarian thinkers took the other horn of the dilemma by claiming that feeling was the sole guide to 
duty. Pleasure, for one or the crowd, was the good. Whatever gained pleasure was labeled right; whatever did not gain pleasure bore the brand of wrong. As all must admit that what is pleasure for one person, or at one time, may not be pleasure for another person, or for the same person at another time, the Utilitarians could not claim to be following a universal law. His aim had, in the nature of the case, to be a particular pleasure, since pleasure is not a universal. The result of the Utilitarian theory is to make the character of the act independent of the character of the actor, since the only criterion is the resultant pleasure or pain. Now by combining the truth in these two extreme statements it may be possible to get a correct ideal.

Neither theory takes the whole man into account; Kant leaving out feeling, thus making action impossible, the Utilitarian leaving out reason, thus affording no rule, or law. As against the former it may be said that without feeling there would be no act; as against the latter the act would be without an aim. A true theory must take in the whole man without leaving out the part which does not seem to fit the conclusions, just as the mathematician is not allowed to eliminate some of the factors from his problem for the sake of simplifying it. The whole man must be included, and each element given its proper function.

With Kant we may hold that each mind has within it a universal element, which is the sum of truth already revealed, but against him, that this truth must have an interest for the mind, if it is to move to action. The 
difficulty with Kant was that he made his ideal abstract, when he expurgated feeling. The ideal is not something away from the self; it is the self idealized. We may say that the ideal of the Christian is Jesus Christ, but, more exactly, it is the Christian himself acting as he thinks that Jesus would act in his place. "What would Jesus do?" is his problem. When one takes Webster as his model, what is really in his mind is himself holding an audience as he understands that Webster did. When he has an ideal of an engineer, it is of himself running an engine. What is in his mind is himself acting as this other one acted. The soldier sees himself returning from the war, receiving the applause of the crowd. Make the ideal abstract as Kant did, and it is robbed of interest. Make the ideal after the Utilitarian fashion and it has no value.

The ideal of the individual is himself fashioned after his conception of Jesus, filled with an absorbing interest to realize this conception in the practical duties of life. The social ideal of the Christian State is the State acting according to the Spirit of its Lord. The individual ideal takes in the whole man in his every faculty. "When He shall appear we shall be like Him." This is the universal which each should seek to realize in himself, thus becoming universal as $\mathrm{He}$ is. The Christian social ideal is the acceptance of the same aim by society.

With this explanation, it is easy to see the conflict between habits and ideals, the former constraining men to follow old customs, the latter demanding new standards of living. Against the realization of the social ideal 
are ranked its determined opponents and the mass of indifferent citizens, who are inclined to follow the path of least resistance wherever it leads. The latter class must be roused to an interest in the ideal before it can be realized in the social life. This requires the breaking of old habits.

As in the case of the idea, the ideal reaches the social mind through individual initiative. It was only as individuals like Cobden and Bright felt the injustice of the Corn Laws, and set before their minds a vision of an England whose laws would not favor the rich as against the poor, that they were able to put their ideal in the public mind, and compel the repeal of the unjust measures. This transference of the individual ideal into a social ideal is the end of each reformer. If he is able to project his thought into the common mind, he wins his case; if it remains only an individual ideal, he suffers defeat. His success depends on three conditions; the earnestness with which he puts himself into his cause, the value of the cause itself to the public weal, and the thoroughness with which the opposition is organized

Wonder is sometimes expressed at the success which some missionaries meet, while others, with an equally earnest presentation of the same truth, reap but little fruit from their labors. Missionary Paton, with those who went before, and followed him, has been able, in large measures, to Christianize certain islands in the New Hebrides, while equal labor elsewhere can not boast a hundred corverts. In this case the opposing 
forces were not organized. Had they been followers of Mohammed, or Buddha, with a definite belief, quitc other results might have been recorded. Impressionable minds were found in the New Hebrides to which the ideal could be transferred.

The usual difficulty which the exponent of an unpopular truth has to face, is the indifference, rather than the opposition of his fellows. They may be ready to admit that his proposition satisfies the Kantian demand of being universal, but they have little or no interest in its realization. In some way the feeling must be touched so that interest may be roused in the proposed reform. Until this is realized it is not an ideal for them, even though they admit its rightfulness. It becomes an ideal only when it moves to action for its realization. Lacking this interest, it remains an abstraction to the citizen.

There are two things that aid in forming a social ideal, the logic of argument and the logic of events. The logic of argument sets the intellectual phase of the ideal before the public mind, but most frequently is not able to do more. It requires the logic of events to prove to men that they have an interest which should enlist their services in the settlement of the question. It is some consolation to the advocate of the unpopular truth to know that history will record the completion of what he has begun.

It has already been suggested that there is a measure of pain in the reception of an idea, and much more is this true when an ideal is the issue. That means not 
only a new intellectual adjustment, but a new standard of conduct. It is of vital importance that a people should have an ideal, since without it they might not pass from barbarism to civilization, indeed, without an ideal they would not constitute a people. It is the ideal which gives them unity of purpose and of action. It may provide for but a limited development, as did the culture of Athens, the might of Rome, or the victories of Mohammed; or, it may furnish a ceaseless incentive to growth in the realization of the teachings of the Christ. But whether it is low or high, whether it provides the dynamic for limited or infinite development, an ideal is an essential of national existence. Happy is that people whose pure ideal ever inspires heroic effort like. a trumpet call!

Peoples have grown old and died because they reached the bounds of their ideals. They reach the point where they cease to grow, and enfeebled age ends in death. With the loss of ideal, all social institutions begin to lose vitality. The people loses more and more of the quali. ties which gave unity and vigor. In the midst of this social decay the intelligence and genius of individuals may still increase, but it only lights up the general decay. With the failure of common aim, control passes into the hands of individuals who vainly seek by artificial bonds to hold society together. The people has become a crowd of individuals, without purpose or future. LeBon closes his suggestive book on "The Crowd" with this sentence: "To pass in pursuit of an ideal from the barbarous to the civilized state, and then to decline and 'die, such is the cycle of the life of a people." 
Such is the conclusion of M. LeBon, living in the midst of a people which has lost its old faith and failed to find a new one. But if the people retains its faith in a noble ideal such as the New Testament sets before men, it will continue to give inspiration and aspiration, increasing in force as the ideal is realized. The American patriot can scarcely listen without anxiety to the popular speech, which seems to find the American ideal in the Moloch of commercialism.

2. Social Feeling.

We get an insight into M. LeBon's pessimistic views of the social future, when we remember that he believes that modern society is largely under the control of feeling. In former times the traditional policies of the European Governments were the factors which shaped the course of political events, but now, he declares, the actual control is the voice of the masses. Kings have only to listen and obey.

So far the reader with a democratic leaning would cheerfully go with M. LeBon, but the danger which this author sees is that the intellectual factor has so small an influence in the social mind. The passions of the mob are in control. We may hope that the condition of France furnishes greater support for the celebrated author's thesis than would conditions elsewhere, yet as the Englishman recalls the London celebrations of the relief of Mafeking and Kimberley, and as the American reads his weekly account of horrible executions by the mob, it does not appear that others have great cause for complacency. 
Yet in spite of the contention of many writers, with due regard for the passionate outbursts which are brought so frequently to our notice, taking into account that civilization is frequently only a conventional fig leaf for the "form of tiger or of ape," yet it may be maintained that though feeling is dominant, intelligence is not eclipsed.

A ready illustration of how feeling becomes the dominant factor in the social mind is found in the incidents following the blowing up of the Maine in the harbor of Havana. In the midst of the investigation of the location of the explosive which wrecked the vessel; in disregard of the assurance of Minister Woodford at Madrid that the whole affair, even to the granting of independence to Cuba, might be settled by diplomatic methods; in opposition to the wishes of the President, the passionate demand for revenge hurried the country into war. This course forever shielded the authors of the outrage and brought the penalty upon those who were innocent of the crime. It was one of the occasions when reason was set aside and feeling ruled the hour. This is evident alike to those who approve and those who condemn the declaration of war. Feeling at times gets at right conclusions when reasons hesitates and fails, but unmediated feeling is not a safe guide.

Feeling holds a larger relative place in childhood than in later years, and the same development of rationality may be noted, unless in exceptional cases, among progressive peoples. Such a movement as the Crusades would be an utter impossibility today. Incleed it is quite 
impossible for us to place ourselves amid the Crusaders' surroundings and understand how the peasants and the kings, the feeble children and the scarred warriors were alike seized by the impulse to place the cross upon their garments, if not in their hearts, and hasten by land or sea toward the Holy Sepulcher. Nor was it a single impulse, since it held the attention of Europe during three centuries. It was a strange waste of life and treasure to gain an empty tomb when its living occupant was as surely present at Paris as at Jerusalem. But even though the object sought was of little value, yet it was well that Europe should be united for any common purpose other than "beauty and booty." The theological age has passed in which it was possible to excite a common interest for such an end as the winning of a tomb.

The recent death of Queen Victoria awakened a common feeling of sorrow through a great part of the world. Her long reign, her worthy character, the apparent fact that her life was shortened by her sorrow on account of the war in which England was engaged, all united to enlist a common feeling of sympathy. The distress of the people of India through the famine, appealed to the sympathy of all classes in many countries, and moved men to make provision for the starving peasantry. Events such as these have effects that are not limited by political boundaries and indicate the kinship of humanity. But as is usually the case, the extension of the feeling lessens its intensity.

Neither of these events caused the deep grief in 'America which was felt on the death of President Lin- 
coln. But a few days before, the people had rejoiced over the end of the most terrible of modern wars but before the news from Appomatox had become a commonplace, the smiles were changed to tears over the death of the man with whom they had waded the deep waters of the Civil War. The sorrow was greater through the preceding rejoicing. Our country never mourned so sincerely for any man as for the one who lies at Springfield. More than other men, in his birth and in his life with all its trials he had been one of the people. The defeated South mourned, as it had lost, a friend. Joy or sorrow is not life, but only the expression of it and where there is found a community of feeling it evidences a common life.

Feeling is contagious. If one wishes to communicate ideas it is best done by close contact with a few ; feelings may be reached most easily in the crowded house. Not only is the feeling passed like an electric shock from one to another, but it becomes more intense as it spreads. Men will be moved to action in the crowded audience which they can scarcely explain themselves in cooler moments. It is for this reason that a community resolves itself into a mob and perpetrates acts which would shock the most hardened criminal in the neighborhood. Some of the mob which spread terror through the streets of Paris in the Revolution were gentle and inoffensive at other times. The feelings of the crowd had transformed them for the time. It is said that at one of Whitfield's preaching services, where an immense aúdience had been gathered in the field, a woman was found 
on the outskirts of the crowd, weeping in sympathy, though beyond the reach of the great preacher's words. On being asked why she wept when she could not hear the sermon, she answered that it was because of his holy gestures. The fact was that she had been moved to intense feeling by the feeling of the crowd.

The criticism has already been passed upon the ethical theory which finds its criterion of conduct in feeling, that it really leaves us without any standard at all. Feeling it fitful. When the English rang the bells of London to express their joy at the declaration of war against Spain in I739 Walpole said: "You are ringing the bells now, but you will soon be wringing your hands," a prophecy of speedy fulfillment. One may see a missionary pleading the needs of the heathen in a way that brings tears to the eyes of his audience, and notice the emotion disappear on the approach of the collection basket. Feeling which finds its end in itself, as such emotion does, has no social value. There can be no action without feeling; there can be no direction of the feeling without ideas.

A common feeling may lead to deeds of heroism, or to the most abhorrent acts. The members of the French aristocracy, who had held tenaciously to every privilege gained through the centuries, acted as one man in their surrender of them all on the night of August Fourth, I789, not, probably, because all were ready for that sacrifice, but because of the feeling of the moment. The contagion of the act swept away individual scruples in regard to it. One who has felt upon him the magnetism of a 
great crowd, can understand how it would lift or lower him beyond himself. It is very difficult for the individual to resist the feeling which obtains in his time and country, and it is done at great personal cost.

\section{The Social Will.}

It has been already stated that knowledge, feeling, and will are the three phases of mind, which, for purpose of analysis, we look at separately, but which are always one in fact. It is in point at this stage in the discussion to notice the place of each. Knowledge is the objective, the universal element, since it is everywhere and open to all. Knowledge is finally truth, which has no boundaries. Feeling is at the opposite mental pole from knowledge. While all societies and all individuals may have the same knowledge, each individual and each people has a feeling not experienced by any other. Thus feeling is subjective and particular. But if we stopped with these two elements, the universal and the particular, the objective and the subjective, we would not have the elements that make up conduct. These two elements must be brought into connection. This is the function of the will.

The will mediates between these two phases of the self, and unites the self in an act. The idea by itself would have no force; the feeling by itself might give movement but not conduct. It is the will which brings the whole self together and puts it into the act. Hegel treated the will as the self, but it may readily be seen that it is that phase of the self most prominent in the act. 
The respective functions of knowledge, feeling, and will may be easily grasped by considering the psychology of an audience. The speaker presents certain ideas which he wishes the audience to accept as true, but it is possible to have gained this much without advantage either to speaker or audience. It is the hope of the speaker that his thought may be so vivid that it will awaken a feeling, create an interest in the idea as something of value to them. But it is possible for the speaker to awaken feeling without the completion of an act. Many men have wept for the faults which they did not will to give up. It was once said of Henry Clay that he could win more cheers and fewer votes than any other campaigner of his day. What is yet lacking is that the will shall couple the idea with the feeling, resulting in a deed. It is true that failure may intrude at any one of these three points. The people may fail to get the idea, getting the idea it may have no interest for them, even with this interest it may be of too weak a nature to lead to the willing of an act. The one who would move the social mind to deeds, must have in his own mind the psychological process which must be gone through.

This process finds some illustration in the present stage of the saloon issue. For many years the temperance advocates have been presenting facts and arguments so that the social mind might not lack for knowledge of the subject, and while feeling has been stirred on the matter it has not become an issue in which there is deep and general interest. Reformers are some times blamed for the terrible pictures which they draw 
of the consequences of social vice, but they are seeking to induce social feeling without which there can not be social action. It is necessary that the State should feel, and feel intensely on the subject before the abolition of the saloon can be willed. Many individuals have thought, and felt, and willed already, but the State has not.

This psychological process suggested here is what is known, in common speech, as making up one's mind. In the case of the individual, this usually takes so little time that we are scarcely conscious of any psychological process, but the social mind does not so quickly arrive at conclusions. The debate on the question of slavery in the United States can be readily traced during a century, though it could not be called an issue more than one-quarter of that period. The discussion of the larger issue of the liquor traffic goes back to the earliest records, but has been a political issue in United States for fifty years. It may be said that the State has willed the license system as a settlement of the liquor problem, but since so many citizens refuse to accept this settlement as final, the social mind is urged to other conclusions. Many of the acts of the State are subconscious, that is, they have been worked out in individual minds, but the social mind has not gone through the process. We may fairly view the act as socially subconscious when certain individuals prepare the issue, select the candidates, and then, by means with which we are familiar, gain a ratification of their work by the public. It is a kind of political hypnotism in which the "boss" tries to keep the public from seeing the real issues of the moment, 
by appeals to partisan prejudice, or other means to gain his end. An able English publicist has recently congratulated us on the campaign of 1896 , in which, as he thinks, the people were instructed in a very difficult economic problem so that they were enabled to reach a right conclusion. Now while we would fain take to ourselves all the praise which our English admirer gives, justice demands that we should confess that the public know but little of the merits of the money question even yet. The most difficult subject with which the trained economist has to deal, can not be explained to an average audience in an hour amid red fire and torchlight processions. Whether one approves or disapproves the decision of the campaign, he will scarcely hold that the public were thoroughly instructed on theories of value when he recalls the character of the discussions in the press and on the platform.

When the social mind consciously chooses all the ends of action, there will be no more place for the machine politician. His object is to direct social energies to the accomplishing of private ends, and when the State becomes thoroughiy conscious of itself in its acts, it will not minister to individual ends. We have specific prohibitions of class legislation in some of our Commonwealths, yet most of our laws are made by and for a class. The occasional revolutions which take place in political campaigns, which result in the dethroning of some poitician, come about through the conscious action of the social mind. The reason why such movements bear little fruit is that the mind returns to subconsciousness. 
The will of the State, which is a recognized fact even in popular speech, is an evidence of the spiritual character. of the State. It is because it has a will that it has responsibility, and is held to account for its actions both at home and abroad. It is, then, the chief interest of the patriot to educate the social mind so that the will of the State may be brought into loyal concurrence with the will of God.

The Crowd, Le Bon; Psychology, Dewey; Social and Ethical Interpretations, Baldwin; Psychic Factors of Civillzation, Ward; Democracy and Empire, Giddings (pp. 27-67); Introduction to the Study of Sociology, Stuckenberg (pp. I15-233); An Introduction to Sociology, Fairbanks (pp. 76-9I). 


\section{THE SOCIAL CONSCIENCE}

Professor Dewey has defined conscience as the intelligence applied to moral questions. Conscience, by this definition, is not some separate faculty of mind, nor is it a peculiar kind of mental activity. Conscience is character, the intelligent self, deciding moral questions. Mental activity comes properly under the name of conscience when questions of right and wrong are involved in the subject-matter. For instance, social intelligence, which always includes all moral attainments, is concerned in the determination of the time of an eclipse, but that forecasting is not a matter with which conscience deals. But if, on the other hand, a matter of human welfare was at issue, conscience would come in as a factor in the settlement of it.

From this it is evident that the growth of social intelligence will make greater demands upon conscience. In the older and more simple forms of society, their problems were mainly of the neighborhood, since they knew and cared little for the larger world beyond the horizon. In the complexity of modern life, where the division of labor has made us dependent on a thousand agents for our daily food, when each man becomes a producer for a world market so that he is involved in questions as universal as human kind, conscience is called into continual activity. When occupations are few and each 
man produces what he consumes, daily life becomes a routine of duties into which conscience scarcely intrudes. The habitual ceases to be the conscientious and if it were possible to reduce action to the simple repetition of identical acts, conscience might retire from the field of social control.

\section{Conscience and Habit.}

Some attention was given in the discussion of the social mind, to the value of habit in giving ease of execution. It is for this reason that division of labor, which makes the specialist possible, increases mechanical efficiency. A few cities of Massachusetts have specialized in the shoe industry so that the artisans have special capability in the making of shoes. Instead of having to consider each particular act in the process, it has become a routine which they can follow, for the most part, mechanically. Now it is suggested that this illustration from the factory shows how moral judgments are reduced to routine. In any community the major part of the acts have been repeated so often that the question of their rightfulness is not raised in the mind when they are performed. One ceases to reflect upon a moral act, just as upon a mechanical act, when it has become habitual. It is in this way that a community becomes specialized on a certain kind of moral judgment. When the act was first performed, conscience would be operative, doubtless some question would be raised during its earlier repetitions, but later it is done as a matter of course.

The advantage of habit in the making of shoes has its 
correspondent advantage in the passing of moral judgments. If each particular act in process of shaping and sewing the leather had to be turned over in the mind, it would result in reducing the output of shoes; also if the individual had to reflect upon each act which he performs in the sphere of morals, he would not accomplish much. There is need for moral habits in which conscience is mainly inactive, as well as for habits in other matters. When the individual analyzes his own conduct he finds that by far the greater part comes under habit. This means that he is a specialist in certain kinds of moral judgments, as the factory hand is in the making of a certain article.

While this has its advantage, its disadvantage is no less evident. So long as the mechanic finds occupation in that line in which he has specialized, all goes well; but the time comes when a new position must be taken, and new methods used, which he must learn. So the individual, who has followed a routine of duty, finds a new situation; he tries to meet it by the old rule, but something tells him that his act does not meet the situation. His new intelligence shows him a broader field, a more complex situation than he had known before. Conscience is calling upon him to take in a fuller meaning of the act than before, to generalize instead of specializing.

\section{Conscience Generalizes.}

There was a time when men conscientiously thought that slavery was right, that they did their whole duty 
when they fed and clothed the body of the worker; but the time came when they learned that the spirit in that body had to be considered. New knowledge of the facts in the case demanded a new line of conduct. With the former knowledge, the old habitual conduct had passed without question; the enlightened mind condemns it as wrong. The old was too narrow, too specialized, to fit the present demands. The faulty act is the one which fails to take into account the whole individual, and the whole situation in which he acts. A perfect knowledge of self and of the whole situation, combined with a perfect adjustment of the self to the situation, would result in perfect action. A failure in either of these respects leaves the resulting act defective. Specialization reduces our conduct to routine, and saves us the trouble of thinking out each particular act; yet unless some corrective is introduced there could be no progress in life. Conscience furnishes this corrective by showing that the former acts were based upon a partial understanding. It is the rebuke of the broader life to the narrower, of the new ideal to the old. When the new standard of action is accepted, and conduct adjusted to it, then a habit is formed on the new plane of action. Thus, unless the life is to become fixed, it is necessary that increasing intelligence of duty to God and men should continually act as a rebuke upon the past life. In this way the individual is brought into the higher and broader view of life.

This may have concrete illustration in the growth of conscience on the question of temperance. It is within 
the memory of those still living that liquor found its place upon the table and in the closet of the most conscientious people. According to the intelligence of the time, this conduct appeared commendable, therefore it became habitual. But as the evil results of the drinking habit were more clearly seen, these results were taken into consideration when the matter was thought over, and as a result a large class became total abstainers. At first this required some struggle on the part of the individuals who thus took the broader view of life, but with the years, total abstinence became as firmly fixed as a habit, as drinking had been before.

Then the penologist investigated the causes of crime, tracing the greater portion of it to drink; the economist showed the immense waste of wealth by the same agency; the scientist demonstrated that alcohol was a poison,all these facts were brought into the individual intelligence causing him to decide that his course of action had been faulty. Now conscience incites him to insist upon the social prohibition of the traffic.

This shows how conscience gains the broader outlook and insists that conduct shall conform to it. The new outlook is in fact the new self, which condemns the old self of yesterday. The old act, probably, seemed right at the time, but with the new light it is seen to be wrong. Conscience is the moral dynamic in life. It moves the world.

The Social Conscience.

Some space has been given to the discussion of the 
individual conscience because it provides an easy in. troduction to the study of the social conscience. In both cases, the individual and the social, the elements to be considered and the process of getting results are the same. In society a social judgment affords a precedent for like judgments on similar cases, and a social habit is formed. This is the conservative element in the social life. But as the social mind develops in knowledge of social responsibility and of the field of operations, the old habit is seen to be defective. It fails to satisfy the conditions. The social conscience now insists on the correction of social habits up to the new standard. The social conscience of the English people judged a man to the gallows two hundred years ago for stealing a few shillings; now the life of the accused is carefully guarded by the jury trial, even when human life has been taken. The social conscience approved the execution of the man who stole a sheep, then, as certainly as it approves today when he has been convicted of murder. The fuller knowledge of the value of human life has given a new standard to the social conscience.

The difference is that the case of the criminal is looked at now in a more universal way. In former times he was seen only in one aspect,-as a disturber of the peace that ought to be gotten out of the way; while the growing intelligence has discovered that each individual has a social value, and also that society, which has furnished the environment of the criminal, is in part responsible for his fault. The social conscience would now revolt at an action which was thought commendable in former 
days. All this means that society is gaining a more universal view of the act.

The time will doubtless come when it will be seen that the idea of licensing the sale of liquor and then the punishing of the man who commits a crime under its influence, is an exceedingly narrow conception of social duty. As a matter of fact, each act has a universal character when we are able to see it in all its bearings. In our lack of intelligence we look upon it as unrelated; yet if society is organic, the act has vital relations to the whole universe in which it takes place. To perform the act perfectly it must be understood in all these relationships, so that perfection belongs to God only, since $\mathrm{He}$ alone has complete knowledge; but the individual and society are alike under orders to gain the universal view. "Be ye perfect as your Father which is in heaven is perfect."

Selfishness is sinfulness, since it consists in getting a narrow view of the act, or, what is the same thing, in getting a narrow view of the self. Very much of the statute law of the different States of the world is vitiated by this fact. It is drawn in favor of a particular class within the State, or it is drawn without regard to its effects on other States, yes even favored because it will injure other States. One would need only to look over the records of Congress to find certain laws favored because they would injure foreign workmen, therefore, wonderful to relate, they would benefit our own. Specializing has its place in ethics so that we may form habits, but we are in no danger of having too few. 
The defects in social conduct are due to the lack of generalization. Society fails to take in the whole situation, therefore social action is partial in character. The Tribal Conscience.

The difference between the tribal conscience and what has been treated in the preceding pages as the reflective conscience, is mainly in the place which the ideal occupies. The reflective conscience, whose ideal lies in the future, makes its appeal to men to change their conduct so that it may agree with the broader view of life which intelligence has gained. The tribal conscience, which has its ideal in the past, makes its demand upon present conduct to conform to the past. The reflective conscience was not an important factor in the social movement until it was trained by Christianity; the tribal conscience was prevalent under the heathen faiths.

Between these two conceptions, the ethics of the present day seems to be seeking a middle ground in the idea of natural selection, which insists on conformity to the things as they are. In this last view the ideal is the actual. In the case of the tribal conscience, the ideal is the ancient, so it was that the Greeks looked backward to the Elysian Fields and the time when the gods walked upon the earth. The reflective conscience insists that the ideal has not yet been reached. It is the ought-to-be.

Thus we have the three ideals of the past, the present, or the future, as the dominant influence upon the conscience at each of the different periods in history. This gives us three conceptions of duty; to conform to what has been, to what is, or to what ought to be. 
It has been said that order is Heaven's first law; it certainly is man's first need. It is for this reason, doubtless, that some form of government always exists, however intolerable it may be. Order must precede progress, since it is essential to have something secured before it is possible to strive for anything better. Plato was willing to sacrifice important social interests for the sake of gaining order, even though it meant much loss in other regards. In the Grecian and the Roman systems it was believed that the existing state of things had been sanctioned by the gods; therefore it was sacred. He that proposed change was liable to be charged with impiety.

The king, the priests, the customs of the people, each and all rested on the will of the gods, without whose direction through the auspices, no important work was undertaken. Under such conditions the citizen did not presume to criticise the laws, and Socrates does not question the justice of his death sentence because he was a bringer-in of strange gods. According to the tribal conscience such a deed made the doer a public enemy, since he justified the wrath of the gods against his native city.

\section{The Place of the Individual.}

The age had little place for the individual, even less for individual opinion, since it was the proper thing for each man to think as his fathers thought. He must stand with his face to the past and reproduce their conduct in his own life. Uniformity was the divine and 
human order of the day. Bagehot calls this the period of nation-making, when through the habit of imitation each individual was a reduced image of his community, the community only a larger man. For individuality there was little provision. It is for this reason that the tribal conscience, though it served a temporary phase of the social need by inducing order, becomes a hindrance in later times.

The reason for this is that while the tribal conscience provided for order by compelling uniformity through devotion to the past, it by this very means barred the road of progress. It gained law, but shut out freedom. The law and the legal procedure had been given by and for the aristocracy, and since it was at the same time secret and sacred, the ordinary man was helpless. No matter what conditions arose, the individual had to be judged by the old law.

When the English wished permission to begin an irrigating system in India, the improvement could not be allowed by the Hindoos till some old phrase in the sacred books was twisted into an endorsement of irrigation. Nothing must be done that is not sanctioned expressly by the religious authorities. When any such crystallization of custom is secured, it means the perpetuation of whatever class is in power. This is but another way of saying that wherever the tribal conscience is dominant, aristocracy will be perpetuated. Ice will not form where water is in rapid motion, nor will an aristocracy, gain much power while social conditions are mobile. Any influence which tends to fix social condi- 
tions, changing them from the fluid to crystallized form, furnishes the conditions in which aristocracy flourishes.

Under such a social order, the individual had an importance only when he was fortunte enough to belong to the aristocracy. So long as things could be kept as they were, the favored few could keep their special privileges. Christianity came in to teach that each man in himself, regardless of the class in which he was born, had an infinite value. Civilization since that time may be measured by the degree in which it has appreciated the weakest man. The strong can always have consideration, and need no safeguard; Christianity has its social value in the fact that it appreciates the weak things in life.

\section{The Christian Ideal.}

The aim which Christianity set for the social conscience is the glory of God and the weal of man. Such an ideal, if faithfully followed, makes a social aristocracy impossible. The ancient religions had fostered aristocracy, since they proposed a fixed ideal - an ideal which was already realized. This made no provision for future development. Christianity provides no station where the individual or the society can stop, with the certainty that God has his due of glory and man his share of weal. Unceasingly, in the progressive State, does the social conscience call upon men to take a higher conception of what the glory of God and the welfare of men require. It is this which makes aristocracy impossible, and democracy inevitable in the Christian order of development. The Christian ideal allows for no pause in 
the movement toward the thorough appreciation of "the least of these, my brethren."

It is sometimes said that the glory of God is an abstraction which can not be used to define conduct. Rather should it be said that it affords the standard by which to measure human well-being. Men are not agreed as to what constitutes the good of man. One set of reformers, the Socialists, identifies social weal with the abundance of material goods, and insists on the public ownership of the means of production, in order to bring about this economic change. Another school, which makes wealth the end, contends that the Socialistic method would mean the undoing of society. Others claim that the social weal does not consist simply in an economic surplus, but rather in a higher spiritual life. These, and many others that might be named, are all aiming at the social improvement, yet there is a lack of agreement as to what the social welfare demands.

It is at this point that the duty to God defines our duty to man. Would the plan of the Socialist, the Anarchist, or the Single Taxer, give glory to God when carried to its fruition? If no one of these would gain that end, then no one of them can be an end toward which men should strive. The ideal is not simply economic. The change is not alone in economic methods, but in spiritual life. It would be possible to find out in the costly school of experience the worth of any of the various panaceas that are offered for the curing of human ills, but the teachings of Jesus Christ have provided an easier way. It is possible to throw out all plans 
for social service which do not, at the same time, minister to the divine. The social ideal must be also the divine, as the social spirit is to be at one with God.

\section{Christianity and the Social Conscience.}

We are accustomed to think of conscience as the dynamic element in life, as that which makes us dissatisfied with what we are, in comparison with what we should be. Yet it is worth keeping in mind that this conception of conscience scarcely obtains except under the teaching of Christianity. One would not easily prove that conscience is a dynamic influence in India or in China, unless one would regard the force of inertia as dynamic. The social conscience in those countries puts a ban on progress.

The citizen of ancient Rome rose and ate, he sowed and reaped, according to the ritual imposed on him by the gods. This ritual was his religion, and his conscience demanded its strict observance. Whenever a people is ruled by a religion of ritual, instead of principles, progress is possible only at the expense of religion. Thus when the Plebeians wrested the law from the Patricians at Rome, it meant the decline of faith in the Roman religion. Principles of a high order such as Jesus taught, allow for infinite development; ritual fixes the society as it is.

While the Plebeian was excluded from religious privileges at Rome, he had no ancestors, because he had no ritual for their worship; he could contract no legal marriage, because he had no marriage rites; there was no legal relation of parents and children, since there were 
no religious rites in the home. When the Plebeians went out to the Sacred Mount to build a city, they found it impossible to draw its boundaries, or set its walls, through lack of gods to supervise the work. In that day, when the infidel was unknown, no one would have thought of founding a city except according to the ritual of the gods.

The doctrines of Mohammed were more flexible than the Roman ritual, so that the prophet was able to lift the tribes of the desert and weld them into a fighting force for the teaching of his creed; but the elasticity was slight, the development small. Their heaven hung so low that their heads soon reached it.

Buddhism did no better in furnishing a basis for conscience. It thoroughly depreciated the individual, so that he considered his life as of no value, looking for the Hindoo heaven in the Nirvana, where the individual was lost in the infinite. There is little incentive for the individual or the society to strive after better conditions when "the best of being is but not to be."

So one may run over the list of the religions of the earth, and find that in no one except Christianity will the conscience be trained to demand social progress. In no other does one find such expression from a devotee as that of Paul: "Forgetting the things which are behind, and stretching forward to the things which are before, I press on toward the goal." The social conscience is measured by the knowledge which the social mind has gained of Jesus Christ ; and as the Spirit leads into " more truth," the former view is dwarfed by the conception of 
a larger Christ, which society is impelled to realize in its institutions and laws. The Christ is larger than our highest conception of Him, so that conscience in the growing life makes ever new demands of growth. The individual, who must ever pioneer the way for society because he has a clearer vision of the Christ than that given to the mass of men, is under bonds to take the path which conscience chooses, blazing the road in which coming generations will walk. Olive Schreiner makes one of her characters say: "Where I lie down worn out, other men will stand, young and fresh. By the steps that I have cut they will climb; by the stairs that I have built, they will mount. They will never know the name of the man who made them."

\section{The Christian Conscience is Democratic.}

In popular speech democracy means scarcely more than universal manhood suffrage. That is one of the conditions of democracy, yet only one. Before the courts and the ballot-box each counts for one, but this equality is but formal so long as the line is rigorously drawn in the factory and the social gathering. The separation is not more distinctly made at the present day between employers and workmen, than it is between different classes of workmen. In our cities, and even in our villages, the dwellers on one street hesitate to elevate the less fortunate dwellers on some other street to their social peerage. We are many degrees removed from the extreme separations into classes: which deform the social life of India, doubtless farther removed from that democ- 
racy which distinguishes the Kingdom of God. Jesus defined the democracy which $\mathrm{He}$ came to earth to manifest by word and act when $\mathrm{He}$ said: "Whosoever will be chief among you, let him be your servant." In such a society the Plebeian and the Patrician, the slave and the Emperor, stand on a common footing. Paul had in his company philosophers from the schools, and the slave with the iron ring, which marked his station, about his neck, for the conscience trained in that discipline knew neither class nor caste.

Whether the ancient religions of Rome and India had forged the fetters of caste or not, it was certain that they lent their aid in keeping the shackles on. Once let the social conscience rest satisfied with things as they are, and no matter what stage of advancement has been reached, an aristocracy will be formed. The social conscience must be kept active if society is to remain in a plastic condition. Once let men feel that they are about as good as they need to be, and the wrongs of the oppressed appeal to them in vain. That is one reason why the periods of material prosperity are apt to be marked by social indifference to individual wrongs.

No State has yet appreciated the individual at the value which Jesus set upon him, though the intervening nineteen centuries have not left the individual as they found him. Suicide is no longer approved as honorable. It is related that when the philosopher Seneca learned that he had lost the favor of the Emperor, Nero, he invited his friends to a banquet and at its close calmly opened his veins as if life were of no account. When 
men held their own lives so cheaply, it need cause no surprise that the thousands were slaughtered in the arena for the pleasure of the crowd; nor is it strange that the populace should hiss the vanquished gladiator who presumed to beg for life, instead of quietly receiving the death-thrust. The malformed infant, once thought to be a social burden, is not now cast out to die, nor are the prisons of England such "vile dens" as when Bunyan saw them two hundred years ago. The individual seems to be coming into his own as Christianity works upon the social conscience to clear the way, yet one may read in the records of daily events the facts which indicate that Christianity is often but a veneer over the unregenerate savage of the former days.

The Separation of the Church from the Government.

This event was one of the ways in which Democracy was made possible. It has been already stated that in the ancient society, no line was drawn between the political and ecclesiastical institutions; they had the same official head, since the king was also a priest; they had the same sanctuary, the civitas

No clearly marked distinction was then drawn between the ecclesiastical and the political, with the possible exception of the Hebrew Commonwealth, until Jesus organized his new society.

Previous to this time the local religion had been used to sanction the existing political order; but the community of persons which Jesus formed about Himself was in direct antagonism to the political methods of the time. It is quite true that $\mathrm{He}$ refused to be a party to any 
insurrection against Rome, teaching the duty of submission even to injustice. Yet it would not be questioned that the realization of the principles which $\mathrm{He}$ laid down would have revolutionized any Government existing at, or since, that time. The organization which Jesus effected, with the twelve Apostles as a nucleus, and the Sermon on the Mount as a constitution, differed in its laws, in its ideals, and in its spirit, from the existing civil powers. Therefore it is clear that between this body, which was the germ of the Kingdom and the Church, and the Roman administration there could be no basis of agreement which would not have resulted in a fundamental change in one or other party. The sentence of death which Rome passed upon Jesus was the only logical conclusion from the premises. Pilate's bad record, which he feared to meet at Rome, his moral weakness in the face of the mob, were the immediate causes; yet back of these was the fact of an irrepressible conflict between the principles of force and love. The death of Jesus came in the logic of events. To the time it was the triumph of force; to the future the triumph of love.

Judaism and the Empire Were Aristocratic.

Jesus in His teaching had asked that a new valuation should be placed upon the individual, and to have granted it would have bankrupted both the Roman and the Jewish institutions of the day. There had been a time both in Rome and in Palestine when the common man had some consideration, but it had passed. The lust for power and gold at Rome had banished the old equality which 
existed among the simple peasantry which produced a Cincinnatus, to replace it by the rule of the men who had been enriched by the plunder of the provinces. Nor was the case otherwise in Judea, where it was thought that Jesus had forfeited his claim to respect by eating with "sinners." To accept the teaching of Jesus would require that the haughty Pharisee should be a friend to men regardless of their station, and that the Roman, who flung his slaves to the fishes on the slightest provocation, should become a minister to the lowly. For either Jew or Roman to have acted on this proposal would have overturned the existing social systems.

The new religion could not live at peace with existing conditions, so that instead of acting as a prop to the temporal order as heathenism had done, it undermined it. Both the Jewish and the Romans faiths had been understood to teach that righteousness consisted in repeating the past, by walking in the footsteps of their ancestors. Jesus taught through the medium of Paul, "old things are passed away; behold, all things are become new." It was this condemnation, passed by Jesus and his followers on past and present observance that brought about the new conditions. The old order could be maintained so long as it had the support of religion; but when that stay was removed, the individual freed himself from the old restrictions, "which neither they nor their fathers were able to bear."

Thus the Jewish and Roman institutions lost their sanctity in the eyes of the common people and were brought to the test of their fitness to benefit men. It was 
less now what was old than what was right, two ideas which had not been distinguished under heathenism. Thus when Christianity shifted the ideal of the Gentile converts from the past to the future, it broke the yoke of old customs, giving an affirmative impulse to the democratic idea which rated each man at an eternal value. The parable of the lost sheep was strange doctrine to the ancient world.

It was for these reasons that the growing antagonism between the Church and the Empire came to discredit the aristocratic order. By the customs of the time, men were rated according to the social class to which they belonged; Christianity insisted that each individual be valued as a man. It had been the former teaching that individuals existed for the sake of institutions, the individual for the State; Jesus taught in regard to the holiest of institutions that "the Sabbath was made for man, and not man for the Sabbath." To such an extreme was the dislike of existing institutions carried that the belief was prevalent in the Church of the early centuries that the social order was hopelessly bad and that the only safety for the individual was to isolate himself in the desert or a monastery.

Monasteries and the Social Conscience.

It is doubtful whether Protestants have sufficiently appreciated the work of the monastery in the medieval society. To the modern aggressive Christian, who believes that the one who follows Christ must lose his life in the world contest in order to find it, the act of the 
monk who secludes himself in the monastery from the social conflict appears that of a craven. Unquestionably there is truth in that charge against the monk of our own time, doubtless there was truth in it even for the time when the monasteries overlooked most of the valleys of Italy, and the deserts of Thebaid could number their hermit cells by the thousand. Yet it is easy to overlook the fact that the monastery played a part of some importance in the development of the social conscience.

The community within the monastery walls was pledged to democracy. Whether the candidate wore the purple, or had the iron ring about his neck, all distinctions fell away as he passed within the walls. Each gave up the name by which he had been known, lest it recall the social distinctions of their former lives. While the noble may have had his servants at his call, within the monastery he must scrub or dig as his lowest menial had done. While this community was only a little section of the world at large, it had no slight significance that even here there was no outward mark to distinguish rank.

The vow of the monk pledged him to poverty, chastity, and obedience. The monk may not have regarded these vows as good for all men, he did not dream that he might win the world to their acceptance; his was the acute conscience which must at least realize these things for itself. So far it was only the development of the conscience of the select few, yet such leaven does not lie passive in the lump. For the time, the idea 
of the equality of all men before God might be limited to the monastery walls, there alone might the idea be realized in conduct; but the time must come when the idea thus nursed into vigorous life would go out to the conquest of the world.

On first sight, the vows of the monastery do not appear democratic. The obligation to obedience, which was rigorously enforced, seems like a subordination of the individual to a superior; but it was obedience to a superior whom the monks themselves had chosen. He was not imposed on them by some outside authority over which they had no control. The superior was one of their own number, who was allowed to exercise a discipline that was scarcely less than military in its character. To this position of superior any one might aspire, regardless of previous birth or wealth, since these worldly distinctions had no meaning under the monastic regime. It was quite possible that the former servant might be placed in authority over his master, the subject over the kilig who had taken the monastic vow.

The vow of chastity, from which certain disastrous results followed, had this democratic tendency in that it prevented a hereditary priesthood. Had it been possible for the abbot to have handed down his office to his son, as was the case in political affairs, it might have resulted in the formation of a priestly aristocracy. This was what had come about in the heathen religions, and would have likewise in the Papal Church. But the office was recruited from the lower ranks of society. 
When the enthusiastic followers of St. Simon a century ago adopted the monastic life, they reproduced many of the characteristics noted here. Under the impulse of the democratic idea, the greatest scientists of France, her authors and her artists, might have been found at Menilmontant doing the work of servants; men such as David, the composer of operas, and DeLesseps, the famous civil engineer. It was of account that rank and honor should not make one look down upon his fellows, even though this idea should be realized only in a limited area.

Now it is pertinent to ask if it had not been better to act this equality in the world, rather than within four walls? Why should they limit their brotherhood to the few individuals who took the vows, to the exclusion of the great mass of men? Doubtless many of the evil consequences of the monastery had been avoided if such a course had been taken; doubtless if the monastery had not been built up at that time when it furnished an outlet for a social impulse, an enthusiasm for humanity, the monastic foundation would not have been with us as anomaly in the social life. But each age has its limitations and it seems better that the democratic idea should be fostered among the few, than to have no place at all.

Every idea has had its period of infancy when it must develop in seclusion in the possession of the few. Not at once does it leap out armed for world conquest. The Mosaic legislation was intended to keep the Jews a separate people until the new conception of God and 
human brotherhood should permeate the social life. When this had been accomplished, when the Jewish people had been bound together in a common purpose, the wall of partition between them and the Gentiles was to be taken away in the death of Jesus Christ and the Jews were to undertake their universal mission of moulding the world after the model which they had been taught. In some slight degree the monastery had the work of training up the idea of equality and brotherhood. The early Church had had this idea finely realized in the community of goods and interests, but the popularizing of the Church increased her numbers at the expense of her character. The monastery came in as a crude attempt to preserve the idea of equality which was in danger of extinction.

It is the great sad fact in the Hebrew history that when the Christ came, the one whom they had been in training for fifteen centuries to herald, they did not know him, and the Hebrews put the Hebrew ideal on the cross. So when it had done all that it could do in promoting the democratic idea among the chosen few, and the time came, as it had come to the Hebrews, of heralding the idea of equality for which it stood to the world, the monastery insisted on keeping the idea in the napkin of the cloister walls: Such opportunities come but once.

Both the Hebrew and the monk mistook the means for the end. The Hebrew insisted on holding by the legal ritual, instead of its unfolding in the gospel; the monk would still remain a hermit when he should have 
become a missionary for the modicum of truth which he preserved. With the awakening of the Renaissance, the time came to abolish the dualism between the monastery and the world, yet the monk refused the work for which he had been trained. Had he thrown away his monkish garb and ritual, and come out to proclaim to the world that there was a common standard for all men; had he taught the common equality of men under God, or under men of their own choice, the history of the Reformation might not have been written in its present form. History is full of the records of nations, and institutions, and individuals, that have failed to fulfill the mission for which they had been called, that even sought to bar the way of its fulfillment.

\section{The Individual and the Social Conscience.}

It is through the intense convictions of the conscience of individuals that the social conscience is instructed and aroused. Spontaneous generation is no more true in psychical than in physical life. When individuals come to have settled convictions on social questions, the issue will be forced home on others. Florence Nightingale had a conviction that the British soldier deserved a treatment which he had not received, and her devotion to that idea brought about a social conviction that ameliorated the condition of the camps. Charles Dickens believed that the Chancery Courts caused many arrests of justice, and the force with which he presented his conviction, roused the social conscience through his influence over the conscience of individuals. The social 
conscience must be reached through the individual conscience. This, however, should not be made an excuse for the failure to instruct men on social questions. Through the enlightenment of the individual mind on social affairs is the social mind enlightened and the social conscience aroused.

The Reformation and the Social Conscience.

The Reformation cane because the existing institutions, political and ecclesiastical, had caused an arrest of democracy, so that only a revolution could free the individual from his limitations. On one side the feudal lords had bound the individual by rules and ground him with taxes till his living was precarious; the kings simply voiced the order of these feudal barons; the Church had denied to the individual the right of private judgment. The Procrustean bed of institutions had become too short for a man to stretch himself in it and must be changed to save the man.

The monastery had stood for a moral dualism, since it did not insist that the man outside was bound by the same law as the man inside. It taught a dual code of conduct. The Puritans of the Reformation insisted that this dualism should cease and that the democracy of the cell become the democracy of the whole social life. The individual, it was held, did not live the good life, who made himseif an abstraction from the world conflict. This means that the individual conscience trained in the monastery must now be socialized and put to work. It denied any geographical morality. 
The monk had taught the vanity of earthly things and the supreme importance of the spiritual, and would deal only with eternal coin; the Reformation conscience held that all individuals and all the affairs of life were of importance to the man. Before this new social conscience the Pope was called to account, and it followed as a necessary corollary, though Luther did not recognize it, that both the king and the feudal lord must render an account of their stewardship before the same court. It is the usual misfortune of the exponents of a new social order that they fail to see the complete application of the truth which they proclaim. Luther demanded liberty of judgment; at the same time he justified slavery. $\mathrm{He}$ insisted upon freedom from papal exactions; he severely condemned the Peasants' revolt. To the one who looks upon these events from the vantage which years furnish, it is clear that these movements are not antagonistic, but only different spheres in which the impulse toward freedom for the individual manifested itself. The contest for the appreciation of the individual in the Church was logically followed by the struggle for political and economic emancipation. If the downmost man is to have his true value allowed in the Church, it could be only a question of time when he would stand before kings and barons, no longer with a petition, but a demand.

The Reformation is the demand of the social conscience that the individual should have room to grow. Previous to this time the energies of Europe had gone into the Crusades for the rescue of an empty tomb; 
now Europe turned to face the West and the future, sent Columbus to find a new world where freedom might take root, invented the movable types for the freeing of thought. The individual had broken his shell of old tradition. The Exighty Years War between Spain and Holland was the attempt of the former, representing a traditional past, to fetter, with the inquisition, the growing independence of the latter; after Spain had spent her sons and her treasures in a futile attempt to restore old conditions, she was obliged to give the Dutch their freedom to think. The social conscience condemned the Spanish methods and all the treasures of the Indies were poured out in the hopeless attempt to reverse this judgment. Armies can not conquer conscience.

Religion was the chief factor in the Reformation conscience; so it is ever. It was Christianity that placed the true value upon the individual and has compelled society, in some measure, to accept the estimate which Jesus put on him. At any period in history when religion has lost its influence, the individual has lost his rights. The social conscience can bring about the realization of the ideal of the free citizen in a developed democracy, only when Christianity permeates the social life. Stifle religion and an aristocracy results. It may be of soldiers, as in the past; it may be of traders, as in the present; but in one way or another it will come. The great aggregation of capital and combination of capitalists known as the liquor power, regards the downmost man as its lawful prey, is careless of individi:al welfare. For the sake of the dimes that may be added to its mighty 
revenue, it crushes the poor in his poverty and disinherits the man of his manhood. In other lines of corporate control, for social control is largely in the hands of the trading corporations, there is like, if not equal, disregard of the "mudsill." Only a Renaissance of Christianity can arouse the social conscience to assume its rightful place as the dominant psychic factor in social affairs.

What is essential in our own times for the development of the social conscience, with its consequent guardianship of the individual, is the enlightenment of the social mind. Not in modern times has the military censorship, instituted rigorously that the home people might not be informed of the methods used abroad, and the industrial censorship which has been enforced against press, pulpit and platform, been more in evidence than in the recent months. The need of the social conscience is complete publicity of social events.

Nor is publicity sufficient of itself. History proves that the logic of circumstances is required to give the logic of argument a value in the social mind. The victim of Claverhouse made no mistake when he said to that brutal inquisitor, "You will make more Whigs in one day than all the hill preachers of Scotland together." "The blood of the martyrs has been the seed of the Church," because it has been a louder call to conscience than the preacher's word. The men who looked upon the sacrifice by fire of Patrick Hamilton saw a new meaning in the truth for which he died.

In the time of the anti-slavery struggle, pulpit, plat- 
form, and press, preached the doctrine of human freedom, appealing to the social intelligence. For a generation the teaching was continued until it seemed to many that the work of education had been completed. But such was not the case. The truth had been told, but it had not won social appreciation. Something was needed to make men see the truth in all its relations, and thus feel an interest in it. Voice and type had done their part, and could do no more, when the appeal was made to the arbitrament of war at Fort Sumter. Nor even yet was the lesson learned, for the men who marched southward from farm and factory did not go to free the slave, but to save the Union. God in His providence led the Federal forces to defeat in Virginia, until the tide of invasion turned and Lee came into Maryland, threatening both Washington and Philadelphia. Then, and not till then, did the social mind understand the sinfulness of human slavery and justify President Lincoln in the emancipation of a race. Nothing short of the agony of war could bring the country to an understanding of the situation. The thought must, in some way, be made of such importance that men will feel and will.

The social mind seems to be going through the same process on the question of the saloon. The social damage inflicted by the saloon and its adjuncts has been so fully and so frequently set forth that there seems little need for further witness.

It seems probable that, as in the case of slavery, the lesson will have to be interpreted by the force of events. A half-century ago it was necessary that the State should 
appreciate the infinite value of the individual even though he wore a black skin; it is necessary now to realize that not all the revenues of the saloon can weigh against a single life which the liquor traffic destroys. The social intelligence must be so developed that it will rate the man at the valuation which Jesus placed upon him.

A century ago the call was issued in Europe and America to safeguard the individual: but it was issued in the name of infidelity. Today when our great political parties have agreed to withdraw privileges which the negro has legally enjoyed for a generation, when England is legislating toward the forcing of the Government religion on the pupils in the schools, when subject peoples are held for commercial exploitation, there is need to issue again the call to safeguard individual freedom in the name of a social conscience enlightened by the teachings of Jesus.

Nash. The Genesis of the Social Conscience; Dewey, The Study of Ethics; Dewey, (Iutlines of Ethics; Mackenzie, Manual of Ethics; Addams, Philanthrobv and Social Progress; DeCoulanges, The Ancient City. 


\section{SOCIAL FORCES}

Mr. LEWES, who accepted the authority of history, though denying that of revelation, once said to Mr. John Stuart Mill that it must be admitted that certain influences for freedom which had not been known before, came into the world about the time when Christ was on the eartl. It was not, however, the initiation of the struggle for freedom, for that had been going on through the past; it was the time when a new impulse was given to the factors which make for the realization of human freedom.

It was to the disciples who felt within them the stirring of a new life that Jesus said: "The Kingdom of God is within you." Henceforth it was to be an unresting contest between the individual and social forces of indifferentism and retrogression on one hand and the progressive Kingdom of God on the other. The Kingdom of God aimed at nothing less than universal empire in the hearts of men; it brooked no rival, would make no terms. At first the inspiration of a few individuals, it so transformed these men that they infected those whom they touched. "It is like leaven which a woman took and hid in the meal," since each changed life became a constructive influence in the lives of other men. The Kingdom Against the World.

The kosmos, or the world, is Paul's designation of the 
life which is not transformed by the spirit of God. Paul contended with this world in the lives of other men; he contended with it in his own. The world was the dominant influence in the lives of the men to whom he preached in the capitals of the Mediterranean neighborhood; it was still an influence in the lives of the Christians whom Paul calls his "little children." Now the Kingdom was to come into the individual and the social life as a new principle, to contest for domination with the world which was in possession.

Between these two psychic forces in the social life, there could be no truce, or compromise; either the world, or the Kingdom, must gain control.

Mr. Herbert Stead has defined the Kingdom as "the fellowship of souls Divine and human, of which the law and the life are love, wherein the Fatherhood of God and the Brotherhood of Man, as both are embodied in Jesus the Christ, are recognized and realized." This comprehensive definition sets before us one of the psychic forces in the social life, of which Jesus Christ is the inspiration. It comes into the life and takes such complete possession that Paul could assert: "It is no longer I that live, but Christ liveth in me." Yet the world still remained as a factor, even with the Apostle to the Gentiles. The kosmos, as it is treated by the apostles, does not refer to a place, but to a principle of life. This kosmos rules in the individual and the social spirit, until the Kingdom enters and wins the contest for the supremacy of the life. Conversion of the life, individual or social, relegates the kosmos to a subordinate position. 


\section{Paul's Statement of the Case.}

In the letter to the Romans, 7 th chapter, Paul gives his experience of the struggle between the Kingdom and the world for the control of his life. He laments that "the good I would I do not; but the evil which I would not, that I do." So far as Paul was concerned, the Kingdom was in control; he willed the good thing, yet the world had such hold that it could vitiate the act. Paul does not claim that he is not free to choose; the lack comes in the performance. "For," he says, "I see a different law in my members, warring against the law of my mind." The kosmos had so permeated his life, that it could not be entirely expelled, even though it could be kept under. In this struggle of an acute conscience we have the psychological factors which work for and against righteousness. Paul is not leading a dual life; he is describing the conflict which goes on within the individual life. The individual is the battle field as well as the contending forces. One or other of these forces is always dominant and that one is decisive of the character of the life. Not that either becomes so completely dominant as to be uninfluenced by the other. It is doubtful if any man ever becomes so bad as to have no good impulses, or so good as to be entirely free from the evil principle of the "world." There is always some opposition, however slight, whether there is moral development or declension.

What Paul so vividly experienced and described in his own life, finds its counterpart in the social life. There also the world is dominant; there too the Kingdom enters 
the field and struggles for the mastery. Since the world has control in the major number of individual lives, it has control in the social life, yet is this mastery not so complete as to entirely eliminate the psychic principle of the Kingdom. Paul brings out the fact that the evil principle was able to leave its taint on every act. The disease which shows in the hand, indicates the impurity of the life current in all parts of the body; so does sin prevent the act from satisfying all the demands of the situation. While society today is not Christian as Jesus Christ defines Christianity, yet it is not what it would be if the Kingdom were eliminated as a social force.

For the purpose of our study of society, both the Kingdom and the world are present, active factors. Each is trying to monopolize the field and make society entirely in its own pattern. Each of them expresses the belief of certain classes in society and they are arrayed against each other on every great social question. It is impossible to identify these psychic forces with particular institutions. The Church has for its work the bringing in of the Kingdom, but it is possible to find some outside the Church that are as closely identified with the social force that makes for righteousness as some that are within. The line between the opposing social factors can be drawn with greater accuracy by principles, than by institutions. The principle of action in the Kingdom is love; the principle of the opposition could scarcely be better defined than by the word force.

According to one or other of these principles, each 
individual must line up his action; not that either principle will cover each particular thing that he may do, but that one principle will have the dominant place. He adopts one or other as his ethical standard. Between the dominions of these principles there is no neutral ground; for as Jesus stated the case, " $\mathrm{He}$ that is not for us is against us."

In any movement, psychical or physical, the inert element must be reckoned with; so in the social movement it has its influence. If society is moving toward a higher moral level, the force of inertia, of that whole class of indifferent individuals who think themselves neutral, must be overcome before any progress can be made. The Apostle John looks on this class of men as specially objectionable and writes of them: "I would they were cold or hot." Whatever advancement is secured must be by overcoming the opposition and also lifting the dead weight of the people who, "did not care which." The neutral man is found to be a dead weight on the wrong side of every reform.

It is upon the indifferent class, upon those in what we may call a subconscious moral condition, that the reformer does his work. His antagonist he may not expect to win to his position, but if he is able to force the issue upon such as have not yet declared themselves, he may recruit the ranks of those who make love the principle of social action. Elijah as he confronts a people wavering between God and Baal forces the issue by his demand: "Choose ye this day whom ye will serve." It is to gain this end of forcing men to take sides that 
the champion of the Prohibition cause strives to bring on a collision between the Church and the saloon. $\mathrm{He}$ believes that if men can be forced into a choice of sides, the victory will be won. The citizen has not the right to be indifferent to any question which concerns the social welfare.

The individual and the social spirit furnish the field for the battle of the standards. The principle of love, which is the principle of the Kingdom, is embodied in Jesus Christ; the principle of force which is the ethical standard of the world may be found scientifically stated by Weismann. By this statement it is not meant to assert that any great number of people accept the extreme Darwinism taught by Weismann, with any idea of endorsing that author or his views; what is asserted is that the ethical standard which dominates social action is the application of the doctrine which goes by the name of Weismann. Many of those who fall under this classification may never have heard of Weismann, might even deny the validity of evolution; but nevertheless they might find a fair scientific basis for their ethical theory in Weismann's writings.

Darwin had made natural selection the center of his system, but he added to it use-inheritance and sexual selection to aid in the explanation of progress. Weismann discarded the two last factors as having no place in his scheme of evolution, so that it will be necessary in explaining the position of Weismann to deal only with natural selection. It is not necessary to the purpose here to enter into a discussion of Weismann's " germ 
plasm" which is passed on unchanged from parent to child through the generations; nor is it necessary to deal with "amphimixis," the chance combination of the paternal and maternal packets of "germ plasm" which allows for variation. The interest here lies in its ethical application, so that we are only concerned with natural selection as an ethical standard.

Since natural selection, according to Weismann, is the only factor in progress, struggle is the essential element. Nature is prodigal in the production of life and competition is the method by which the unfit are weeded out, while the strong possess the land. Mr. Kidd builds his book on "Social Evolution" on this foundation, following Weismann closely for the most part, so that one will gain a fair understanding of what the doctrine of natural selection means when put to the service of ethics by reading Mr. Kidd's discussion. Mr. Kidd and Weismann agree that any limitation on the struggle between individual organisms would stop the progressive movement and would mean social stagnation to the society in which it occurs. It is true, they would admit, that we may go down in the fight for life; but we must die if we do not fight. Only in this way may the vitality of society be preserved and new conditions created. We must fight or die, or fight and die. Struggle is the first necessity in life.

It is through this relentless struggle where each must fight for his own hand that the fittest is picked out and the "survival of the fittest" is assured. The vanquished failed because he deserved to fail, therefore it is the 
necessary conclusion that the winner always has the righteous cause and to him be the glory. The winner is to be commended because he won; the loser condemned because he lost. The conclusion is not simply that might makes right, but that might is right. To interfere in the struggle between two individuals, or two nations, in such a way as to influence the result, might bring about the survival of the unfit; it is only when the victor spoils the slain that we are certain which is right in the quarrel.

Now while this struggle for life is going on among the individuals of the race, it is the environment which chooses that type of individual, brute or human, which suits the conditions existing at the time and place. That is what is meant by natural selection. In the biological field, the environment is material nature, therefore thought and purpose have nothing to do with selection. Both Weismann and Darwin agree that the variation in the individual which enables him to survive, has not been foreseen, coming in casually. Variations are all in random directions and it is the environment which rejects the multitude of the unfit and selects the one which is best. We may get the situation before our mind by conceiving that all the roads which lead onward appear equally good, yet all but one are blind alleys lacking outlets; the individual whose random step takes him in the road which is open, survives, the others perish. Darwin claimed that natural selection had no place for teleology, no evidence of purpose was in the process. There was no place for phophecy since none knew what 
variation might come in the individual, none knew which might be selected by the environment; all must draw at random and most of the cards were blanks.

Mr. Spencer taught that beyond the struggle which was present, lay an age when struggle would cease and a static condition ensue in which egoism is to balance altruism in his ideal society; but Weismann insists that when struggle ceases, retrogression sets in. There is no stage between evolution and dissolution, at which the race may pause. At this point where struggle has been eliminated Weismann puts his stage which he calls panmixia, where the hostile social elements have coalesced through marriage, or otherwise, so that competition is unable to work. This is the beginning of social death, says Weismann.

With this statement of Weismann's biological views, their application to ethics is not difficult. He would argue that our present moral attainments have been reached by the struggle to the death between individuals, between institutions, between ideals. Each man must fight for himself since if he seeks to aid the weak that are being crushed, it will imperil his own success; also it will aid in the preservation of the unfit. We have no cause to extend our sympathy to a weaker people in its contest with its stronger enemy, since the very fact of weakness is an evidence that it should be eliminated. If any course wins in life it is a proof of its rightness since in natural selection it is the environment that selects, a premise which makes the end justify the means. The God of things-as-they-are is the one we should worship. 
This is what we may call the doctrine of natural selection as applied to ethics, or the creed of Weismannism and it is taken here as the social force with which the teachings and the principles of Jesus find themselves in conflict. It is for this reason that some space has been given to its statement and more allowed to its discussion. If existence determines rightness, if worth is measured by survival, then the Kingdom of God is not an ideal; indeed, there is no place for an ideal. Changes are casual, rather than the working out of a conscious purpose. Starting from a premise such as this, it is easy to see why the scientist looks upon the teachings of Jesus as inapplicable at the present time and upon the Kingdom of God as the fabric of a vision. Professor Small recently said to his class: "It is possible that in some future time men shall obey teachings such as Jesus gave, but the guide for present action is the common consensus of practical judgments of humanity." The present demand is to adapt oneself to the environment in which he finds himself. Conformity to the social environment becomes the sole duty of each. The martyr is a sinner against his time. He suffers greatly because he failed to adapt himself to his selecting environment. Does this not express the dominant ethical theory of our own time? Mr. Kipling and his compeers preach it as a sacred duty of the ruling nations to compel the peoples that are less advanced in industrial improvements, to conform to the type of the winning race. It is their business to eliminate the weak and preserve the strong. Is it not the spoken, or unspoken, word of the great 
majority that things are well as they are? Is not our trade balance good, our market firm, our business flourishing? It is exceedingly difficult to convince a popular audience that there is any great moral turpitude in a method of business which results in material prosperity. This conclusion is not consciously based on natural selection applied in the ethical sphere, but it appears to be a fact nevertheless that the theory of natural selection comes in to uphold a certain system of ethics.

\section{Does the Doctrine of Weismann Hold in Biology?}

Professor Poulton in explaining natural selection, takes the case of the caterpillar, some species of which have been found with something resembling a thorn upon their back. Others of the family have been noticed which erect themselves in such a way that they closely resemble a shoot upon the tree. Now it is clear that because of this likeness to the branch on which they are, they will be to a good degree immune from the attacks of birds and other enemies. They can not be distinguished at a little distance from the branch on which they feed. The ordinary form of caterpillar, being more easily seen, will be eaten, while these variations from the ordinary type will survive. How did this variation come about which enables this particular caterpillar to survive while the more common forms perish? Evidently the caterpillar did not study out the situation and conclude that if it could stand on its head it would be like a shoot on the branch; and it is equally evident that the other type did not plan the thorn upon its back. The Darwinian 
would tell us that it is simply a casual variation which happened to suit the environment.

It is not hard to see that when the caterpillar does resemble a thorn upon the branch that in the struggle for life among the various creatures which prey on this species, this caterpillar has a decided advantage. It will have a better opportunity to live and rear a progeny with like growths, so that a new kind of caterpillar is in the field.

But is it final to say that it came about by cnance? If the coincidence which brought about this particular form is simply mechanical, if there is no design in the case, perhaps such a conclusion may be accepted. But there is another authority on the subject of heredity which says that all things "brought forth after their kind"; and it may be quite as scientific to make the claim that the variation mentioned was simply the unfolding of the characteristics in the life germ, as that it was "casual." It is a commonplace that the acorn contains the future oak, or even the future oaks, so that the divergence in oak trees need not be laid to random variations.

But this is looking at the matter of variation only from one standpoint. Science considers the subject from the standpoint of the part; philosophy from that of the whole. It would seem unquestionable that the conclusions of science should agree with philosophy; also that the philosophic conclusions should be verifiable by science. Now it is agreed by modern philosophers that the universe is in some sense organic, and the conditions of an organism 
demand a vital relationship between part and part, also between the parts and the whole. It demands that each part shall perform its proper function in the organism and contribute to the interests of the whole. How then can the idea of "struggle" between the parts be the fundamental principle of development? How could one assert it as scientific truth that the changes which come about are only random variations? It is not proposed here to deny that natural selection is a factor in the development of the lower forms of life, but to deny that it is the dominant partner in the process. Natural selection may eliminate the unfit, it may have some part in strengthening the fit, but it fails to explain how the fitness arises.

Another thing to be considered is that if life is organic, including its various forms, it can not mean a struggle each for itself. How far Drummond remedies the defect in natural selection by his bringing in of struggle for the life of others, need not be considered here. Yet it does not appear that even Drummond looked at the case from the standpoint of the whole. Paul brings out this organic relationship in the higher life when he writes " none of us liveth to himself, and no man dieth to himself." If this rule is applicable to the lower life as well, and Mr. Herbert Spencer claims that it is, then co-operation rather than struggle is the rule.

Mr. Spencer has attempted a cosmic philosophy, which assumes to bind the universe together under the operation of certain laws. From this premise he argues the inadequacy of natural selection as the cause of progress. To 
make the matter clear we might consider a pioneer village in the coloniai days. In its beginning each settler would be a farmer in some measure, since food had to be gotten from the soil and there would be little division of labor. Gradually the community becomes more complex in its interests and each household becomes more dependent on the labor of others. No longer do all till the ground, but we find one man building houses, another making shoes, another weaving cloth. The community is growing from the simple to the complex, through division of labor. Shall we say that we find in that village life an illustration of natural selection through struggle; or is it not rather a growth through co-operation? Weismann and Darwin would have to defend the former proposition and Mr. Spencer the latter.

Evidently when the scientific doctors differ, one need not be discredited scientifically because he exercises the same privilege.

The purpose of this chapter is to show that the biological doctrine of natural selection, whether it is called Darwinism, or more exactly Weismannism, should not be applied to the settlement of moral questions as is being done; and as it is open to serious question whether natural selection may claim dominion in its proper sphere of biology, we may with greater assurance deny its claim to rule in ethics.

\section{Environment Selects.}

There is one further point to be noted before leaving the biological phase of the subject. The environment 
makes the selection. In the case of the caterpillar its environment would be, for the most part, the tree on which it fed, the quality of air, and the animals which sought its life. It will survive as it is able to meet all these conditions. The animal has nothing to do with selecting itself; its life or death is determined solely by environment. Hundreds fall in the struggle as they prove unfit and only the few meet the test. It does not seem that there would be much use of Jesus Christ coming to die that he might redeem a world built on that plan.

The Application of Natural Selection to Ethics.

The question now to be studied is whether the rule of the woods and the fields, if it is not discredited even there, may be properly taken as the ethical guide in human affairs. According to this conception there is no merit in feeding the hungry and clothing the naked. Rather is that class of actions the perpetuation of weaklings whose very need shows their unfitness to survive. The difference of opinion which one individual has with another is but casual. There is no absolute standard of right and wrong, since this is determined only by what the environment demands. If one is in Rome he meets the conditions of life by doing what the Romans do. To set up a standard of life which is contrary to the prevailing belief and practice, to try to live his life by such standard, is not an evidence of goodness. Rather does it evidence an unfitness to survive. As the environment is the final judge of righteousness and unrighteousness, 
one belief may be as good as another until it has been tested by public opinion. If the crowd rejects it, it is not good. There is no justification for the one man, or the few men, standing against the crowd. It is not a question of what the moral law demands, it is not a question of what the teachings of Jesus demand, it is only to consider what are the demands of environment.

\section{Is Natural Selection in Ethics the Popular View?}

According to the view taken in this chapter, the question should be answered affirmatively. Not that there is not continual and effectual agitation for the relief of the defective classes, not that "struggle" is not checked at many points; but that the general teaching of the press and the public administration, is based upon the ideas which belong to the doctrine of natural selection. It is to be gladly affirmed that war plays a decreasing part in the history of the race; though it is yet true that the burden of armaments in preparation for war, weighs heavily on the civilized world. It is no small gain that private war has been so generally suppressed, and internal affairs of State adjusted in so many cases by reason rather than by force.

But it is questionable if the method of suppressing the weaker portions of humanity, has not changed its method rather than its principle. We have ceased to cut throats in the old brotherly fashion, yet the cutting of prices looks frequently to the same end. The strong individual breaks down his opponent by mental superiority in the particular field and not by superior muscle, yet 
when one takes into account the material addition which immense capital gives to the man that wields it, the difference between the old and the new conditions is not so great. Civilization has veneered the ancient villain of the game of war.

The Industrial Situation.

If the doctrine of Weismann is to have a dominant place in business, it means that sentiment must be eliminated from the methods that are used. It means that competition of each against all, shall go on unchecked by any feeling of sympathy that would affect the making of a contract. President Walker, in his work on Political Economy, has defined competition in the terms of natural selection. "Whenever any economic agent does or forbears anything under the influence of any sentiment other than the desire of doing the least and taking the most he can in exchange, be that patriotism, or gratitude, or charity, or vanity leading him to do any otherwise than as self interest would prompt, in that case also, the rule of competition is departed from." As President Walker argues for competition as the principle of business activity he may fairly be taken as an exponent of Weismannism in industry.

Now if this conception of competition was actually realized in the factory and the market, natural selection would have the field to itself and just so far as the principle of "the longest tooth and the sharpest claw" has its way, this is the case. Such a conclusion would bar morals out of business transactions and leave the same principle for the market as the battlefield. 
How far is it realized? It is probably an exaggerated statement, though it is current, that ninety per cent. of the business men fail at some period in life. However this may be the percentage of such failures is very large. In many cases the failure finds its sufficient explanation in incompetence, yet it appears to be true that the majority are crushed by combinations of capital, a result which no amount of sagacity could have prevented. It is in many cases a trial of strength in which the one who can command the most capital is able to crush his rivals in the race, and he looks upon it as a mere matter of business to do so. He plans his campaign and carries it through as does a general when he forces his enemy from one point to another in his retreat before a superior force.

It has been said that the purpose on the battlefield is to exterminate, while in business it is only to conquer, but this is scarcely a complete statement of the case. If a soldier is killed on the field, he can be left to lie where he falls till there is leisure to scoop for him his shallow grave, while his comrades close up the ranks and march on; but each wounded man takes three from the ranks, since two must aid their wounded comrade to the rear. In business, men do not seek to kill, but to disable. Of the two thousand empty store rooms in the city of Chicago some years ago, many of the former proprietors found their places behind the counters of the department stores which had crushed their little ventures.

Very few are the railroads of today that are held by the men who sunk their fortunes in them at the first; 
for the reorganizations through which the railroad companies have passed, have reared the present business on the ruins of the former companies, which proved themselves unfit. Then when the business has been wrecked, society is left to care for the wounded, and also to pay the expenses of the war in increased prices to the survivor.

We have our organizations of working men on one side, and of capitalists upon the other, standing for different things, yet both parties follow the rules of war, and do not hesitate to plant the blow where it will draw most blood. The union orders a strike when the employer has the most orders in hand, that he may be forced to make the required concession; while the employer takes the opportunity to reduce wages when the artisan can not resist. The battle usually goes in the favor of the employer, because capital can afford to wait with the possibility of recovering lost ground by the higher prices of a reduced stock. But the grip of hunger will not allow the laborer to wait, so that he must accept the terms offered. Now it is not claimed that this correctly states the attitude of all employers, or of all employees; what is sought in this case is the general principle on which industrial operations are based.

Another fact which points to the same conclusion is the eagerness with which the commercial countries are grasping after undeveloped territory which may promise a market for their excess of goods. No question of treaty stipulations, or of human rights, is allowed to tip the balance toward justice, where conquest may 
open a new field for commercial exploitation. Why are the commercial countries not able to find consumers within their own limits for the goods which they produce, that they must seize colonial possessions at such a cost of blood and treasure? Clearly not because the people at home have all the economic goods that they might profitably use. The most plausible answer is that the relentless competition has taken from the masses the power to purchase, though not the wish to consume. So we see the Governments, in order to extend their commerce, burdening their people with heavy war debts which diminish yet more their power to purchase what the market affords.

This fatal policy which shortens the actual market at home, to win a possible market abroad, seems to show that the accepted industrial principle must be at fault, since it thus works disaster to the people, as well as to the industrial interests involved. The suggestion may be worth making that the acceptance of the ethics of Jesus in the conduct of our great enterprises, might make it annecessary to seek out some less developed people, where the market must be opened and kept open with the bayonet. The application of the ethics of natural selection within the national group leads to its application between the nations.

\section{The Political Situation.}

It seems to admit of proof that the ethics of the "struggle for life" is dominant at the present day in industry; we may now consider whether the same con- 
clusion may be drawn in regard to political action. This conclusion may be reached by a study of the principles upon which political action is based, and by considering the practice under those principles.

We shall get at the principles on which our political structure rests, by referring to the written constitution of government which went into operation in 1789 . Upon those principles the government was erected and has been administered during the century which has elapsed, seeming to suit the people as well now as when adopted. Every one who has shared in governmental action since its adoption has done so upon the basis of this fundamental law, and so long as the present law is in force, there is no other legal basis. It is therefore proper to refer to the Constitution of the United States as containing the principles upon which politics rest.

The Constitution, in turn, rests upon its preamble, or enacting clause, which reads: "We the people . . . do ordain and establish this Constitution for the United States of America." This legal enactment expressly states that the source of political authority is in the people; and while this means the organic people, rather than any number of individuals, it remains true that the will of the organism must find its expression through the majority. According to any democratic conception of the State it could not, and should not, be otherwise. But if the ultimate power is lodged with the majority, if the majority is the source of law and right, do we not have the doctrine of natural selection where the variant individual or minority must depend for the right to exist 
upon the environment, the majority? It is quite true tnat the minority is itself a part of the environment, yet it is so far a subordinate part that it can not regulate it. Comte argued, and his point is made frequently in these days, that since the individual is a member of the organism, that he should submit to it. But suppose the majority is wrong, must the individual accept their conclusion and act upon it? By this method, must not right and wrong be decided by a count of heads? Comte taught that humanity is the God of the individual. Humanity is the end of his service, the object of his worship. Taking such a premise as the basis of reasoning, it is clear that if the individual should set his opinion, or his act, against the crowd, he would be guilty of impiety. Is not that the idea which underlies much of the social teaching of the day? Not that the extreme position taken by Comte is accepted in words, but there is a suggestive likeness in the conclusions drawn. Not infrequently is it asserted in the press and elsewhere that when the country has fairly decided on a course of action, it is the duty of the loyal citizen to accept that decision and act upon it. A citizen may object to war, but once it is declared, he is under obligation to support the war, however unjust the cause may appear. Such statements have been current coin in the party papers of England and United States during the recent wars. The venders of such sentiment might touch elbows with Auguste Comte. It can mean nothing short of this, that the individual should submit his conviction to the decision of the social environment, the mass of the people. 
It may be that these are not the expressions of the social mind, but their currency would suggest such a conclusion. The teaching runs that when the individual has expressed his belief he should then be ready to act with the crowd against his belief. This means nothing less than the application of the ethics of natural selection in the discussion and settlement of the questions of the day. The man, or the opinion, which the environment chooses, is the fittest to survive.

Now if the will of the people is ultimate, must one not conclude that when the people have decided on any course, the citizen is in duty bound to subscribe to it by act, if not in thought? If there is a higher will than that of the people to which the popular will is subordinate, then the judgment of the social will may be questioned, but not otherwise.

Nor does it appear that the practice of politics differs radically from the principles on which it is based. Our method of treatment of the Indian during "a century of dishonor" shows that he is looked upon as "unfit" and his elimination is proceeding with more or less rapidity. One hears less frequently the saying that "the only good Indian is a dead Indian," but the practice has not suffered radical change. Treaties which secure to him his land are seldom binding when his holding becomes valuable.

Specially does this idea show itself in politics when voters are urged to give their support to some new proposition, such as the prohibition of the liquor traffic. At once is the question broached as to whether the project 
can receive a majority of votes, and if this does not appear probable the measure is chosen which is likely to have the popular support, even if the individuals themselves are not in sympathy with it. There is a dread of voting with the minority which has considerable effect in deciding how ballots shall be cast. Who has not met with the idea of being "odd," as a controlling influence in the choice of actions?

Perhaps the individual is not in any danger from the crowd, yet it is fair to say that where "the will of the people," is the final arbiter of individual rights, freedom is on a precarious footing. The Constitution guarantees the right of jury trial, but the liberal use of the injunction shows how this may be set aside in many cases. It may be that the judge of the Equity Court will guard individual rights as surely as would the jury, yet it means; to a large extent, the suppression of jury trial in any quarrel between employers and laborers. Paper guarantees are a poor defense when there is a popular demand that they be set aside. All these instances which might be multiplied, suggest the conclusion that "conformity to environment" is the dominant ethical idea in our social life. How frequently is the epithet of traitor applied to the man who proposes to criticise political policies supported by the majority? Continually is the effort made to suppress discussion on any question where the popular will has been expressed.

Now it is frankly admitted that the conclusion drawn, which makes natural selection the ethical creed of the "world" of this age, may not be the correct one; nor 
is it beyond question that the "world" furnishes the popular creed; yet the statement is ventured that when any other conclusion is taken it will be open to graver objections than the one offered here.

\section{Dualism in Ethics.}

While holding the beliet that there can not be any reconciliation between these conflicting ethical ideas, it is only fair to state that Professor Giddings has made a proposal of that kind in his work on "Democracy and Empire." Professor Giddings deals with the idea of natural selection, making Nietsche its exponent, and holding with Nietsche and Weismann that to eliminate the "struggle for life" would take away the incentive for human effort. This would result in "panmixia" and the consequent degeneration of the people concerned. Professor Giddings holds that both social ideals, that of natural selection and the teachings of Jesus, are necessary to the social welfare. He allows that struggle may be eliminated from the group as the law of its life, but that it must be kept in working order somewhere to prevent stagnation. He would admit that we may reach the time when competition of the natural selection type would be excluded from the family and the neighborhood and even from the State. Within these limits we may follow the teachings of Jesus and become bearers of each other's burdens without incurring the disastrous results which Weismann feared from "panmixia." In fact Professor Giddings would teach that such an extension of the ethics of Jesus might be of great advantage to the society. 
Up to this point Weismann has been discarded, but for the remainder of the way the paths of Weismann and Giddings lie together. Internecine strife may be abolished, but the vitality of the social life must be preserved by struggle between the nations. Thus Professor Giddings proposes to divide the earth between these two forces, allowing the teachings of Jesus to have free course within the State, but giving Weismann his way in international affairs. It must be admitted, so far as international affairs are concerned, that this ideal comes close to the actual. Whatever may be said as to the ethical code within the group there is no international code of ethics except force. However, neither the teachings of Jesus, nor modern philosophy, makes provision for such dualism in law as that proposed by Professor Giddings. There is no suggestion from either source of a division of territory between conflicting laws. One does not find anywhere in the teachings of the Christ a proposal that he would admit of division of the world with Weismann, or his kind. From the old days of blood and iron, when each family, and tribe, and people, was an Ishmael to all outside its limits, have come down to us ideas which we are now asked to accept because of the trade-mark of science upon them, as if baptizing them with a new name might change their character. It is a pitiful doctrine that the strong can keep his strength only by shedding the blood of the weak.

The Comparison of the Social Ideals.

It is spirit against matter; love against force; experi- 
ence against faith. Weismann would say that each must struggle for his own hand; Jesus said "love your enemies." The former argues that strength comes through resistance; the latter that it comes through sacrifice. Where such antagonism exists there can be no compromise. Jesus Christ claims the social life as his own, and means that the Kingdom shall come in it so completely that there will be a social incarnation. Struggle there is in abundance since the great apostle to the Gentiles draws his illustrations from the arena and the race course and proclaims his triumph in the words: "I have fought the good fight." Yet this is infinitely removed from the doctrine of struggle incident to natural selection. Jesus stated his method of survival when he said: "He that would be greatest among you, let him be servant of all."

It is in the Christian's confession of faith that the teachings of the Christ are practical in method and universal in application. They are suited to the needs of the social life and no less to the intercourse between States. When we see each country piling its frontiers with fortresses and massing its sons behind stone walls, through dread of a neighbor who is wasting, in the same costly occupation, an amount of social wealth which would lift the poor of the land from poverty, it needs no further argument than the statement of the facts to show what a priceless boon it would be to the nations to gain the ethics of Jesus as the rule of life. While the representatives of the different countries profess friendship for each other, the fact occasionally comes to light, that 
at the same time spies are being maintained at the rival courts. So long as the ethics of Weismann dominate in political affairs, must the peoples waste their spiritual and material treasures in the worship of the strange god of force.

Yet Ormuzd will not forever strive with Ahriman, Jesus with Weismann, though the end be far in the future. For a time must the Christian citizen accept the standing order: "Be not conformed to this world; but be ye transformed." The refusal to conform to environment has had its army of martyrs to whom is due the progress of the race, for the ethics of Weismann are as old as human selfishness. In the advancement of the kingdom there must always be those who "have come out of great tribulation," through their insistence upon the right of private judgment and the duty of projecting the Kingdom into the world.

So far, environment has been considered as the scientist sees it, who looks upon natural selection as the ethical standard. But when our view is enlarged so that the fact of God, which Weismann had ignored, is brought into our plan, the character of environment undergoes a change. What by the scientist of Weismann's belief had been made the whole of environment is now seen to be only a part, even a subordinate part. Conformity to environment in this sense, which to the Christian is its only meaning, is conformity to God. The criticism upon the scientist is that he has dealt with a subordinate part of the field as if it were the whole, and has drawn conclusions from insufficient data. 
The argument of this chapter may be briefly stated. Since and before God became incarnate in Jesus, there has been radical antagonism between what Paul calls "the world" and the Kingdom which the Christ came to further ; so far in the history of the race "the world" has been the dominant social force, though doubtless modified at every point by the ethics of Jesus. At the present time the popular standard of ethics appears to be that of natural selection as proposed by Weismann, which is in direct and irreconcileable opposition to the teachings of Jesus. The conformity to the ideas of the crowd, which natural selection would demand, stands in the way of social progress, which is found only in the progress of the Kingdom. The question is raised whether natural selection deserved the place which has been assigned to it in biology, and its application in the field of morals is altogether denied. The suggestion is also made that the scientist in failing to take the fact of God into account in treating environment, has left a fatal weakness in any conclusions which he may draw from his partial view of the situation.

From Comte to Benjamin Kidd, Mackintosh; Weismannism, Romanes; Social Evolution, Kidd; The Romanes Lecture for 1893. Huxley; Inadequacy of Natural Selection, Herbert Spencer; Darwinism in Politics, Ritchie; Democracy and Empire, Giddings (pp.340-57). 


\section{THE SOVEREIGNTY OF THE STA'TE}

SoverEIgnty is an attribute of will and is not found except in will. If the State did not have mind, there could not be sovereignty in the State. This is the conclusion to which Mr. Herbert Spencer comes when he argues that the State is like the animal organism, having physical powers but lacking intelligence. If, as he claims, there is no psychic factor, if the State is controlled by physical laws alone, then has the State no more of sovereignty, no more of character, than the animal to which Mr. Spencer likens it. It is only a great mechanism which has no power to direct its course.

\section{Sovereignty Includes Choice.}

If one accepts the views of Mr. T. H. Green, the long debate which has gone on over the freedom of the will is without justification. Mr. Green says that the expression freedom of the will is tautological since it is equivalent to saying the freedom of the free thing. It is in the very nature of will to be free. We may arrest a person and shut him in a cell, we may even take his life, but his will is beyond our reach. He makes what choice he will in spite of sheriff and executioner. This characteristic is in each personality which has will. The State has this power of choice and can not be restrained 
in the use of it. When Elijah was on Carmel he demanded of the assembled court and commons of Israel: "Choose ye this day whom ye will serve." They had the power to make the choice and would be held responsible for the use which they made of this power.

In Israel at that time there were two forces struggling for dominance, the one idolatrous, the other holding for the true God. These two elements must both be taken into account in making up the national mind, but when the mind is made up and the choice is made, it is made without restraint. Neither Elijah, nor any one else, can compel a choice against their will. Often in the State there are conflicting elements, but when the social mind is made up, all these things are taken into account. It is under these conditions that the choice is made and responsibility assumed.

Sovereignty Includes the Power to Control the Means for Reaching the End Chosen.

It is at this point that we must distinguish between wills which are sovereign and those that are subordinate. Paul could say "to will is present with me, but to do that which is good is not." The limitation did not lie in his power of choice, but in his ability to execute. The same limitation exists in the case of the State. Bluntschli says, "absolute independence does not exist anywhere on earth." Humanly speaking the limitations of State sovereignty take two forms, the internal, and the external; the former, through the opposition of its own citizens, the latter through the opposition of other States. 


\section{The Internal Phase of Limitation.}

While the will of the State has been made known, it is frequently true that there is an opposition party, indeed it is of much account that such opposition should exist to furnish the needed criticism on the party in power. The idea is more common than one could wish, in the United States at least, that when the State has expressed its will, the minority should accept the result as final in the case. Such reasoning fails to do justice to the protesting minority, which is needed as an incentive to the party in power to take a higher moral standard of action. We need our reformers and they are always in the minority. We need our martyrs who resist unto the death the will of the State which enjoins injustice.

This opposition by the individual should not be based on the plea that he is himself sovereign, or a fraction of sovereignty. The statement that each individual is a sovereign may be allowed to pass as rhetoric, but nothing more. $\mathrm{He}$ is an individual with responsibilities to his manhood, to society, and to God, responsibilities which can be met only by faithful witnessing for the truth as he knows it. While opposition to the carrying out of the social will is not sufficient to change the purpose, it is able frequently to modify the methods used. This is illustrated in the temperance agitation, where the voicing of opposition to the prevailing policy has forced concessions from the liquor power at a number of points. Dominant parties are usually susceptible to criticism. To criticise is the function of the minority. 
External limitations of State Sovereignty.

In the family of nations, of which each State is a member, there is legally a perfect equality. Differences in population, and in wealth, give no pre-eminence in privilege. In a number of cases there is a union among the great States of the world to guarantee the territory of one whose weakness might be an undue temptation to a stronger neighbor. This is illustrated in the case of Switzerland which is neutral ground. What is specially lacking in international affairs is such development of the consciousness of kind, that the aggressions of the larger upon the weaker peoples would be prevented in each case by a union of the other powers. So long, however, as the present rapacity for territory continues, such a condition must remain a prophecy.

Yet even under existing conditions, each State is under bonds to keep the peace in many respects. In many cases, the State may not treat its own subjects as it will without regard to the judgment of other States. America interfered between Spain and her Cuban subjects, though later the hollowness of this act was shown by the adoption of Spanish methods in the Philippines. All the reason why the United States is not called to account is because the other States also have the hunger for territory which they wish to gratify in like fashion. Yet while the public sentiment, which one may hope is gathering against all aggression of the strong upon the weak, has no international institution through which it may have organized and effective expression, the 
various States are exceedingly anxious to place their case before the jury of humanity in such a way as to win a favorable verdict. State action is limited less by what other States have done than by what they might and would do under sufficient provocation.

The Hague Peace Conference was a move in the right direction, but its constitution was defective in that its conclusions were not binding even upon the States there represented. Many of its provisions were disregarded by the powers represented before the report of the conference had been made public. When the stronger powers shall be willing to forego conquests by force of arms, we may gain an international tribunal which will limit the sovereignty of the States by the impartial judgment of their peers in the family of nations.

Sovereignty Rests on Right.

This does not contradict the proposition that sovereignty over a people is often initiated by force. The thought is that force can not be made the permanent basis on which sovereignty rests. States have been defrauded of their birthright with scarcely the grace of a contract for a mess of pottage, but the possession may be kept only by a return to justice. Rousseau said: "The strongest is not strong enough to be always master, unless he transforms his strength into right, and obedience into duty." Physical force is an element in sovereignty without which the State could not preserve itself and perform its functions. But the real strength of the State will be indicated by the infrequency with which it must appeal to the arbitrament of force. 
The strongest State is not the one which must depend upon the dread of its standing army to win obedience to its laws, but rather does strength consist in the possibility of dispensing with such physical aids through the loyalty of a contented people. A large standing army not only saps the industrial and moral energy of a people, but it is a standing notice of internal, or external, weakness. Not only is it a source of national weakness when unwilling populations are compelled to a reluctant submission, but it reacts disastrously upon the social life of the dominant partner. Only social damage can result when one section of a people becomes the taskmaster of another. Sovereignty must come to rest upon justice, else insurrection and revolution become the only relief for an oppressed people. Force may rule till right is ready, provided that justice is not too slow in coming to its own.

Sovereignty and Revolution.

The right of insurrection, though it is admitted only as a last resort, is recognized as the protection against an arbitrary will, whether of the monarch, or the State. In the earlier times, when the ruler could call out his mailed men on horseback to ride down the hundreds of defenseless peasants, this had less meaning than at the present, when the farmer on his croft, with smokeless powder and long-range rifle, is more than a match for the sergeant with his squad of men. Inventions such as those of recent date are putting into the hands of the few, when the cause is worth the risking of their lives, a power which the State will not hastily provoke. The time is 
coming, if not already here, when men must be governed by reason and not by the reckless assertion of an arbitrary will.

Those who have accepted the explanations here given will be prepared to differ with the definition given by Bodin, and recently repeated by Professor Burgess, that sovereignty is "absolute, unlimited power." We have seen that the will, whether of the individual or the State, is not limited in the matter of choice, but is limited in the carrying out of that choice.

Sovereignty is Indivisible.

This is admitted as soon as it is made clear that sovereignty is an attribute of will. The State can have but one mind, but one will, therefore the old claim that sovereignty could be divided has not a leg on which to stand. Sovereignty can not be divided any more than will, and this is clearly impossible.

It is doubtless true that the settling of a question in philosophy does not necessarily end it as a question in political affairs, yet it is more than probable that a correct conception of the philosophy of the State might have prevented the long contest, which ended with the Civil War, over the question of the division of sovereignty.

The South held stoutly for the idea that the respective Commonwealths were sovereign; indeed, there was scarcely a section of the country which did not make the same claim, as the occasion demanded. The view held by the North during the period before the Civil War was probably voiced by Webster, who explained that sovereignty lay partly with the Union, partly with the Con- 
monwealths." So far as argument could be made from the State documents and official statements, the South was able to hold its own, since the Commonwealth Constitutions and the Articles of Confederation, as well as various other authorities, sustained the idea of the sovereignty of the respective Commonwealths.

Three positions were taken in regard to the residence of sovereignty. Calhoun, who is the clearest exponent of the belief in Commonwealth sovereignty, declared that when the connection of the colonies with Great Britain was broken each became an independent Commonwealth. Each was as truly sovereign as Great Britain itself. When the Articles of Confederation were framed, they constituted a league between the contracting Commonwealths, which, through its Congress, was to deal with certain matters of common interest, but not to trench upon the sovereignty of the Commonwealths. The Constitution of 1787 , said Calhoun, did not change this condition of things, but only made the principles of the Articles of Confederation more effective in securing the ends of the league. To his mind there was no American nation, as we would understand the term, therefore there was no national government. The Commonwealths retained their sovereignty and therefore had the right to nullify any laws enacted at Washington which were not acceptable to the Commonwealth concerned. Secession, from this standpoint, is only the withdrawing from the voluntary league, whose treaty, the Constitution, was no longer acceptable to the contracting parties. Secession would, thus, not be in the nature of rebellion, but only the ex- 
ercising of the legal privilege of the Commonwealth.

The national view held that it was a nation, not thirteen colonies, which declared its independence of Great Britain. The Articles of Confederation, which treated the Commonwealths as sovereign bodies, did not express the facts in the case.

When the struggle for leadership of the German people came in I866 between Prussia and Austria, the ambassador of the former said: "His Majesty, my king, will not regard the national foundation upon which the confederacy rests as destroyed by the extinction of the confederacy. Prussia holds fast, on the contrary, to these foundations, and to the unity of the German nation under the transitory forms of expression." This was the nationalist view of sovereignty in the United States, that in spite of all expressions to the contrary, in statute, and constitutions, there was existent, beneath all transitory forms, a national life. In this national life, sovereignty resided and not at any time in the respective Commonwealths.

Webster's position, which has been accepted until recently in legal treatises, rested upon a compromise between the idea of Commonwealth and of national sovereignty. $\mathrm{He}$ held that the respective Commonwealths became sovereign on their separation from Great Britain, thus agreeing with Calhoun; but he said that when the Constitution of 1787 was framed the Commonwealths surrendered a portion of their sovereignty to the Union which was then formed. According to this view, sovereignty was divided. Such a compromise could not be 
final, and the question of where sovereignty resided was submitted to the arbitrament of war.

When one understands that sovereignty resides in the will, he sees why Webster's contention failed in philosophy as it also failed in politics. There is not a division of sovereignty between the Governments of the nation and the Commonwealths, since sovereignty rests not at all in either, but in the will of the State which constituted the Governments of Commonwealths and nation. There is one people, not thirteen or forty-five. There is one will in control, which is morally responsible for national action; one sovereign power resting finally upon the justice of the action.

In the matter of sovereignty, legal decisions are adjusting themselves to the historical facts, so that the former difference of view between the historian, who held sovereignty to be indivisible, and the lawyers who followed Webster, is mainly reconciled. The latest legal treatises accept the former doctrine.

Sovereignty Can Not Be Delegated.

Authority to act may be delegated by the sovereign, but sovereignty can be alienated only by the extinction of the State. This is clear when the subject is considered from the psychical point of view. Sovereignty belongs to the social will, so that the loss of one means the loss of the other, also the loss of personality. Texas gave up its sovereignty when it came into the Union, and it gave up at the same time any independent choice of action. Henceforth its course must be guided by the will of the American State. The sovereignty once surrendered 
is as though it had not been. The State delegates authority to its Government, but sovereignty remains with the State. From the facts at hand, it is evident how far the materialistic conceptions of the State led us away both in political theory and practice. Had it been understood that the State was psychical not physical, spiritual not material, the long contest over the division of sovereignty either would not have occurred, or would have had to choose some other conditions of warfare. It is of no small account in the progress toward political harmony that we are coming to understand better the subject with which we have to deal.

The Location of Sovereignty.

Hegel tells us in his "Philosophy of History" that in the time of the early monarchies one was free, later the few were free, now all are free. Taken with some allowances, this expresses the truth of which history marks the unfolding in the process of the centuries. In the early empires the king was called the sovereign, though we accept the term with a proviso. Taking Egypt as a concrete case, the Pharaoh ruled in autocratic fashion, yet there were bounds to his authority, beyond which the king ventured at his peril.

The King Was Limited in His Sphere of Action.

The modern Government legislates in regard to the relations between citizens to an extent not possible to the ancient king. His range of subjects was limited, though in his particular field he had little restraint. The ancient Government was scarcely more than a taxing agency, and 
if the subjects paid their taxes without undue complaint, besides furnishing levies of men for the suppression of rebellion in the empire, or the subjugation of surrounding peoples, the monarch did not interfere in the other spheres of life. The general course of the life of the people was regulated by influences with which the king did not presume to interfere.

The modern Government steps in between citizens to regulate contracts, to decide on the methods of inheritance, to make conditions for legal marriage and divorce, filling the modern statute book with rules on subjects with which the Pharaoh did not concern himself. It is doubtless true that the growing complexity of modern society, of which Mr. Herbert Spencer makes so much, calls for Government interference in a way that the sim'plicity of ancient society made unnecessary. Yet even 'then they had to buy and sell as now. The difference lay not so much in the different conditions in society as in the change in the idea of the functions of Government. The king wanted money for his court, and men for his wars and public works. Gaining these ends he was content to allow the subject to follow the customs of his fathers in other matters. It was in custom that ancient society read its code of laws. These customs had been sanctified by immemorial usage. They had grown up less by conscious intent than by unconscious adaptation to existing conditions. Yet the point we should keep in mind is that they were the expression of the life of the people. Thus the people were ruled by laws of their own making, rather than by any device of the king. The 
Pharaoh might drive them into his army, or by thousands into the quarries, but to have interfered in family relations, or to have changed a religious rite, might have raised a storm which would have swept him from his throne.

The King Issued Decrees for Special Cases.

We think of a law which is enacted by the legislature as a standing rule for the settlement of a whole class of cases, a rule which by the interpretation of the courts may meet the needs on that particular subject for decades. In this sense the ancient king did not issue laws. He sent out decrees for special times and cases, and these edicts ceased to have force when the special occasion passed. The laws of the Medes and Persians could not be altered, for which there was less need on account of their special character. Ahasuerus, as the book of Esther records, issued his decree against the Jews for a certain day, and the order could be amended only by a new decree. The only rules which had general application at such times were found in the customs of the people.

When Hegel writes that one only was free in the early society he means that only the king consciously chose his own course. It is doubtless true that the people had scarcely come to consciousness of having any end beyond mere existence. We could hardly speak of any defined social ideal as yet. The power which the people possessed was mainly that of resistance to change. There doubtless were those who had insurrections against es- 
tablished conditions brooding in their minds, but they could not infect the multitude with them. Patriotism was yet far in the future. In such a condition of things, where was sovereignty located? Was it in the monarch? Was it his will that shaped the course of things, or did his will have to adapt itself to the established order? The latter seems the necessary conclusion. He might tax, he might kill, but he could not change the customs of the people. The absolute king seems to belong to the realm of fancy, rather than of fact; he finds his place in story, rather than in history.

The Few are Free.

In the growth of common consciousness, the monarchy gives way to the aristocracy. Not that this has been the universal rule among the peoples, for, taking the world as a whole, development seems to have been the exception rather than the rule. In many cases the particular society seemed to have reached the limit which its political genius allowed, without passing beyond the monarchical stage of development. Wherever societies have reached any high degree of development, the king has been displaced in reality if not in name.

The Tarquin Kings of Rome tried to hold their position by granting certain privileges to the Plebeians, but the Plebeians had not enough political organization to sustain the Tarquins in this purpose. For this reason the kings were driven from Rome by the Patrician aristocracy. The early Roman Republic was an aristocracy, with the political administration carefully guarded in 
Patrician hands, and the struggle for three hundred years was between this aristocracy and the rising spirit of democracy.

In England this order of development seems to be reversed, since the power of the king rose to its greatest height out of the ruins of the feudal aristocracy; yet the power of the Tudors lay mainly in the fact that they favored the commons to such an extent that they were among the most popular of English kings. The last of the Tudor line, "the good Queen Bess," was, undeservedly enough, the most popular of all, since she knew so well when to yield to the wishes of the people. The power of the Tudors lay, as does the modern Government, in the approval of the people.

The aristocracy of birth has had its time to reign, and has passed away. The aristocracy which now bars the road toward democracy is the aristocracy of wealth. Mr. Herbert Spencer looked forward to the time when the control of society would lie in the industries of the time, instead of in the legislative halls, and he has proven to be more of a prophet than many of his critics, since present conditions go far toward the realization of his idea!. The Government of the United States must have its conference with Wall Street, and the English Government with Lombard Street, before deciding on important matters. The press, which is to educate the people on the great questions of the day, depends upon its advertising pages rather than upon its editorials for its livelihood, and the former control the latter. It is the advertising agent who mainly dictates the make-up of the paper. 
The same is true in a less degree of the pulpit and the school. In the anxiety for endowments, the schools must cater to the sentiments of those who have grasped the world's wealth. The aristocracy of religion, and later of birth, held dominion over the minds of men, while that of wealth holds their bodies in fee; but the plutocracy must pass away, as did its more honorable precursor. The feet of those who carried out its predecessors are at the door, and not all the subserviency of press, pulpit and school can keep democracy from its own.

Sovereignty, so far as it is realized on earth, rests in the will of an aroused people. At one time the king assumed to have it, and for the time his claim seemed valid; the aristocracy seated itself upon the throne which the king vacated, and grasped with firm hand the reins of power; they too have passed, and will pass, away. Where superior mind failed to keep in the saddle, concentrated wealth need not hope to hold its seat. In our own time we read how the kings and the nobility of Europe bow in awe before a group of American millionaires. It is the new aristocracy which is graving its laws deeply on the political methods of our day.

There is but one influence that can stay the coming of democracy. When the moral decay which followed the Punic Wars had sapped the vitality of Roman life, the citizens lost that moral fiber which is essential to the people possessing self-government. The people had their consciences blunted by the plunder of the provinces which fed them, by the feasts and shows which made them careless of the suffering of the provincials, at whose 
cost these had been gained. To quote from Mr. Kipling, Rome was bearing the "White Man's Burden" of subject populations. Under such conditions the Roman citizenship degenerated so that it became the prey of the demagogue and the barbarian. Brutus sincerely believed that with the death of Cæsar the Republic might be restored, but it was too late. Only a moral citizenship deserves self-government; only such can retain it.

It is at such a time of moral degeneracy that the Cæsar comes. Since sovereignty is in the will, it follows that when a State becomes so corrupt as to lose its will power, as does the individual under like circumstances, some rival people comes to build upon the ruins of a fallen race. In this way can sovereignty pass from a people, but it is to another people more worthy of it.

\section{All Are Free.}

This was the final stage in Hegel's plan of human development. We have seen that in the previous stages the monarch, or the aristocracy, had claimed to be sovereign, but back of these administrators there was the people with the possibilities of rebellion. It is true that these uprisings were infrequent, yet their possibility acted as the fear of a strike upon an employer who has many orders on hand which he wants to fill. The possibility of revolution was the sword of Damocles which hung over the king and the nobility to remind them of how carefully they must do their work lest the blade should fall.

In the modern State it has become something short 
of a vice that the Government is afraid of the crowd, so that in listening for the popular verdict the Government has little of the leadership which it should exercise. It is the aim of the statesman of the present to follow, rather than to lead, public opinion, satisfied if results show that he has charted correctly where the tide is running, so that he may keep his political craft where the water is deepest.

\section{Is Sovereignty in the English Parliament?}

While the reasoning here followed denies sovereignty to the Parliament, many writers on law hold that as there is no constitutional restriction upon what Parliament may do, therefore sovereignty resides in the king in Parliament. This seems to be mistaking appearance for fact, since Parliament follows public opinion with scarcely less subservience than does Congress. Parliament has something the character of a constitutional convention, as it is within its legal competence to work an entire change in the British Constitution of Government, but the members have a clear understanding that they must go back to their constituents to give an account of their stewardship. Parliament is the last legal court of review, but the people have it in their power to change this court and its decisions at any time.

It is not necessary, as in the United States, to submit constitutional changes to the popular approval, but the difference is rather in method than in principle. The legislators must submit themselves to popular approval, So long as Parliament is in session there are no legal 
limitations upon its functions, but the dissolution brings the whole issue before the electors, much as if they were voting upon the measure directly. If the people wish to reverse the decision of Parliament, they can choose other members in that body.

\section{England's Three Revolutions.}

Professor Burgess states that England has had three revolutions. The first one took place in the reign of King John, when the barons in alliance with the leaders of the commons forced in Magna Carta the limitation of the royal power. It is true that King John kept the semblance of legal form by giving the Great Charter by his royal will, but it was a consent which he dared not withhold. "They have given me four-and-twenty over-kings," he said as he rolled upon the floor in his chagrin, and, except at intervals, the "over-kings" remained. Many times in the following centuries the Charter had to be re-affirmed as the kings tried to break through the limits which had been set to the royal prerogative. They had walked a road which could not be retraced.

The second notable change took place when the first Tudor set the crown upon his head in 1485 on Bosworth Field. During twenty years the Wars of the Roses, with their accompaniment of executions and confiscations, had worked such havoc among the feudal nobility that it was not after that time an efficient check upon the king. Thus the revolution of 1485 eliminated the nobility and left the king face to face with the people, whom he hence- 
forth was to serve, though not always with a good grace.

But as yet there was no institution through which the will of the English people could direct the Government. The Commons was yet a kind of assistant of the Lords. The Courts of Star Chamber and High Commission, though they later earned the hatred of the people, were designed to coerce the weakened nobility. It was when the king turned these courts upon the people that the reaction came which overthrew both king and courts in the Puritan uprising. During the years from 1485 till 1832 the king was allowed to keep the semblance of power, provided that he was sufficiently modest in its exercise.

The third revolution was in 1832 , when the people took over the exercise of the powers of the State. Up to that time the members of the Commons had been elected from the same districts as centuries before, though the population had moved meanwhile. The result was that large cities such as Liverpool and Manchester had no representative in Parliament, while villages, so ruined as not to have a house to mark the place where they had stood, sent representatives to Parliament. By this means these pocket boroughs, as they were called, the members for which were appointed by some Lord, controlled the actions of the House of Commons. The Reform Bill of 1832 abolished these boroughs, distributing the representation according to population, making Parliament the exponent of the social 'will. Again it may be said that the action of 1832 was not revolutionary, since it was legalized by the crown; but when it is remembered that 
the ministers ordered out the Horse Guards, compelled the king to dissolve Parliament and to consent to the creation of new Lords if the existing House did not consent to the Reform Bill, it is apparent that the royal prerogative had gone into eclipse. The last court of appeal is neither king nor commons - it is the people.

Conditions of Freedom.

So far the argument has led to the conclusion that the people have been, and are, the sovereign power, though it may be recalled that the State is not unlimited in its actions. Sovereignty in full realization belongs only to that will which is unlimited in its choice, and as well in its use of means for executing its will. The State, then, is not finally sovereign. Only in God is found the will which meets the conditions. In this conception of sovereignty is also found the essentials of individual freedom.

If it is concluded that the people is the ultimate sovereign, this power must find expression through the majority. If that is all that we have reached through the centuries of progress, it means that we have changed from the king, who had the semblance of sovereignty, to the people, which has much more of the reality, and that any sufficient guarantee of individual freedom is lacking. With the monarch it is possible to reason, scarcely with a million men. Against the king it was possible to appeal to the multitude, but to whom against the multitude? There will always be minorities in a democracy, however common the ideas of the time; indeed, 
it is to this social variation that we must look for progress.

Mr. Lawrence Lowell in his "Essays on Democracy" points out the same danger when he says: "It is clear that where absolute power is vested in any man or body of men, the rights of the individual depend on the will of that man or body; and this is no more true in the case of a king than in that of a legislative assembly or a sovereign people." We have seen how the king gave place to the aristocracy, and how this body, in its turn, had to acknowledge the power of the democracy. It is now left for the democracy to confess the authority of God in the matter of social control and the goal of history will be reached. In any will short of the will of God, sovereignty is relative; in Him it is absolute. It is in this that we have our only guarantee for individual freedom.

With God as the sovereign, we have an arbiter who is free from the intolerance of the majority and the passion of partisanship. Nowhere short of God is there a judge who has a care for the weak, which puts them on equal footing with the strong. It might be objected at this point that while God is sovereign, yet He must act through human means; that this human means must be the dominant social force, which is expressed through the majority. This might seem to lead back to the same result as before, the tyranny of the majority. But this does not state the whole case. The State must be ruled through the social element which is dominant at the time, but this majority should understand that it is not 
the final judge in the case. It should remember that it is under law, to which it must give account, and that the question between the majority and the minority goes on appeal to the judgment of God. The case may be allowed to stay on the divine docket for decades or centuries before judgment is pronounced and execution ordered, but when the bill is rendered it will be with costs.

Injustice will inevitably meet its recompense of reward. When the State recognizes its will as subject to the will of God, then, and not till then, will the individual have a guarantee of freedom sufficient to protect him from arbitrary power.

It is frankly admitted that the social intelligence must finally put its interpretation upon the divine law in its application to the matter in hand, and it is always possible that this interpretation might not be the one which justice would demand; yet it is not to be forgotten that the people taking the law of God as the rule of life has not worked social injustice to the citizen. Social freedom would not meet immediate fruition even on this basis, but in no other way will it be gained at all. It is when the State consciously accepts the will of God as supreme over the social will and carries out the social functions in the spirit of the teachings of Jesus Christ, that the will of God is done on earth as it is done in heaven.

The Nature of the State, Willoughby, pp. 181-309; Essays on Government, Lowell, pp. 189-223; Political Science, Burgess, part 2; Works of T. H. Green, vol. 2, pp. 427-549; American Republic, Brownson. 


\section{LAW}

THE philosopher who teaches the eighteenth century idea that we know only unrelated phenomena is lonely in these days as the owl upon the housetops, since materialist and idealist maintain that there is a universe constituted by universal law. It is evidence that ideas have not been simply marking time during the last hundred years, when the philosopher, the scientist, and the theologian have this much in common, however much they may differ in regard to the nature of this universal law. When the question of the nature of the law is broached, these quondam friends fall apart and each goes his several way. One of the questions which bring out this difference of view is that of the origin of law. Is Law Personal or Impersonal in Origin?

"Of law," writes Hooker, "there can be no less acknowledged, than that her seat is the bosom of God; her voice the harmony of the world." This sentiment states one view of the case, in declaring that law is an expression of will. It teaches that in the administration of the universe of men and matter there is a sovereign will at work which originates and directs both psychical and physical movements. These movements are not along blind alleys which are liable at any point to be marked "No thoroughfare." Each one is telic in character, having an end to serve in the universal plan. 
So far as the Middle Ages produced anything deserving the name of history, it was written from the standpoint of the ecclesiastic, and was scarcely more than a brief record of the doings of the churchmen. Somewhat later the historian gained a new vantage and gave us a record of the rise and fall of kings and courts. In recent times we are told that the economic factor is the most important in the matter of social growth.

What the student comes to understand is that each of these-the ecclesiastical, the political, or the economic - is but a different factor in the social movement, each co-operating with the others in an organic relationship in working out the plan of God in the uplifting of society. In this wonderful social plan each man and each institution has a work that is to minister to the final end.

It follows from this evidence of the complexity of the plan that the will which designed and moves it all is supreme intelligence. The universe starts from God and moves to God. That is its origin and its end. At no point between origin and end is either the molecule of matter or the individual man free from the control of the sovereign will. This will must belong to a person, since things do not have will. It is the personal will of a personal God.

Those who claim in this age that law is impersonal teach that natural law controls the world in which we live and that natural law is physical. The laws of attraction and repulsion govern matter; so they tell us that they govern man. In this materialistic view of things there is no spirit, except as it evolves from matter, so 
there can be no spiritual laws. Our common idea that nature is dead, passive matter, we have borrowed from the physicist, and yet, though we took part of his premises, we blame him because he wants us to go the rest of the way with him in admitting that this nature rules. Our mistake has lain in taking his premise as our starting point. Nature does rule, but is the clod under my foot nature? The clod did not make itself, it does not rule itself. There is something beyond the clod, and that is mind, that willed the clod. To find nature we must go beyond what our feet tread upon, to what our thoughts reach after, and find mind. Matter is neither a beginning nor an end. It is but the means through which spirit finds expression. Nature is sentient, it is God, and all the laws which we see working in matter the falling stone, or the running stream - are but one phase of nature's laws. All law emanates from the spiritual nature and acts for it.

As a side issue on this point we have the question of miracles. It is said by the materialist that miracles are a violation of the laws of nature, and therefore that they are impossible. But if we deny his premise that physical law is the only natural law; if we hold that nature is the divine mind, it changes the whole situation. Then from the standpoint of the divine mind, the departure from the observed course of things is not only possible, but, taken in connection with the life of Jesus Christ, is certain.

The laws which God gave to Moses at Sinai were natural laws, were the revelation of man's nature to him- 
self. The moral law was his constitution, just as the physical laws reveal the constitution of the rock and the soil. But neither man nor the rock gave law to themselves. That was given by the maker of both, that nature of which they were the expression and whose will they were to perform. In the final analysis nature is God. It is not passive, but active; it is not dead matter, but living mind. The miracles, of which Jesus is chief, obeyed the law of mind.

The Impersonal Origin of Law.

If this were written for the people of the East, it would be in place to take up the question of Pantheism, which teaches that God is in everything and that everything is God; but when one is writing for Anglo-Saxon readers the Pantheistic idea of law needs no more than a passing notice. The Pantheist would hold with the preceding view that all law came from God, but it would not be an expression of will. Pantheism has no place for a personal God, and an impersonal God, one that has no existence except in what the eye can see, can have no will.

But for the American, or the Englishman, having before his eyes the mechanical inventions which have made the powers of earth and air his servants, living in the midst of a production of material wealth such as the world has not known at any previous time, materialism is the dominant idea. Paradoxical as it may seem, as the mind of man is able to conquer matter and make it work for him in the field of action, matter is inclined to dominate man in the field of thought. "Things are in the saddle," so that man is in danger of owning as his master what was meant to be his slave. From the 
standpoint of the materialist, law is that uniformity of action which may be discovered in the laboratory, or by daily observation. It is simply physical law, and if there is a God at all $\mathrm{He}$ does not interfere in the operation of this law. There is no will in control. Mr. Herbert Spencer, who has earned the right to be taken as an exponent of materialism, teaches that law is only persistent force working through the material world and through society. All things come from matter and motion, says the great Agnostic, so that thought itself is but a physical product of some reaction in the brain. There is no will in control, no mediator to stand between man and the inevitable laws of persistent force, so that the mills of the materialistic gods, while grinding slowly, will " grind exceeding small." This universal law may possibly be adjusted to some remote end, but it is to work as remorselessly as the law of falling bodies. Such is the origin of law as the materialist sees it.

The man who takes the Bible as the rule of his life is not left in doubt as to which of these views of the origin of law he will accept. If the materialist has any place for God at all it is as the Creator of a universe which $\mathrm{He}$ at once abandoned. He has no place for conscience in regard to the application of the law. The whole duty of the individual is done when he submits to "persistent force," which in social affairs would be the rule of the environment. One does not need a conscience under such conditions.

The Definition of Law.

Any adequate definition of law should apply equally 
well in the material and in the spiritual realms, for when we reject the idea of the materialist who, in his limited view, denies spirit, it is not necessary to take the position of his equally one-sided friend who maintains that matter has no existence. One needs to look at facts with both eyes open.

Law might be defined as "the will of God," but it carries with it the possible implication that law is something imposed on the world from the outside, instead of being, as it is, its constitution. The universe was not made first and then a law made for it, but the law was made in it. Montesquieu has given us a definition which seems to be sufficiently near to the facts: "Law is the necessary relations which pertain to the nature of things." When the student is trying to discover physical laws in the laboratory, he does it by bringing different substances together to see what they will do. He finds that by mixing oxygen and hydrogen together in certain proportions he produces water. Two substances, each in itself harmless, when combined become a dangerous explosive. By experiments the student learns the actions of the acids and salts with which he has to deal, and these relations constitute their laws. In each case the law, or relation, is determined by the nature of the substance. To work any change in law it would be necessary to change the nature of the substance in question, since the law is something in it, and not an external power imposed on it.

When we turn from the matter of the laboratory to man, the definition still meets the conditions. The relations between man and $\operatorname{man}_{1}$ taken with the relations 
between man and God, make up the sum of psychic law, with which we have to deal. When Jesus said, "Thou shalt love the Lord with all thy heart, and thy neighbor as thyself," $\mathrm{He}$ was stating the relationship which pertained to the nature of God and man. As man comes to understand God better and his neighbor better, he is learning the constitution of both parties, so that he is able to live according to law. When a man does wrong he is violating his own constitution. A social wrong is a violation of the social constitution.

The Knowledge of Law.

As we have noticed two ideas in regard to the origin of law, there are also two views as to how we come to the knowledge of law. Those who believe that law is the expression of the will of a personal God, believe also that our knowledge of law is gained partially through revelation; while their opponents who allow only a physical character to law, claim that it is learned onlv through observation.

\section{Knowledge Through Experience.}

It must be admitted at once that a large proportion of the knowledge of our relations to men and things has come through experience; perhaps much the larger part has been gained in this way. But we can not allow experience the whole field to itself. One difficulty with making experience the sole discoverer of law is that it can deal only with the past, and only inadequately with that field; while it can give only suggestion for the fu- 
ture. It can give us a fair idea of where we have been, but can only infer the point toward which we ought to aim. In other words, it fails to present the ideal law which we ought to realize. The oarsman who sits with his face to the stern of his boat may, by watching the points on the shore which he is leaving, reach the desired landing on the other shore, if the shore is in sight. But if a long distance intervenes, the points on the shore cease to be a guide and he has recourse to his compass.

If history only repeated itself, if the future were only the repetition of the past, experience might file its claim as the agency through which law is made known; but experience fails to furnish the ideal toward which we ought to aim. Neither present, nor future, repeats the past.

Nor does it appear that experience may rightfully lay claim to a monopoly of the past. Man might in time have discovered the moral law, by means of a long and painful experience, but that was not the way in which it was learned. The child would learn by experience that the fire will burn its fingers, but the mother makes a revelation of the fact, with some saving in time and tears. Experience is a slow and expensive method of gaining knowledge, though its lessons are remembered. But much of our knowledge has not been gained, and could not be gained, by it. It fails to give the complete outlook on human and divine relationships.

Knowledge Through Revelation.

This is the factor which gives us what experience fails 
to furnish, and contributes the unearned increment in knowledge. By experience we gain information about material things, for our senses are continually active in this work; but experience utterly fails to furnish intimate knowledge of God. When Peter made his confession, "Thou art the Christ," Jesus said to him, "Flesh and blood hath not revealed it to thee, but my Father which is in heaven." In other words, there was a relationship discovered which came not by observation. This became a part of Peter's experience, but it came through revelation. It was the promise of Jesus when he went away that when the Spirit was come $\mathrm{He}$ would lead men into all truth. This truth was to be gained in no other way. After it had been once gained, experience might aid greatly in its development, but while experience may recombine what has been gained, it can furnish little that is new. The error of those who claim that all our knowledge of law is derived from experience is nearly akin to the error of thinking that all law has a physical origin. Each of these views is a partial truth. Having given to experience all the place that it can reasonably claim, revelation must be brought in to account for our spiritual knowledge. Thus experience and revelation complement one another, each having its function to perform in making us conscious of our relations to all that is outside the self. Thus far we have been considering the origin of law in the constitution of matter and spirit, and also the way in which we attain to the knowledge of the law. It is now in order to outline the method by which the knowledge of the law is put into objective 
form in institutions and statutes, so that it may work out the function of law in social control and development.

Early Forms of Law.

When we turn to the study of the early forms of law, two opposing views appear, each claiming the whole field to the exclusion of the other. One of these schools of law holds that law is first manifested in the form of custom, while the other as stoutly insists that legislation furnishes the first form of law. It will probably be found, after due consideration, that each view has part of the truth and that both will be needed to explain the facts in the case. In general it may be said that the German writers presented the early form of law as custom, while the opposing idea found support among the English lawyers.

Among the German writers on this subject Savigny has fairly earned the first place. He did his work at the time when the aggressions of Napoleon on the German people had awakened Prussian patriotism to the point of making a determined struggle for a national existence. The King of Prussia had been so influenced by Napoleon that the rise of nationality took place without his leadership, or even his favor. It was a movement of the people which opposed, or ignored, the king, and in such a time it was natural that a writer who was in sympathy with the new spirit, which finally forced the War of Liberation, should look to the people rather than to the king as the maker of law. Whether it was the historical situation or the result of his investigations, Savigny held that 
customs were developed as naturally as language. Both came out of the people.

Some explanation has been given in a previous chapter as to the way in which custom comes into existence. The customs would not, at first, be common to all.

Individuals would adopt a certain practice, and if it proved fit for the existing conditions, the practice would be copied by others until it became uniform. As soon as custom arrived at this stage, it would act as a restraint upon unruly members in their violation of the common practice. It is evident that these customs do not arise from the arbitrary decisions of any individual or group, nor do they hold sway simply through the popular assent. Rather do they have a positive sanction in the will of the community, since they are the expression of the life of the community. Reason is not a prominent factor in the formation of social customs; they are not reasoned out. But while this is the case, the development of custom has, more or less, the character of a conscious social purpose. It is what the people wanted, else it had not taken the form of custom.

For instance, when the three-field system of farming was introduced, by which they arranged that a field should be used as meadow, grain, and pasture land in successive years, it was probably through the suggestion of some shrewd cultivator who saw that the continual cropping of the soil would unfit it for use; but the act would become customary through the fact that it suited the conditions of agriculture and of society. When once this custom had been settled, there was no doubt among the 
farmers as to what ought to be done, so that the field was plowed, or mown, or pastured, according to the prevailing rule. No one would think, at least till fertilizers were devised, of departing from the rule which custom had fixed. Under such conditions there is no need of a statute to define what ought to be done, nor of an official to enforce it. The common judgment, based on the utility of the practice, is quite sufficient to give sanction to the rule.

In the early communities, when men were simple herders, or tillers of the soil, life would be so simple that the rules of custom would furnish much the larger part of the means of social control. When new employments bring in a division of labor, so that sowing and reaping, grinding the grain and weaving the cloth, are no longer done by a single person, life becomes so complex that customs fail to serve the end of social control. Sir Henry Maine has been the chief exponent in English of this view of the early form of law. Taking India as his field of study, he considers the village community the earliest form of society and in this community there was no enacting of law; everything was ruled by custom.

\section{Decrees the Earliest Form of Written Law.}

The reason why one should call the early enactments decrees, rather than statutes, is because the king, who was the lawgiver, issued special orders for special cases, instead of laying down a general rule to cover a whole class of cases. In discussing the legal conception of the term "state," in one of the previous chapters, reference 
was made to the views of Hobbes. The central idea of the legal system of Hobbes is that law is a command issued by a sovereign to a subject, and depending for its enforcement upon his superior might. Contrary to the conditions where custom is thought to rule, force is here the chief factor in law. It is for the sovereign to command; for the subject to obey. As has been suggested, the first commands are aimed at isolated cases, only in more advanced legal conditions are general rules formulated.

Without going at length into a discussion of the development of legislation, it may be said that the theory of law studied in our law schools is derived from English sources and is drawn from Hobbes. Now it is clear that if law comes altogether through the act of the legislator, be it king or Parliament, custom is ruled out of the question. But the flaw in this conclusion, which shows that it is invalid, is that history furnishes abundant evidence of a rule by custom. The conception of Hobbes was not based on a study of history, but on a philosophical theory which was altogether unhistorical. Yet, in this case, as in the conflicts previously noted, we get at the fact by combining the truth which is found in each claim. Custom has its place, but it fails when society becomes so complex that difficulties arise with which custom can not deal. This situation calls for the legislator who cuts the knot with a statute which becomes a rule in all like cases.

One of the defects of custom as law, lies in the fact that changes must be made very slowly, if macic at all. 
A government administration is scarcely more than a mouthpiece for the average man if it is only the executor of custom. It is for this reason that legal development will be necessarily slow if it must wait the growth of custom to put the new idea into general practice. In early society custom was the usual rule and changes came about very slowly, legislation playing a very small part in the work. But with social development, legislation steadily encroached on the field of custom, until at the present time legislation has nearly driven custom from certain spheres of social control. The regulation of the home is left to custom, but nearly the whole field of business operations, which make so large a part of modern life, is occupied by legislation. Nor does it appear, from present indications, that Mr. Herbert Spencer's ideal of the abdication of government, is likely to be realized. Legislation is in continual demand to restrain this influence and to promote that one. Indeed it is the socialist ideal, in which legislation is in control in all spheres of lfe, that is looming up in the distance. To sum up the points suggested in the preceding paragraphs, custom nearly monopolizes the field of early law, while legislation holds a larger relative place with each century of development. The three forms in which law is known in modern usage are common and statute law and constitutions.

\section{Constitutions.}

Hamilton defined the constitution as:- "The declaration of principles by which we have chosen to be governed." 
According to this definition the constitution is made up of the principles, drawn from the life of the people, for the setting up of government, the adjustment of its different departments, with directions to guide each in the performance of its functions. The definition also brings out the necessary distinction between constitution and statute, in that the former has to do with principles, the latter with the application of principles. The constitution is but an outline of what the Government is to be and to do. When the constitution of the French Republic was drawn up in a convention which had a majority of monarchists, the outline was limited in such fashion that if the monarchists should be able to agree, a king could be brought in without any radical change in the French Constitution. Our own frame of Government is one of the briefest among the written constitutions, leaving to Congress, among other duties, the crescion of the whole system of federal courts.

Indeed, the Federal Constitution was much briefer than was palatable to many of the ratifying conventions in the Commonwealths and the first ten amendments, the American Bill of Rights, embody only a part of the changes and additions which were proposed by the Commonwealth Conventions. All these amendments aim at one end, the limiting of the powers of Congress, the people not being entirely satisfied with the statement of the framers of the Constitution, that since it ordained a Government of limited powers, it was needless to forbid the Government to use the powers which had not been given to it. It had been the fear of the people of that 
time, with the memory of George Third in mind, that the Government would encroach on individual liberty, therefore these amendments were adopted to guard the people against any excessive use of power by Congress. Still with these additions, and those added in connection with the slavery question, there is little in the Constitution which ought to be in statute instead. It is a declaration of principles which leaves their application to Congress and the courts.

In the Commonwealth Constitutions, on the other hand, there are many instances of non-constitutional provisions. These parts of the frame of government deserve the name non-constitutional, since they are not general principles such as properly find a place in the Constitution, but are rather the application of principles to remedy wrongs. It is for this reason that the Constitutions of the American Commonwealths do not in all cases conform to the definition offered at the beginning of this section.

The apparent reason for incorporating in the Constitution those legal features which belong in statute law, is the prevailing distrust of legislators. This is illustrated in the attempts which have been made to curb the aggressions of the liquor power. It was found that when the pressure of public opinion compelled a legislature to prohibit the traffic, the subsidence of the agitation was followed by the repeal of the measure. In order to prevent this setting aside of the popular measure through the influence of the liquor interest on the politicians in control, it was thought best in many Common- 
wealths to place the prohibitory measure in the Constitution, where it would not be subject to the will of the legislators. Iowa presents the novel situation of a prohibitory clause in the Constitution, which the legislature could not remove, while a provision is made in statute law that any parties paying a certain tax for the privilege of selling liquor shall be exempt from prosecution for the violation of the Constitution. A better safeguard of the public welfare would seem to lie in the election of officials who had a wholesome regard for the oath of office and for the social welfare.

\section{Statute Law.}

Statute law differs from the principles of government that are embodied in the constitution, not only in matter, but in manner of enactment. Our Federal Constitution, and the Commonwealth Constitutions for the most part, are ratified by some form of the referendum, while statute law is enacted by Congress, or legislature. The function of statute law is to apply the principles in the constitution for the solution of the various questions which arise in the administration of government. Guided by the constitution, the legislature has the duty of framing such measures as will repress the unsocial elements in society and encourage those that assist the social development. The older idea that the legislator had only the negative function of guarding life and property fits neither the present ideas, nor the present social needs. He has also the positive duty of directing the social forces into the most fruitful channels. 
This leads to the suggestion that the legislator has an individuality of his own and is not simply an executor of public opinion. Public opinion is fairly representative of what the average man thinks, and if the law was framed according to that standard, it would lift the thought of the man who lives below the average, while it might retard the man who had made greater advancement. Law is an efficient educator and therefore it should be as advanced as public opinion will tolerate. If any social advance is being made the statute will soon be antiquated and need replacement. It is unfortunate that this ideal conception of the legislator as a moral pioneer of public opinion is so far from the reality, since he is often inclined to legislate on the lowest level that will be tolerated. Professor Burgess has said that in America we have a democratic State with an aristocratic Government, and, taken in the sense in which it was meant, it expresses the theory of our Government. It was not meant to be a rule by the lowest, as is often the case, nor even by the average man. It was, in theory, a rule by the best men. As Carlyle stated it, the fittest should rule, and these should be the free choice of a free people.

This was the idea that lay at the basis of the original plan for the election of the President. Each Commonwealth was to select its most capable men and these men, meeting without instructions, were to cast their votes for the best man, regardless of party, for the office of President of the United States. While Washington was the candidate, the plan worked with success; but with 
his withdrawal from the field the party idea came to the front, so that the electoral college, instead of being a meeting of the wise men to deliberate as had been intended, became a mere device for recording the wishes of the voters of one of the political parties. Such a position gives neither honor, nor power, to the members of the electoral college, and it.comes near to expressing the idea which the average official has of his duty. $\mathrm{He}$ is to keep his ear to the ground in order to make his measure take the popular tone. Such men do not make the State, since they are politicians and not statesmen. It has been said that a statesman is a politician that is dead, but even this fails to win the desired title to fame in many cases. Unless the legislator is better able than the average man to judge "the relations which belong to the nature of things" and to crystallize these relations into statutes, history will scarcely write his name among the immortals.

\section{Common Law.}

It is difficult to state a working definition for common law which shall, at the same time, be brief and comprehensive. Perhaps no legal authority has succeeded better than Chancellor Kent, who defines the common law as "those principles, usages and rules of action applicable to the government and security of persons and property, which do not rest for their authority upon any express and positive declaration of the will of the legislature." According to this definition the common law is comprehended in the immemorial customs of the people 
and in the decisions of the courts based upon these customs.

The common law in this country includes in addition to the customs and usages of England which the colonists brought with them, the parliamentary guarantees of freedom which preceded the English settlement in America, since the most important part of the common law is that which concerns the liberty of the citizen. At different times in the history of England, statutes were passed declarative of common law principles. The first of these is the royal confirmation of common law principles by King John at Runnymede in I2I5. The Great Charter, as it was called, professed to be only a confirmation, of the good old laws with which the people had long been familiar. The second of these great affirmations of common law was the Petition of Rights, granted by Charles First, declaring again the principles of the Great Charter, which had been set aside through usurpations by the crown. The third of these acts was the Habeas Corpus Act, passed during the reign of Charles Second, which did not alter the principles of the preceding measures, but provided for their greater efficiency through their application by the courts. The fourth of these great English charters of liberty was the Bill of Rights, adopted by Parliament in the reign of William Third, which forbade the king to set aside the laws of the realm.

English and American liberty has its legal basis in the common law of which these acts form a part. They did not create the liberties which they expressed, but affirmed them for the guidance of the Government, which 
was inclined to encroach upon the rights of the citizen. The right of trial by jury, the provision that the accused shall not be compelled to testify against himself, belong to common law principles, which antedated the settlement of America.

While the common law, upon which the jurisprudence of the American Commonwealths rests, includes statutes as well as ancient custom, in later usage the line between common and statute law is drawn as in Chancellor Kent's definition. This difference does not lie in the subject matter, since the statutes embody, frequently, a principle which had been realized in the common law. When the principle is written in statute form it ceases to bear the name of common law.

It is a recognized maxim in law that we do not know the meaning of a statute until the court has passed upon it. Whatever the judicial decision may be on the case which comes up for action, that is the legal meaning of the law. This maxim, which applies specially to statute, is also applicable when the court is called upon to pass on long established custom, since the decision in this case defines the common law. Thus in both statute and common law cases, the courts interpret the law. A decision of the courts based upon custom has the same sanction as if based on statute. Both are enforceable by the ordinary legal process.

The question might arise at this point as to why common law was written in statute form at all, since it has equal authority in the former stage. The change becomes necessary through a conflict of customs, or of 
decisions based upon them, which requires a statute to settle the disputed point and give a basis for judicial action. So long as customs, and decisions upon them, agree it does not appear that the legislator needs to interfere. The rule of primogeniture in England, by which the eldest son inherits the landed estate, has come down from the feudal times when it was necessary for the king to keep the land in the hands of those who could come to his aid in war; yet while it has had such an effect on English life for centuries, it still remains a part of the common law. Statute law could not set out this principle in clearer outline than it has attained in common law.

Ancient Law, Maine; Law of the Ancient Hebrews, Wines; Law, Lacy; Spirit of the Laws, Montesquien; Early Law and Custom, Maine; Political Science and Constitutional Law, Burgess. 


\section{AUTHORITY}

Sovereignty finds expression through its two phases of authority and law. In practice these two factors may not with safety, be separated. Eliminate law from authority and it leaves only tyranny; take authority away from law and only anarchy remains. It is when they are used in conjunction, each performing its own function, that sovereignty works out the social end.

Authority Rests on Right.

Napoleon once said that we could do almost anything with bayonets but sit on them. We paraphrase the epigram of the Corsican by saying that while force is an essential element of authority, it may not be made its basis. History records many cases where illegal measures have been enforced by police powers, with a disregard of justice, but history also affirms that this has not been a permanent condition. Napoleon held Prussia in subjection through most of his campaigns, partly by means of his ascendancy over the mind of the Prussian king, though mainly by force, even compelling the Prussians to fight under his leadership; but the outburst of Prussian patriotism which crowded Blucher's regiments and blasted the hopes of Napoleon at Waterloo, showed that force could not repress national feeling.

Force mav be a temporary but not a permanent ae- 
pendence. Rousseau states the case when he says: "The strongest is never strong enough to be always master, unless he transforms might into right and obedience into duty." It is by this means that it occurs at rare intervals, that the conquest of the homes of a people is transformed into a conquest of their hearts. Charlemagne pushed his armies quite across the German lands, but while the conquest was won by the warrior it was secured by the priest. What had been subdued by force of arms was brought to loyal obedience by the Gospel. It was not many years after the bloody struggle, a generation long, that a Saxon monk, forgetting the heroic defense which his countrymen had made, sang the praises of the Franks who had brought them out of heathen darkness into the Gospel light. The highest loyalty is found only when it is given for conscience sake. Such loyalty the despot never earns and never knows. Authority appeals to conscience only when the rule is based on right. It is for this reason that righteous laws make for the stability and permanence of a Government.

Authority Is from God.

This follows from the proposition already demonstrated that God is sovereign. Authority always goes back to a sovereign, therefore authority finds its sanction in God. Paul writes in his political instructions to the Roman Christians: "The powers (authorities) that be are ordained of God." That is the final basis of all authority. The contest which was waged so long over. the question of inherent powers in government is easily 
resolved when the social structure is understood. Government has authority delegated to it to perform its duties, but it has no inherent authority to do anything. This authority comes to the Government from the State, but it is inexact to speak of any inherent authority in the State. That is not the final step in its location. God has inherent powers; institutions have that which is conferred on them by law.

Each one who exercises authority must derive it directly, or indirectly, from God. The official of Church or State, the father in the family, each traces, properly, the authority which he exercises to the common source. Authority may have passed, as in political affairs, through several intermediaries, but its ultimate source is the same. It is this fact which makes possible the co-operation of all social institutions, under a common authority, toward a common end. If authority is properly used, the family function will harmonize with the Church, the Government, the industrial order,- each aiding all others by doing its own particular work. All social institutions, provided that they have a legitimate function, are thus designed to integrate with one another in a harmonious system under a supreme will. It is for this reason, if for no other, that this conception of the social system should appeal alike to the philosopher who seeks a principle which will unify the social life, and to the man of practical affairs who is looking for daily guidance.

The Use and the Abuse of Authority.

While individuals, parents for example, have authority 
given them to direct and correct their children, it is possible to abuse the privilege. It is for this reason that, while the father has authority over the child, the community has found it necessary to limit his use of it. The various agents for the prevention of cruelty to children and to animals, witness to the fact that the administrator of authority frequently requires interference in his affairs. The policeman brings home to the parent who outrages the feelings of the neighborhood, the truth that the use of authority must be distinguished from its abuse.

Where should the limitation in the use of authority be placed? Evidently at that point where law is eliminated from authority, and mere force is used. Force used lawfully is authorized; used unlawfully, it is criminal. The father is arrested and punished who maltreats his child, or the driver who abuses his horse. The same principles apply with equal aptitude to other instances of the abuse of authority, though there is not always such ready machinery, or wish, to call the offending party to account. Authority is a trust which may not be held irresponsibly. If the user had inherent authority, there might not be any legal interference with him in its exercise. but there is neither individual, nor institution, that may claim such high prerogative. Authority must follow the provisions of law.

Delegation of Authority.

Delegation is the method by which authority is given by the sovereign to the subordinate agencies through 
which he works. Sovereignty may be surrendered, which means the lapsing of it, but may not be delegated. So long as sovereignty is retained, authority may be placed in the hands of any agency to carry out the purpose of the sovereign. The method of delegating authority may be illustrated by a business house sending out an agent to sell goods. So long as he represents the house, the salesman has explicit instructions in regard to his duties. He is informed as to the length of time for which credit may be extended, he is told the price which he may make to customers and the guarantees which may be given with the goods. So long as he keeps within the specifications of his instructions, he acts with authority, and the house will carry out his contracts. The agent has no authority to go beyond his instructions and does so at his own risk. In such a case he is acting without authority and his acts are discredited by the house.

\section{God Delegates Authority to Jesus Christ.}

God, as essential, does not deal directly with the individual, nor with the State. It is the explicit teaching of the Bible that after man had sinned, thus marring the image of God in which he was created, he could deal with the essential God only through a mediator. The mediation between God and man was effected by the death of Jesus Christ upon the cross and $\mathrm{He}$ becomes the mediator, the one who reconciles man to God and acts as the intermediary in all matters. It is, therefore, through Jesus Christ that God acts in his dealing with men and it is 
to Jesus Christ that all authority is delegated for the control of human affairs. This conclusion does not carry with it the idea that God is passive in social control, for since God is spirit, and it is in the nature of spirit to be active, to conceive of Him as passive would be impossible. God, the Father, is active, but $\mathrm{He}$ acts through Jesus Christ, the Son.

The relation and function of each person of the Godhead as set forth in the Bible, may be crudely illustrated by the division of labor among the partners in a business firm. Where there are three partners in the business house, one of them may give his attention to the sales department, another attends to the advertising, a third to selling the goods. This gives a division of labor and allows each member of the firm a special function, but it does not mean that the firm has been dissolved by such division of work. It has not become tinree independent workers, but has been differentiated for greater efficiency. Each member, notwithstanding his separate duty, perhaps because of it, is carrying out the will of the firm. The firm acts through him in his work. The firm sets him apart for that special work. By some such analogy may we understand how the administration of the world is given to Jesus Christ, and yet God be active in it all.

By the records in the New Testament, we understand how universally that control was exercised. In physical nature the birds, the grass of the field, the waves, the wind,- all owned his control. In the multitudes which thronged Jesus $\mathrm{He}$ banished disease, $\mathrm{He}$ restored the 
deformed, and made men spiritually as well as physically whole. Material goods $\mathrm{He}$ said would be added to him who put first "the Kingdom of God and His righteousness." The Gospel of John is prefaced by the declaration that Jesus Christ made the universe, thus giving an authoritative interpretation of the first verse of Genesis.

It was the idea of the ancient philosophers that all matter must be deduced from one original element so that there might be unity in all. Such is likewise the demand of modern science, when it searches for the principle in control. Without some such supremacy, science would be a thing of "shreds and patches." While the scientist may, and often does, reject the idea that the will of God gives unity to all things, he is compelled to put something in his room. There must be either supreme force of matter, or supreme will of mind. Science must have one or other of these premises. If the scientist rejects the will of God as the means of control, he is reduced to the necessity of making life and thought a result of some combination of matter and motion, he has to govern man by the same law as the pebble at his feet. What the scientist thus worships ignorantly, is declared in the teaching of the Christ. $\mathrm{He}$ is the "persistent force," His is the will which shapes "the fortuitous concourse of atoms" and regulates the "reasonable sequence of the unintended."

Science could not have a being without the universal presence of the Spirit which brooded over the chaos of the primeval day, except by deifying one of God's creatures in his room. The materialist insists on the necessity 
of a universal law, and the mind may not stop short of premising a lawgiver. Revelation brings in the necessary complement of science. The latter deals with the thing created; revelation includes the creator.

Jesus Christ claims to be supreme in the administration of the universe. In His conmission to His disciples $\mathrm{He}$ declares: "All authority is given to me in heaven and on earth." There is 110 reservation. A passage in the life of Jesus Christ which is sometimes misunderstood, occurs in the trial before Pilate when the Roman governor questioned $\mathrm{Him}$ in regard to the charge that $\mathrm{He}$ was organizing a rebellion against Rome in order to set up again the Jewish monarchy. Seeing that Pilate had not understood the purpose of His mission, nor the spirit of His teaching, Jesus said: "My Kingdom is not of this world." Not a few have interpreted this saying to mean that this is the devil's world and that the "Kingdom" means some state after death where the will of Christ is to be done. But such a view fails to satisfy reason, for the Christ who created and governs this world can not thus be evicted from his own possessions. It also fails to satisfy the text and the context. The word translated "of," in the saying quoted above, is a preposition having the meaning "out of," and means that His Kingdom does not have its origin in this world. It is of heavenly birth and earthly residence. The words of Jesus freely translated would read something like this : "My Kingdom is not of the kind that you suppose. It is not of the character of the world. If it were then would my servants fight, as do the followers of 
other rulers, that I might not be delivered to the Jews. I am to win a throne but not by sword and spear. My Kingdom is not from hence." With this reading agrees the word which came to John, an exile on Patmos, the one who penned the saying of Jesus just explained. "The kingdoms of this world are become the Kingdom of our Lord and of His Christ."

In an earlier chapter of this same Gospel of John, Jesus is quoted as saying of His disciples: "Ye are not of this world even as I am not of this world." We have here the same use of the Greek words as in the saying of Christ: "My Kingdom is not of this world," and if the Kingdom does not have any place in existing society, but only in some future state, the same must be said of the disciples. Few will claim that Peter and his comrades had not existence except in a future state. Such an interpretation is not well considered. However the present conditions may suggest an opposite conclusion, there is the explicit assurance in the Bible that the Kingdom which was inaugurated among men in the beginning will yet be realized on the earth. That was the purpose of the life and death of Jesus Christ and this purpose must be realized.

With this conclusion, philosophy and science are in agreement, since both look forward to an ideal society on earth. Comte reads this into his Positive Polity when he foretold the age when altruism would rule in the hearts of men, while St. Simon, the master at whose feet Comte had sat, thought like the disciples of Christ that the redemption of humanity was at hand. $\mathrm{Mr}$. 
Herbert Spencer prophesied the time when society would be finally differentiated, when matter would be integrated and motion dissipated, and when egoism and altruism would be in perfect equilibrium. It is the faith of the Christian that Jesus Christ is to rule on earth through the supremacy of His law in the hearts of men.

The Kingdom of God in the Old Testament.

The Kingdom of God is the ideal society in which civilization is to culminate and the Old Testament gives us a cross section of its development by tracing the history of the Hebrew people. For some reason, which was not its superiority to other races, the Hebrew was chosen to manifest to men the character and purpose of God. In the period which was covered by the Old Testament history, the individual was regarded rather as a fraction of society than as an end in himself. The institution was the important thing, whether family or tribe; the individual had his status as a member of these institutions. It was the period of group life. It may have been for this reason, in part, that God sought to make Himself known to men through group life, instead of through individual life. The Hebrew nationality was grouped about their conception of God. The prophets were primarily concerned with the life of the group rather than with individual interests. They were the patriots of the age who recognized that Jehovah eith^r prospered or punished the people according as they were obedient or disobedient to him. While they had their constitutional king and something corresponding 
to the modern bi-cameral system of legislation in the body of elders and princes of the congregation, it was recognized that the will of Jehovah was supreme in the conduct of affairs. So far as this idea was realized, the Hebrew people constituted a theocracy, the God-ruled. Any State which accepts Jesus Christ as its ruler, and His law as the rule of the social life, is a theocracy. To know His will the Hebrew went to the oracle or to the prophet; with our fuller revelation, we may go to the written Word.

The Bible from its beginning to its end is the history of the development of the Kingdom of God, and its prophecy is unrealized history. Though coming very far short of its ideal, the Hebrew State was a type of the Christian State which is not yet, but is to be. David in his reliance on God, though not in his grievous faults, is the typical ruler. Solomon proposes to extend his rule at the expense of the principle on which it rests, and the kingdom is rent to save the principle. The prophets foretell the triumph of the principle and the wonderful rejuvcnation of nature and man with which its perfect realization is to be accompanied. John the Baptist prepares the way for the Kingdom through his preaching, and gives baptism as the naturalization rite by which the Kingdom is entered. Jesus tells his disciples that the Kingdom is at hand, later, - that it is among them. The apostles proclaim it and organize themselves for its realization. With the ascension of Jesus Christ, the Spirit comes to develop the Kingdom in the life. The whole Word and work of God point to the realization 
of a process which has been going on through the centuries, the acceptance of the reign of Christ over the life of man in its every phase. This is the social consummation when the State shall be permeated by the Spirit and shall become the Kingdom of God.

Jesus Christ Delegates Authority to the Organic People.

God does not appoint any man, family, or class, to exercise political authority. He gives that authority to the people, not to certain individuals. To be more exact, He gives authority to the social spirit, the State. It is the divine purpose that the will of the spirit which is divine, shall find expression through the will of the spirit which is human.

Man was made with the necessity for civil rule. Hegel says truly that the human spirit is realized only in the objective world, the world of institutions. It must find expression through these to be itself. In an abstract way we might think of spirit as merely subjective, disembodied, but in reality man has never existed under such conditions. He lives and grows in the Family, the Church, the industrial organization,- - the objective world to which Hegel refers,- of which the State is the most inclusive institution. Because the State is the most inclusive institution, because that in it man comes to himself, it is to it that Jesus Christ delegates authority to administer social control. It is necessary that order be maintained, that disorder be repressed, therefore social control is a necessity for the realization of spirit.

The constitution of man's nature is the law wnocn 
he must follow if he is to work out his highest possibilities, or even make any attainment. By this constitution man's action must be voluntary, that is, it must be an act of the will. Social action must be the choice of the social will. It is, therefore, to this will that Jesus Christ gives authority in social affairs, this will which is held responsible for the work done. Now', this being the case, it is evident that Christ does not confer authority on any family, since the family is subordinate to the social will. The greatest thing in man is mind; the greatest thing in society is the social mind. It is to this mind that authority is delegated and thus the will of God purposes to find expression through the social will.

There is not a certain amount of social authority vested in each individual, say one eighty-millionth part of the whole in United States. No man has any authority whatever over another in civil affairs unless it has been given to him by the State, which is the sole legatee. This truth has its special application in these days when mob violence frequently sets aside the legal authorities. It makes no difference whether one man or a hundred men take the life of the supposed criminal, it is murder no less and each individual in the mob must answer for it to God, if not to the civil law.

The normal course of social action is for the State to make choice of certain ends after a review of the situation, though it is unfortunately true that frequently this consideration fails to take in the whole set of conditions. This is what makes the social or individual 
act faulty. When the State, acting through the Government, licenses the liquor traffic, there is the consideration of the revenue to be gained and, perhaps, some consideration of lessening the consumption of the beverage. But the social consequences are not fully considered. Since it is to the social mind that Christ delegates authority to deal with such issues, since the State is held responsible for the decision made, the social problems demand attention in all their aspects. The State, no more than the individual, is authorized to do wrong. It has the necessity of choosing, but must render account for the choice. To sum up the preceding paragraphs, it is to the State, the social spirit which is capable of reason and of choice, that Jesus Christ delegates authority.

In popular speech, social control is located in the will of the people. Does this will of the people mean the same thing as what has been called here the social will? Is the mind of the people of which this will must be a phase, simply the social mind? Does popular speech embody the latest teaching of social philosophy, the psychological view of the State? With proper qualifications it would seem that all these questions are to be answered affirmatively. The common mind has somehow grasped the great social fact which philosophers had obscured with their wisdom, and the main object of these pages is to interpret this social fact.

But who are "the people" whose will is in control? Does this mean a certain family, or class, or even some sex distinction? Evidently not, since will is not limited 
by any of these marks. It may be well at this point to recall the explanation previously given, that all those belong to the State who share in the social spirit. Now it is clear that those who share this spirit, must share in mind which is one of the attributes of spirit, and in will which is one of the phases of mind. "The people" whose will exercises social control are those who have the common mind. This would mean the whole population, so far as they are capable of forming opinions, with the exception of those who have not been assimilated to the national spirit.

That the voters do not comprise "the people" in this sense is evident since it is the State itself, acting througin the Government, that determines the qualifications of the voters, prescribing these qualifications either in constitutional or statute law. It is therefore evident that the will of the people does not wait for its existence until a voting class has been defined. The State is not defined by act of legislature since the legislature is created by the State. Whatever may have been the philosophy of the men in the Philadelphia Convention who framed the Constitution, the State is a historic fact and not a creature of law. This is clearly recognized in the popular phrase "the will of the people," for will is not brought into being by act of legislature. The fact seems to be that the writers on this subject have been led astray by legal terminology, while the common mind has gotten at the fact. It is a question in psychology and not in law. Everyone who has a part in the making up of the common mind shares in social control. The voters, more or less imperfectly, 
express this common mind, and a king if he were wise enough, might do the same.

The real gist of the question of suffrage for women is whether the social mind would gain a better expression if sex were disregarded in voting. It can not be a question of right, for a woman has quite as good a right to her opinion as a man has to his, so that if it is to be settled by her right, she should have the ballot. But the real question is whether the social will would be more clearly, more intelligently expressed.

Some writers have held that woman is the psychological complement of man, and that the State will not get full and clear expression in social action until women have a voice in political affairs. It is said, on the other hand, that this psychic element already finds a place, since it now influences the opinions which are recorded at the polls. The essential matter both for the individual and the social mind is that it have the fullest possible opportunity for development through expression. That is the purpose of the ballot.

\section{The Delegation of Authority from the State to the} Government.

Even as the will of Jesus Christ should act through the social will, so should the social will act through its institution, the Government. The Government is the agency through which the will of the State gets its greatest objective efficiency. Because of this fact it is necessary that the State should lay down its rules of procedure for the Government, so that the State may secure the 
objects for which the Government was set up. In order to make sure that this end shall not be missed, it is required in all States which have elective rulers that they shall take oath to carry out the will of the State as laid down in law. This would certainly not be necessary if the Government derived its authority from some other source. The point may be illustrated by various incidents in the history of England.

When the Norman kings gained the English throne, while the legal forms of coronation were gone through, it was evident that they owed their position to force of arms rather than the popular will and, therefore, they did not feel under obligation to adhere to the terms of the English Constitution. They felt themselves, in a degree, independent of the State. But when the Lancastrian dynasty came into power, it was through act of Parliament and they felt the necessity of ruling as constitutional monarchs. They had been raised to place by what at that time was the electorate of the kingdom, and to disregard its will would have cut the ground from under the feet of the ruling family. .Most modern governments recognize that public office is a social trust and there is no tendency to deny its dependence on the State.

The Constitutional Convention.

From the earliest period in American history, the constitutions have been framed in some form of constitutional convention which represented the will of the people. In England, however, although the Constitution is as truly a social product as it has been in America, the convention 
was not a factor in the process. The English Constitution which, though in written form, is scattered through the acts of Witan, Great Council, and Parliament, covering the period from Alfred to the present, required no convention; since, by the English method, the passage of a constitutional provision does not differ from the passage of an ordinary statute. In this way the Constitution is easily shaped to fit the changes in the social mind. In the case of the German Empire, the Constitution was formulated by the Emperial authorities, Bismarck having a chief place in the work, and accepted by the heads of the various German States as they gathered at Versailles in I87I, at the close of the Franco-Prussian war. The French Constitution was framed by the Assembly which was elected for the purpose of settling the terms of peace with Germany in I87I, though the Constitution was not made until I875. Neither in France, nor in Germany, was the Constitution submitted to the decision of the people. In neither case were those who framed the Constitution chosen for that particular duty. Yet the fact that it was acceptable to the State showed that it had the endorsement of the social will, even though that endorsement was not formally expressed.

The Convention which met in Philadelphia in 1787 to devise a form of Government which would be more suitable to the American State, was a representative body, chosen for the special task in hand. According to the terms of their call, they were only to revise the Articles of Confederation, but it was found that the social need could not be met without a radical departure 
from the existing frame of Government. If the Commonwealths were to be treated as sovereignties, as they had been by the Articles, the law would not be an expression of the social fact, and the latter end would not be better than the first. On the other hand, if the Convention treated the Union as a single State, as the fact demanded, their action would not be a revision of the Articles, as had been proposed, but a revolutionary act. It is to the credit of the Convention that it took the course which the occasion demanded, even though illegal, and framed the Constitution for a Federal State. The Convention departed from the provisions of the Articles, which could be amended only by the consent of all the Commonwealths, by declaring that when the work of the Convention had been accepted by nine of the Commonwealths, it would constitute their fundamental law.

It has been held, and with much justice, that as the Convention was a representative body, chosen for the special work of drafting a Constitution, their production might be accepted as the expression of the will of the State without recourse to an endorsement by popular vote. But in American history the convention has seldom assumed that power. However, whether the convention submits the fruit of its labor to the people, or promul-, gates it without this action, does not affect the character of the Constitution as law. The Government does not institute nor constitute itself. That is the work of the State.

It is by means of the Constitution that the State grants to the Government its authority and the instructions for 
its exercise. Thus it is plain that the Constitution is not a compact. Such it could not be between the State and the Government for the sufficient reasons that the Government is organized by the Constitution and also because the Government is but the expression of the social will. One might as well claim that the child is a contracting party at its own birth. The idea that the Constitution was a compact had its origin in the time when the Government and people were looked on as two independent parties. At this time the privileges won by the citizens were regarded as concessions by the ruler, and reforms were treated as mutual agreements between the people on one hand and the king on the other. Indeed, since the king of those days stood for a private rather than a public interest, there was much apparent reason for looking on Constitutions as agreements between the governor and the governed. Also the individualistic conception of society as an agreement between the members, gave the basis for such a conception of the Constitution.

Such an agreement was made by a few passengers in the Mayflower to guard against the dissensions which seemed on the point of breaking out in the little company, but this agreement would scarcely rank as a Constitution framed by a State. It is a relic, as are many of the preambles of the first Commonwealth Constitutions, of the individualistic philosophy which colored the speech of the seventeenth and eighteenth centuries, and some of the writings even yet. Unless the psychological conception of the State is altogether at fault, the Con- 
stitution is willed by the State and is not at all a contract of partnership. Even Rousseau, the apostle of individualism, held to the supremacy of the common will.

The preamble to the Constitution of the United States reads: "We the people of the United States, in order to form a more perfect union, establish justice, insure domestic tranquility, provide for the common defence, promote the general welfare and secure the blessings of liberty to ourselves and our posterity, do ordain and establish this Constitution for the United States of America." This explicitly states that it is the State which gives to Government whatever authority it may possess. The articles of the Constitution provide for all the departments of the Government, in some cases for the composition and duties of the department; in others, as the judicial department, leaving upon Congress the entire work of organization. The Government may not, except by provision of the Constitution, add to the departments, nor to the functions which they are empowered to exercise. For this reason there is not found any place for inherent powers in the Government, since authority is delegated to it by the Constitution. Our Constitution is a model of explicitness in holding the Government strictly responsible for all the authority which it is deputed to exercise.

Much was made in one period of our history of implied powers, but so far as these are present they were delegated as all others. Article $\mathrm{I}$, Sec. 8, contains a clause which empowers Congress "To make all laws which shall be necessary and proper for carrying into execution 
the foregoing powers." In this clause lay the basis of the doctrine of implied powers, the Federalist Party led by Hamilton wishing to give to Congress a wide latitude for legislation under this provision, the Republicans under Jefferson insisting upon limiting the sphere of legislation to what was strictly " necessary." The view which obtained acceptance with the judiciary held that authority for the action must be shown to have been expressly granted, but, this fact being established, the power may be broadly interpreted. This is an additional proof, if any be needed, that the Government has only delegated authority.

The Constitution also provides that officials shall be chosen for brief periods, in order that they may be frequently reminded that they are servants of the people. The fear was prevalent a century ago that the Government would encroach upon the freedom of the individual, and therefore officials were allowed only short terms so that they might not become arrogant in their use of power. It may now be questioned if this idea has not been carried to an extreme and if efficiency in some departments might not be promoted by longer terms for the incumbents. Specially does the consular service suffer through displacement of tried men with the change of party ascendency at Washington. An official is often relegated to private life, or to other official duties, about the time when he has gained the acquaintance with his work, which would make him of value in his position. Specialists are needed in official positions, and they may be had only at the price of premanent employment. 
Some attention has been given here to this phase of the Constitution, because in our country more than in any other has the social fact of the delegation of authority from the State to the Government been put in terms of law. The other social fact which this one illustrates is that the State receives its authority from Jesus Christ and therefore should make such recognition of its divine King as the State, on its part, requires of the Government.

\section{The Government Delegates Authority to Officials,} Municipalities and Corporations.

In order that the Government may perform its functions, it must commission deputies to enforce executive orders and decisions of the courts. Without this, the federal laws would become a dead letter in many communities which are not in sympathy with them. These deputies owe their authority for the performance of their official duty to the Government, not to the State. They are not legally amenable to the people.

Municipalities and corporations receive their authority through charters, which define their functions and privileges. So long as these institutions keep within the provisions of their charter, the Government is under obligation to give them protection. This would seem to place the business corporation in the same relation to the Government, and to the State behind the Government, as is held by the deputy commissioned for a special service. It is commissioned for a special social service. That this view is not accepted by the corporation management is not a sufficient argument against its reasonableness. The 
official sent out by the Government to take the census, or to perform some other duty, is generally recognized as carrying out a public trust. Why should not the corporation, which has its duties and privileges defined in the charter which created it, be considered as performing, likewise, a public service? In both cases social powers are being used, as when a railway company is able to force a right of way through a man's land, by the use of the State authority of eminent domain. Without this social force to carry out the wishes of the company, they could not enter upon the land of any man who was unwilling to grant the privilege. Whenever social powers are used by an individual, or by an institution, for private ends, it is recognized as a criminal proceeding. Is the corporation, or its function, of such a nature as to exempt it from the general rule? Political corruption enters at the point where the official looks on his position as one which may be used for gaining private wealth, without regard for the public weal. Does the corporation management become culpable under like circumstances? If they are only stewards of the social power which they use, this would hold true. In any department of social administration there may be an abuse of the authority granted when the recipient fails to recognize the obligation which he owes. This is not at all an argument for economic socialism, but rather is it a suggestion that if corporations properly realized their function there would be no ground for the socialistic appeal.

Every social function is carried on by delegated authority, since authority can be had in no other way. No 
institution has any inherent powers, or authority. At no point does it appear that this delegation and consequent responsibility is questioned except the authority. which the State receives from Jesus Christ and that which the corporation receives from the Government. Social philosophy suggests a correction in the popular view at these two points. 
THE GENERAL PRINCIPLES GOVERNING THE USE OF AUTHORITY

Through the history of the development and administration of Government, certain principles may be traced which appear to be of general application. In any Government in which the despotic idea is uppermost, no principles need be sought, since, in such case, might is the only right; but in any Government in which the sense of responsibility is present, these principles may be detected.

I. With Every Delegation of Authority, a Law Is Prescribed to Govern Its Exercise.

2. When Authority Is Received, Recognition Should Be Made of the Obligation to the Agency Conferring the Authority.

3. In the Recognition of Authority No Intermediate Agencies Should Be Passed Over.

These principles, which are worked out in each constitutional Government, are equally manifest in the operation of the divine rule. Should the evidence to be presented bear out these statements, it may fairly be concluded that they are universal principles, which in all cases should be followed. It is the philosophical problem of our time to find the unity of all in the diversity of all. Along the line of these principles must that unity be sought. What is demanded is the unity of the divine 
and the human, which will gain complete unity with the conservation of the divine will and human freedom.

The preceding chapter dealt with the four steps in the delegation of authority; from God to Jesus Christ, from Christ to the State, from the State to the Government, and from the Government to the agencies under its control. It is the purpose of this chapter to apply the three principles stated above to each of these four steps in the delegation of authority, to see how far the principles have been realized in practice, and also what is yet to be realized before the social system may be unified through obedience to law. As the last step in the transmission of authority is the one which finds most ready illustration from daily experience, it may afford the best point of entrance on the examination.

I. Are the Three Principles Realized in the Giving of Authority by the Government to Its Deputies and to Chartered Institutions?

There are two ways in which a corporation comes into existence, either by a special grant, or under a general law. Since the former method has been somewhat discredited through the favoritism which may be practiced under it, the latter method is the one in common use. Under the general law, any individual, or individuals, may become a corporation on condition of complying with the law, specifying the business in which they wish to engage, the capital invested, the name to be used, and other particulars which may serve to guard the public interest. Having thus complied with the law laid down 
by the legislature, the corporation, as a political body, is an agency of the Government for carrying out its functions. The corporation having been authorized is not at liberty to change its name, its business, nor to consolidate with any other except by permission of the Government. Should the corporation fail to keep the rules laid down in its charter for its guidance, it is not only the privilege but the duty of the Government to call the corporation to account for its abuse of powers.

The abuse is not infrequently in those who grant the authority as well as in those who use it, since there is just cause for the charge that the legislators are often the agents of the chartered corporations, if not actual members, so that the charters do not guard the public interest. The people of Pennsylvania will not soon forget the Ripper Bill by which the streets of some of her cities were presented to certain corporations for the use of street-car companies, a gift which defrauded the people of many millions of the wealth which had been socially created.

These abuses of the principle, however, do not militate against the principle, since in all cases the Government lays down law, bad or good, for the conduct of these enterprises, and the business is legitimate only as the corporation keeps within the provisions of the law. The first great industrial combination of which we have any record was attempted at Babel without a charter, with the result that the undertaking was stopped and the company disorganized.

The municipality closely resembles the corporation in 
its chartered capacity. It is authorized to levy taxes, to contract debts to a certain amount, and to make improvement, by the provisions of the charter. When it is found necessary to go beyond the stipulations of the charter, application must be made to the legislature for the privilege. Even when the legislature grants the city streets to transportation companies, the municipality has no remedy at law. So closely is the municipality guarded in its use of authority that it is not allowed to void a former contract, even when it is clear that public interests would be profited, provided there are vested interests involved in the old contract.

The officials acting under Government authority receive this authority in a commission, or warrant, which defines their powers and duties and, as long as they observe the conditions of the commission, they act with the whole power of the Government. An accredited representative of the American Government at a foreign station embodies the authority of the American Government in himself. But this does not make it allowable for him to act at his own discretion. There may be critical emergencies when it is necessary for him to act without any direct warrant, since provision for the case had not been made in his letter of instruction, but aside from such unusual instances he is strictly bound by the law which was given to him when empowered to act.

When the official does go beyond his instructions his act is not official, but is that of an unauthorized person. For such action the officer is liable to prosecution. For instance, if a sheriff has a warrant for searching certain 
premises, and should make this the pretext for a general search, he would be liable for such action. The individual takes certain obligations upon him on assuming the office, and must carry them out or resign, if he is true to his assumed obligations. In the days when the Fugitive Slave Law was in force, many sheriffs, who did not agree with the law, refused to serve the writs; but it does not seem that when the official has sworn to uphold the law that he is justified in disregarding its provisions. If he feels conscientious scruples about administering the law, it would seem better that he should not assume the duties of the office. When a position is taken under conditions that are specified and known, it is not open to the incumbent to disregard them. It is in place for the official to tender his resignation if he feels that the work required of him is morally wrong. These illustrations are enough to show that at this point of the delegation of authority, a law is given with it.

In regard to the second principle, that the source of authority should be acknowledged, it is equally evident that it is followed in the cases under discussion. The officials under the Government, the municipalities, and the corporations, all recognize the agency which authorizes their actions. The corporation at once falls back upon the Government for support whenever any third party infringes upon corporation rights. If the courts decide that the acts of the corporation are within the terms of the charter, the corporation may call upon the police powers of the Government to uphold its claim. In the frequent strikes among the employees of the street-car 
companies, the police is called on to keep order on the line. Thus the corporation recognizes the source of its authority. Should the police fail to give the corporation the required protection, the militia is called on to restore order. When one remonstrates with the dealer in liquors about carrying on his trade, he is apt to appeal to the authorization of his business by the Government, as this fact is shown in his license.

The recognition of the authority of the Government by the official is explicitly made in his oath of office and frequently in its administration. Before the political official can enter upon the duties of his office, he must swear to perform his official duties and also to obey the general laws under which these instructions are given. Should he refuse to make this recognition of the agency which authorizes the action, he could not legally enter on any official work. When a representative of our Government goes to another country, he presents his commission declaring his authority, as a basis of making any official communication to the foreign court. Aside from this commission, which acknowledges the authority of the Government of the United States, he is but as any other citizen of the country. It is the acknowledgement of the source of his authority which gives him his dignity.

When a travelling agent comes into a store to sell goods his first announcement is of the name and reputability of the firm which he represents. The agent may not be known at all, but if the company has good standing in the commercial world, its name recommends the agent to the customer. It is therefore a common rule in busi- 
ness, as in political affairs, to acknowledge the source of authority.

The third principle previously stated, that no steps should be passed over in the recognition of authority, has been implicitly followed, except in the case of the Government official. The question raised in regard to the official is whether he should be guided by the law governing the case or by the sentiment of the community. It has been the acceptance of the latter alternative as the rule of official conduct that has caused a practical nullification of law in many communities. The laws in some of the Commonwealths, notably Maine and Kansas, have prohibited the saloon within their jurisdiction. In certain cities the liquor element is sufficiently strong to control the election of the city officials. Now if the magistrate were true to his oath of office, true to the principles that are operative in any efficient Government, he would enforce the existing statutes regardless of the local sentiment. Any other course of action means that the law shall be operative only in those districts where it has the support of the local sentiment, so that each community exercises the privilege of vetoing all legislation which does not suit the neighborhood. This was the principle on which South Carolina nullified the law of Congress in 1832 and forbade its enforcement within the Commonwealth.

The following out of this principle means the subversion of all Government. The Southern statesmen proposed only the sovereignty of each Commonwealth, but this goes much farther, making each neighborhood 
independent. Further, if each city has a right to 'disregard the enactments of the legislature, may not the wards pass upon the city ordinances? There are no limits to this idea of nullification, if once it is admitted as a working principle. The essentially anarchistic idea of reducing all law to a matter of local option needs no comment.

Now this result is a consequence of failing to follow the third principle, which insists on recognizing the agency immediately superior to the one using the authority. The official is a member, or a deputy, of the Government, sworn to perform a certain service; it is not for him to hunt after what the locality wants in the case, since he is not responsible to any authority but that which commissioned him. Failing to enforce the law according to his oath taken on entering the public service, not only makes the official guilty of perjury, but as well endangers the political system of which he is a factor by violating one of the principles which is essential to Government.

It is not an unusual thing in municipal elections for $a^{\prime}$ candidate to appeal for the suffrages of the voters, on the understanding that he will nullify the law. With the exception of this criminal failure of duty on the part of the public officials, the three principles that are to be observed in the delegation of authority are realized in the relation between the Government and the agencies through which it performs its functions.

2. Are the Three Principles Noted, Obeyed in the Giving of Authority by the State to the Government?

The principle that a law is given when authority is 
conferred, finds no clearer demonstration than in the Constitution which the American State lays down for the Government. As has been already noticed, the Government has no inherent powers; all that it has are granted by the State and are specifically catalogued in the Constitution. The framers of the Constitution had in mind the aggressions of the English kings upon popular privileges and it was the intention of the fathers to place every safeguard about individual rights. To this end all the powers not conferred upon the Government by the Constitution were specifically denied to it by that instrument. Nor was the legislative department, which was most feared, left with the legal prohibition only, for the Supreme Court was created to hold the other departments in check. To one who has given the Constitution even a cursory reading, it will need no argument to show that when the State gave authority to its Government, it gave it under strict provisions of law.

The second principle, that the body conferring the authority should be recognized, is also realized. The Constitution is prefaced by the, statement that the authority of the Government rests upon the State, therefore every official who swears to the Constitution, and each one must take the oath, acknowledges the authority of the State which gave the Constitution. There is no question in the United States about the Government recognizing the authority of the people, the chief danger being that the officials may become mere automatons recording some temporary wave of sentiment. The fire of criticism through which the political leader must pass, 
keeps him from forgetting the authority which exalts him and may pull him down. So sensitive are public men to criticism that there has been an attempt, not without success, to silence the criticism of the press by party threats, or the giving of patronage. In recent months the Post Office Department has seen fit to exclude from second-class mail privileges, certain papers which advocate Prohibition or Socialism. Some excuses were given in each case, but they were not reasons. The hope of a good administration of Government lies in discussion of public men and measures and if this can be silenced, in whatever way, the consequences would be such as the patriot could not view with complacency.

When a citizen becomes a candidate for political preferment, he lays down the propositions, called his platform, that, under the Constitution are to guide his official conduct. This platform is framed with the purpose of commending the candidate to the electors, as a man who would render efficient public service, and the voters are left to choose the one of the candidates whose views seem best suited to the social needs. Thus from the beginning of his candidacy till the end of his term of office, the official is seldom lacking some reminder of the fact that the State is the source of Government authority and he is frequently called upon to recognize this fact.

Coming to the last principle, that the immediate source of authority should be recognized, it is to be said that Government should not recognize some more remote authority to the exclusion of the State. It was the defect 
in the theory of the divine right of kings, that the monarch ignored the people in his acknowledgment of authority, thus leaving the way open for a disregard of the social welfare. The Government does not draw its authority immediately from God. Government is the natural working out of the social nature which God made in man. It is a permanent social institution. The authority exercised in Government comes from God through the State. The fact is that when any of these principles stated at the beginning of this chapter are disregarded, it brings about disastrous results. We have before us in the daily press the results recorded where officials disregard their oath of office, leaving the laws without enforcement to suit the people of the local neighborhood. The idea of the Stuarts that they drew their authority directly from God, cost England a century of struggle and the Stuarts a throne.

3. Are the Three Principles Observed in the Delegation of Authority by Jesus Christ to the State?

Since the Bible expressly declares that all authority is given to Christ, it follows that all authority exercised in social affairs must come from Him. Does Christ give law when He confers authority? Some, even Christians, have insisted that Jesus Christ does not rule over the whole life, that part is not under His law. Yet, unless a man is made on the compartment plan, it is not possible to split his life into sections. Life is a unity, not a dualism. A man is not a Christian by sections. Thus when a man argues that there should not be any religion 
in business or politics his error is psychological but no less fatal. If religion is a factor in life at all, it goes through every part of the life. If there is no religion in politics and business, there is none in the life at all. Jesus Christ gives law to the whole life. An individual, or a people, may refuse to obey this law, but it is idle to claim that religion dominates the life, when some part of it is independent of religious control.

Jesus Christ laid down the general principles of law at Sinai, or, more exactly, he stated the law on which society was constructed. The Moral Law is the social constitution of man, not given first at Sinai, but stated at Sinai. It was given when man was created. Some, at least, of the precepts had, through experience or revelation, been known before the announcement by Moses. The acceptance of the Moral Law was clearly stated as the condition on which the Hebrew State might lawfully exercise authority, a condition alike applicable to any State, since the constitution of man has not been abrogated with the lapse of time. The New Testament is also a book of law, stating a deeper significance than had been understood before. The Bible, therefore, is the law which Jesus Christ gives and the authority which he confers upon the State is to be used according to Scriptural directions. It would be an inadequate guide for men if it did not furnish rules for the whole life.

The Hebrew State fulfilled the second principle by acknowiedging the authority of Jesus Christ When the law was read at Sinai to the representatives of the people they declared: "All that the Lord hath said will we do 
and be obedient." This was an explicit recognition of the law giver. They were not able to live up to the law and the repeated instances of national repentance were often accompanied by a renewal of their recognition of the authority of Jehovah. Thus the Hebrews made an effort to keep the second principle involved in good government.

It is at this point that modern States fail to meet the requirement. No modern State has made the recognition of the authority which is in control of social affairs. The failure to follow the principles involved in the delegation of authority has been no less disastrous at this point than at others. In several of the European States the Constitution declares that the monarch rules "by the grace of God," but this is quite another thing than an acknowledgment that the divine authority is recognized in governmental affairs. Such phraseology lays no obligation to make the divine law the rule of official conduct. But, in addition to this defect, such religious feature fails to honor God, since it disregards His express teaching that men much acknowledge God by acknowledging Jesus Christ. This is not a mere matter of words. It is stated: "No man cometh to the Father but by me." "He that honoreth not the Son, honoreth not the Father which sent Him." To pass over Christ in the confession of the source of authority dishonors God, since it disregards his word and act in giving "all authority" to Jesus Christ.

Such conscious omission of the acceptance of Christ is the refusal of the only mediator between God and man. 
The usual reason for ignoring Jesus Christ in the social confession of the source of authority, is that the dominant social influence in the State objects to the name of Jesus while all classes believe in some kind of a God. The God of the Christian is the Father of Jesus Christ and $\mathrm{He}$ can be pleased only by the confession of His Son.

We are not dealing with one who is deceived by verbal forms. God reads the mind of the State as that of the individual, and demands that $\mathrm{He}$ should be honored in His own appointed way. The cosmic philosophy, the unity of law, the teachings of the Bible are in cordial agreement in insisting on the harmonizing of the will of the State with the will which guides the universe.

4. The Principles Involved in the Delegation of Authority Are Realized in the Relation between Essential God and Jesus Christ.

The Father gives law to the Christ and acknowledgment is loyally made of its delegation. "I came not to do mine own will," said Jesus, "but the will of Him that sent me." Many times in the ministry of the Lord does $\mathrm{He}$ make this willing confession that $\mathrm{He}$ came to do the Father's will. Hegel wrote that the State would realize its mission when it would confess: "Lo! I come to do Thy will O God."

This completes the application of the three principles stated at the beginning of this chapter, to the different stages in the delegation of authority. In nearly every stage they are realized in the administration of political authority and wherever they are departed from, social 
damage is the consequence. At one point in particular is failure to be noted, when the State refuses to confess the dependence of the social will upon the will of Jesus Christ, and thus interferes with the cosmic philosophy, of the divine plan. 


\section{THE SOCIAL CONFESSION OF CHRIST}

If a cosmical unity is to be gained, the social spirit must be harmonized with the divine spirit. The social confession of Christ is the means to this end. It would seem that materialistic ideas of the State have somewhat hidden, even from Christians, the proper relationship of the State to the Christ. But when the psychological view of the State has had time to mature in the common mind, so that it may clear the mental atmosphere of the errors in the theories inherited from the individualistic philosophers of the eighteenth century, and the biologists of the nineteenth, we will gain a correct political philosophy and, ultimately, a better political practice. Schlegel teaches in his "Philosophy of History" that every great movement has passed through the stage of theory, and that theory has shaped the later historical events. Admitting that the situation demands that the State should make an acknowledgment of the authority of Christ in the social life, as is required in the individual life, it yet remains to be considered what form this confession should take and where it should be made.

\section{The Form of Confession.}

It may fairly be said that the particular words used in a social confession are not of more importance than in a confession by the individual. The essential thing 
is that it shall accept the law of Christ as the rule of life. It is necessary that the statement shall be free of ambiguities and, as it is to be a standard of official conduct, it should have legal precision. It is not an expression of mere sentiment, not simply the insertion of some name or phrase in the Constitution of Government, but the laying down of a definite ethical standard for legislative, executive, and judicial conduct. As it, of necessity, has this scope, it must be the expression of the social mind, and not that of an individual, or of a number of individuals. It is the expression of a social obligation which is binding on the social life. On one hand, by making this confession honestly, the State comes into a right relation with God; on the other hand, it takes a right position in its relation to the individual citizen. God is so bound in with the universe which $\mathrm{He}$ has made, that no part of the grand cosmic system can be economically operated when God is left out of the plan. Putting Jesus Christ into social life brings about that integration of the State with God, and of social classes with each other which is required " to promote the general welfare."

It will make the discussion at this point more definite to suggest the following adaptation of the preamble to the Constitution of the United States: "We the people of the United States, recognizing God as the source of authority, Jesus Christ as the ruler of the State, and the Bible as the ethical standard for all moral questions in social life, . . . . do ordain and establish this Constitution for the United States of America." 
It is to be carefully noted that not all questions would come directly under the operation of this amendment. Many of the questions with which the different departments of Government have to deal are economic simply, or involve some legal technicality. In dealing with such matters, the question of an ethical standard is of less moment. It is directly concerned with all questions where justice or injustice is at issue. All political questions have a moral element, but it is not always the dominant factor. The ethical standard would have directly come in question in the recent breach of public faith with Cuba. It would also suggest that some other interests are paramount to those of trade in the Philippines. A tariff law would not, so directly, be appealed to a moral standard.

The application of this amendment would require no change whatever in the form, or the methods, of governing. It would not make any change in the class of cases which would come before the legislature, or the courts. It is concerned alone with the ethical standard which shall be applied to those cases. If any one holds that the present standard is Christian, he need expect no change at all, but one who considers the general disregard of the Sabbath, the licensing of different forms of vice, will scarcely draw such a conclusion. As a matter of fact, every individual, and every institution, has an ethical standard and it is only a question of what that standard shall be. Each one may form his own judgment as to what ethical standard is operative in governmental affairs, but he will not doubt that one exists. 
Whether chosen by intention or not, it is always in evidence. The suggestion here is that the Bible be taken as that standard. No change is proposed in political method. It would seem that every man who believed in taking the Bible as the standard of his own life, should advocate the acceptance by the State of the same standard.

Nor would it, as some have hastily concluded, interfere with the opinions that men may hold on religious questions. This fact is evident when one takes time to consider the kind of cases which come before the courts. Government does not deal with what men think, but with what they do. Why should a change in ethical standard affect this matter? Or, as this book is written specially for Christians, why should Christians fear to be judged by the Bible standard in the courts? Why should the testing of legislative enactment by the teachings of Christ, endanger individual freedom? An objection might be raised at this point by those who do not believe in the Bible, but it is difficult to see the ground on which a believer in the teachings of Jesus would enter a protest. It would seem that Christians should be at one in this matter. Why should the Bible standard endanger freedom, more than a standard of materialistic ethics, or some other? Men are not tried for their thoughts under our system of Government and this freedom which we have is due to the Christianity which should be recognized. It was the coming of Jesus which made freedom of thought and action possible; on this account it can scarcely be seriously claimed that to take the ethics of 
Jesus as the basis of governmental action would destroy the very thing which this teaching made possible, individual freedom.

There is no provision under our system of government for bringing a man into court on account of his theological opinions, or his church preferences. The writer, who is a descendant of the Covenanters who were hunted to the death for their opinion's sake, would be the last to propose a reinstatement of the inquisition for opinion. It is the surest guard against such return, to take the ethics of Jesus as the standard of social conduct. The man who has any reason to fear that his business interests, the title by which he holds his property, his freedom of speech, would be disturbed by the acceptance of the law of Christ as the rule of life, has good reason to question the methods of his business and the matter of his speech. It would seem that every Christian, indeed every honest man, should welcome such a standard in our legislatures and our courts.

Government is continually extending its functions and this process is likely to continue, as it is becoming more necessary to guard individual interests from the encroachment of the great industrial combinations. Government function is also being extended in dealing with the dependent and defective classes of the population. If one will compare the range of subjects with which the legislator deals, with those with which he dealt a century ago, it will be seen that the character of Government is of growing concern to the individual. If the State becomes Christian through confessing the Christ, then will 
the Government, with other social institutions, be permeated by the same influence, to the advantage of the individual. Some standard of action the State has, and must have. Would it not be to the advantage of all good citizens to make the State avowedly Christian?

The proposed amendment falls naturally into two divisions ; the first giving honor to God, the second concerning the welfare of men. The first obligation, the State owes to the rightful ruler of this, and every other, nation; the second to its citizens and other States. There is an old and well established proposition that "Man's chief end is to glorify God, and to enjoy him forever." That is the proposition which this amendment elucidates and applies. In the general scramble for wealth, and our conquest by materialistic views, it might be well to recall that, in the eternal view of things, spirit dominates.

There was a great trading people long ago whose ships cruised in every known sea and their merchant flag floated in every port. They gained their celebrity from gathering the little mussels from the sea and making from them the Tyrian dye, and when the home supply was exhausted they sent out their trading companies to procure the raw material and extend their trade. The Phoenicians have been called the "Yankees of the East" and in material gains they led the world. Yet beyond a few inscriptions we know nothing of their literature and, excepting the genius of Hannibal, there is scarce a Phoenician name which lives in history. A people whose interest centers in trade does not make permanent contributions to history; but those that contribute to spiritual 
growth leave an inheritance which neither time nor change consigns to oblivion.

No favorable balance of trade, nor output of manufactured goods, can balance the social account with an offended God. "Kiss ye the Son lest ye perish from the way," even though factories multiply and railroads increase their tonnage. While the argument in these pages turns, for the most part, on the social benefits to be gained by the social confession of the Christ, since that phase of the subject appeals most forcibly to men, yet it must not be forgotten that the glory of God is not of less account. The question which confronts any people with such opportunities as we possess, is whether they should be willing to accept for themselves the wondrous benefits of the Saviour's death, while refusing to Him the honor which is His due.

\section{The Place of Acknowledgment.}

Neither the form, nor the place of acknowledgment of the authority of Christ is of great account, provided that certain conditions are satisfied. This political confession of faith should be an adequate statement of the kingly rights of the Christ over the State, and it should be so formulated and placed as to give legal sanction to the Bible as the ultimate standard for the settlement of moral questions arising in the sphere of Government. It is to be a standard for the legislative, executive, and judicial departments in the determination of such questions. So far as the matter of place is concerned, this confession might be made to stand by itself as an act 
of the State, superior to the Constitution of Government which we have at present and to which the Constitution and all subsidiary laws would have to conform. The acknowledgment should be placed where the will of the State finds direct expression. The Constitution fulfills this condition. The acknowledgment is not an act of Government, but of the State, and the Constitution is the only law which, in our political method, is made by the State. The social mind does find expression through the measures on the statute book, but indirectly through the action of representatives. The Constitution, our supreme law, is made by the people. It is a change in social mind, as well as in law, that is sought, therefore the act should be the expression of the social mind. The statutes of Congress stand in the name of Congress and are enacted by authority of Congress. The Constitution stands in the name of the people. Since it is the purpose to make the Bible the legal standard of political action on moral issues, the Constitution, which is the supreme law for all departments and all gradations of the Government, would answer this purpose.

It would not have the same effect to place such Christian features in the Commonwealth Constitutions, even in all of them. They are only local in jurisdiction and deal only with local questions; but in the national Constitution the provision would cover not only all moral questions arising under the Federal jurisdiction, but as well those within the Commonwealths, since the Federal Constitution is a part of each Commonwealth Constitution. The Federal Constitution is the political criterion. 
The Constitution is a proper place since it could be secured in that document only as the result of an earnest, popular demand. The pertinent question is sometimes asked, "Of what avail to put such a statement into fundamental law, or law of any grade, unless it is supported by the life behind the law? Certainly in this instance it would have little value. It does not have much meaning for the unbeliever to confess Christ, while he remains in unbelief; nor would a similar occurrence in the social life have great value. It is true that law has a considerable influence on life, and the effect that a high ethical standard of law would have upon the popular ethics is an excellent reason for insisting on the acceptance of the Bible as a standard of civic law. That is an educational force the influence of which is sorely needed in our social life. But as a matter of fact, there must be a change in the social mind, a transformation in the social life, before there can come this reformation in our political institutions.

There are but two ways in which the recognition of the authority of Jesus Christ and of his law may be secured by the State. It is possible that in some great social revolution the need for such a change would appear so pressing that it would be brought about without regard for legal forms. This method would be taken only when the State had been so profoundly moved that the social demand set aside all constitutional methods, a situation for which history affords few parallels. President Lincoln, under the pressure of military necessity, set aside legal provisions in issuing the Emancipation Proclama- 
tion and it is quite possible that the liquor traffic may receive its legal quietus under some such stress of circumstances. The Reformations in Germany and Scotland were marked by popular uprisings, but other causes than religious fervor entered, to some extent, into each movement. The acceptance of the law of Jesus as the rule of the social life must face the opposition of every vicious influence in society, a combination which no other movement has ever had to meet. If nations are "born in a day," such a moral victory may be in the divine plan.

The other method of winning the acknowledgment of the authority of the Christ is through the legal methods provided in the Constitution. In such case the measure, following the usual course, would have to be sanctioned by Congress, then ratified by the legislatures in three-fourths of the Commonwealths. History has shown that such concurrence of different sections and classes is not easily gained, indeed, the only amendments made to the Constitution in a century were the outcome of a terrible war. Professor Burgess takes the ground that the Constitution has put such barriers in the way of its own amendment that only such a crisis as a war produces will make an amendment possible. However that may be, it is clear that any amendment must have due consideration, before a sufficient sentiment is created to give it the force of law. In neither of the ways suggested is there a possibility of putting this proposition into the Constitution without a social regeneration of the people. The people do not want such a change now 
and it will be only when the social mind has been brought to see its necessity that it can be secured. Motives of hypocrisy will never lead to the social enthronement of Jesus. In regard to the question of how the social confession of Jesus Christ shall be made, history affords scant data, and prophecy is silent; but the fact is made sure by the promise of God.

It is also objected that this could not be put into law until the people wanted it, and that then it would not be needed as it would be the rule of the social life without any enactment. This has an element of truth, but in its application would condemn our whole system of law. Laws are not made for the obedient, but for the lawless class. We have laws against burglary, yet public sentiment is strong against burglary. There are few forgers in the community, yet there are severe penalties for signing the name of another to a check. We would need the proposed measure, for the benefit of citizens. even though the dominant influence in the social life were Christian. So much for that phase of the amendment in which the interests of citizens are concerned.

As a last reason, though not the least, this amendment should be in the Constitution because the State should confess its King. This does not mean king of a part of life, with the whole field of public affairs independent of his control. Jesus Christ is King of the whole of life, and in the Constitution, which declares itself the supreme law of the land, that fact should be acknowledged. "For them that honor me I will honor, and they thax despise me shall be lightly esteemed." 


\section{The Value of the Amendment.}

No plea will be more effective with the Christian than this, it honors Jesus. "Though he was rich, yet for your sakes he became poor, that ye through his poverty might be rich." There is no gift, individual or social, that does not come through him. Is it a great thing for him to ask that his teachings be taken as the rule of public and private life? It is sometimes said that if the appeal is taken to the Bible on moral questions, it still involves the difficulty of a double ethical standard, since the Old Testament teaches a different code of ethics than the New. If that were true would not Jesus have known it better than our modern critics? He explicitly declares that $\mathrm{He}$ "came not to destroy the law but to fulfill." "Till heaven and earth pass, one jot or one tittle shall in no wise pass from the law, till all be fulfilled." Yet these sayings of Jesus are taken from the chapter, Matthew fifth, which critics cite as an evidence that the teachings of Jesus are not in accord with the Mosaic law. With all due regard for the opinions of those who find the divergence between the teachings of Jesus and the Ten Commandments, one is inclined to think that he who made the law knew its meaning better than does the critic. That some of the minor provisions of the laws of Moses, given to Israel on account of their peculiar situation, were allowed to lapse with the change of conditions, is doubtless true. But Jesus in his teaching only brings out the deeper significance of the Ten Commandments. He does not annul them. The Bible is a unit in its teachings. 
Few peoples have greater reason for gratitude to Jesus Christ than has the American nation. When this country was discovered by Columbus, Europe was feeling the first throbs of the Reformation. Had settlement in the New World been made at that time, under royal patronage, the early colonies would have been influenced by the reactionary Catholic party of Europe. But God had planned otherwise. In 1492, Spain was ending a contest with the Moors which had tried the Spanish power, and during the next century Philip of Spain, feeling himself the special protector of the Catholic Church and the inquisition, championed the cause of the Pope against the rebellious subjects in the Netherlands. During eighty years the contest went on, demanding its full complement of Spanish energy and treasure, and when the struggle ended in the independence of the Dutch Republic, Spain had lost her power and her opportunity, such an opportunity as comes only once to a nation.

During the century succeeding the discovery of America, France had no energy to spare for colonization. In the earlier part, the French king was hurrying his men and means over the Alps to make good his shadowy claims, against Spain and the Empire, to thrones in Italy, while the last half of the century witnessed the distraction of the religious wars which rent France into factions. While the lands of America were inviting settlers, the Guises and the Bourbons were drenching the fields of France with blood. So was Europe kept from taking possession of the New World until the Reformation had done its work, and when the settlers 
came at last, they were refugees, seeking the freedom in the wilderness which had been denied on their hearth stones. To get the true perspective of the settlement of America, one must know the history of Europe during three centuries, and the more this history is studied will the gratitude increase to that God that guarded the embryonic nation. To our shores came the Pilgrim, the Puritan, the Huguenot, and the Covenanter, sifted by despotic hands from the peoples of Europe to plant in the virgin soil of the American forest.

It is true, though often forgotten, that the high religious sentiment was, for the most part, north of the Hudson. The South was largely settled by an aristocracy of English gentlemen, resting upon a larger population of indentured servants and men whom the press-gang had swept from the streets of London. In our adulation of the early settlers, it may not be left entirely out of mind that the Southern Colonies were, for years, a Botany Bay, for the English police courts. Yet the Puritans north of the Hudson, out of proportion to their numbers, swayed the sentiment of the Colonies.

While other peoples have been hampered by institutions which have outlived their usefulness, we have had a mobility which presented few restrictions. While it is true that we have no long period of history to sustain us by its memories, we have no inglorious record to forget. Isolated from all competitors by the seas, which have, till this time, made us free from the supposed need of standing armies, whose maintenance crushes the peasantry of modern Europe and even of England to the 
subsistence point, we have been left free to develop without these disastrous handicaps. The same seas which insure us freedom from foreign invasion, furnish the cheapest highway for communication with the markets of the world. Untold wealth exists in our national resources and it is a gift to the American people. Shall this wealth be used to win freedom for men and to lead the world to a higher civilization, or shall the material forces, the wonder of the world, crush the spiritual to the earth? Press these material forces into the service of humanity, make the chief end social well-being instead of money dividends, and God would be manifested to men in a way never before realized. This is what it means to make the teachings of Jesus the law of the social life. I am aware of the claim that religion has no rightful place in the market, but without the influence of religion there would be no markets commanding a world traffic. It is religion that guards our lines of railway and steamship traffic, not the police nor the navies of the world. It is not armed force which has lifted the world into the measure of light which it owns; it is not rifles which keep it there. These methods which the rule of Jesus would banish are the parasitic growths of the barbaric ages.

2. It Would Give a Proper Ethical Standard for the Decision of Moral Questions.

We are often informed that the teachings of Jesus are not applicable to our conditions; but certainly conditions were not more favorable when Jesus walked the 
roads of Galilee. Yet he insisted upon their immediate application to social conduct. He did not give us specific rules of conduct, since these would have become obsolete in the course of events, but he laid down principles which never grow antiquated. The disciples considered his teachings practical then, and tried to incorporate them in their lives.

To be guided by "the common consensus of practical judgments," as some advise, means the surrendering of any social ideal. The leader of thought must be in advance of the common judgment of men, else he is not a leader. If a "common consensus" is to be the ethical standard, stagnation is the moral future of society. 3. It Guards the Freedom of the Citizen.

While this is one of the chief ends of the proposed amendment, it is at this very point that objection is usually raised. History has shown that the individual may not trust the monarch to give him the conditions of freedom, nor may he place his confidence in aristocratic rule. Scarcely safer are his interests in the power of the crowd. Polybius taught long ago that it was, the tendency of popular rule to become mob rule and the evidences which support that view are not wanting. In any difference which arises between the individual and the State, the will of the State is a prejudiced party in the case. If a fair judgment is to be rendered, it must be through the appeal to an unprejudiced code of law.

This unprejudiced umpire is the law of Christ which works no injustice. It may be said that even though 
the law of Christ were the legal standard, it might be so interpreted as not to meet the end in view. Doubtless this is possible, but the weaker party would certainly be in better case when appeal is made to the teachings of Jesus, than when made to any other rule. Better surely is a good rule even though warped in its interpretation, than a poor rule used in like fashion. It is hard to see why any Christian, or any honest man, should fear that the applications of the teachings of Jesus would restrict his freedom, since it is through Jesus that freedom comes. Whatever may be true of the unbeliever, the Christian should not fear the appeal to the teachings of the Master.

\section{It Would Win the Confidence of Other Nations.}

The reason why fortresses bristle along the frontiers of the nations, that spies are sent to foreign courts, that every meeting of the kings is jealously observed, is because there is no confidence of one State in another. Nor has national conduct been such as to warrant confidence. The laws between nations are seldom observed when the nation which suffers the wrong is not able to back its claim by force. If the nations of Europe would each adopt the teachings of Christ as the rule of political life, there would follow immediate disarmament. This is said with full knowledge of the fact that ministers of the teachings of Jesus are not less ready than others in their justification of aggressive wars, but it is to be expected that the social regeneration, which must precede the acceptance of the rule of the Christ, will have its 
influence upon these who have misread the Sermon on the Mount.

Armies and navies are mainly the tribute which the nations are paying for the real, or fancied, reasons which they have given for distrust. English statesmen argue that ships enough should be constructed for their navy that they may be able to fight with all their neighbors at once, which indicates that there is something radically dishonest about England, or the neighbors which she has. Some of the American wise men have also been arguing that the only safety of the United States is to build a navy large enough to fight with all Europe, which suggests that some one has been cheating in the game the nations play. It may be allowable to suggest that if the United States had kept faith with Cuba and the Philippines, which we hope it will even yet do, it would have done more to guard our coasts than all the battle ships in the navy. For the present we seem to have forfeited the confidence of the nations.

There are no real friendships between the Governments of the world. One helps another when it has a commercial ax to grind, but it turns its back upon it when a better alliance offers. This utter lack of faith in international friendships is wasting money and men, making disastrous inroads on the scanty earnings of the poor, and the wealth of the rich. Let any people profess to take the teachings of Jesus as the rule of life, giving proof of sincerity and it might disband its armies, using its vessels of war to give outings to the children. War is not the greatest curse that afflicts mankind, but none 
has less excuse. Let us honor the name of Jesus and His law and the nations will have no need to distrust the "Republic of the West."

5. It Would Give to Us a Harmonious System of Law.

Human legislation is out of joint with the divine, since it is made with little consideration of its agreement with the principles of the Bible. To most legislators it might cause a smile, if one were to suggest that the Sermon on the Mount had any connection with practical politics. Yet if Christ gives law to the world can it be practical to follow any other standard? Unity is the end of life; it is the end of law. It can not be gained at any human level, since no human standard can suit all men equally, nor will God bring his law to that criterion. The social law must be brought into harmony with the divine law. When the social life and law is linked with the divine by human choice, the social system will be "fitly framed together" and joined to the throne of God. 


\section{WHAT CONSTITUTES A CHRISTIAN STATE}

The purpose of this chapter is not simply an academic discussion of the Christian State as an idea. It is to determine, from a consideration of social facts, whether the United States may properly be called a Christian State. To the mind of many this discussion will seem unnecessary since, in common speech, not only the United States, but most of the States of Europe, would be classed as Christian. Differences of opinion exist on this question, partly through the lack, or the possession, of the knowledge of social facts, partly through varied interpretations of the facts when known. But mainly are the different conclusions due to the failure to agree as to the meaning of the term Christian. The subject is taken up with the hope that a common interpretation of facts, and a common agreement on the meaning of terms may be reached, in order that a common conclusion may be drawn at the close of the discussion.

An individual, or an institution, deserves the name of "Christian" when Jesus Christ is accepted and His law made the rule of individual, or institutional, life. Nothing less than this fulfills the conditions which Jesus laid down for His followers. The choice of Jesus Christ as the ruler of the life is consciously made by the Christian. The child in the Christian home may imbibe the teachings of Christ; with the years of responsibility 
will come the necessity to make conscious choice of the Christ as Lord. One does not become a Christian by accepting certain maxims of conduct, nor does man, or State, become Christian simply by being surrounded by a nominal Christian civilization. The civilization which has been attained is doubtless due to the influences flowing from the life and death of Christ, but it does not make one a Christian to have shared in those benefits. Many a man who denies the Christ that made the free offer of himself for the redemption of the individual and the social life, has done that much.

The States usually called Christian are those who have benefitted most by the work of Jesus Christ. They are more Christian than Mohammedan, or Confucian. So much is clear to every observer. But are they more Christian than infidel? By the definition offered, the State can become Christian only as it accepts Jesus Christ as the Lord of the social life. Has the United States done so much? Has any other State? When we apply the same test to the social life as to the individual, it does not seem that there should be any great divergence among Christians as to the answer given. In a recent study, "Political Theories," the author, Professor Dunning, passes lightly over the teachings of Jesus with the statement that his doctrines were essentially unpolitical. It is quite true that Jesus gave no specific instructions to his disciples on the political questions of the day, for the very evident reason that it was not possible for a resident of Judea, where the work of Jesus was done, to share in Roman administration. 
Another fact should be kept in mind as accounting for the alleged unpolitical character of the teachings of Jesus. The functions of the Roman Government, at least so far as a province like Judea was concerned, were limited to collecting taxes and putting down insurrections. They did not provide for the poor unless for the rabble at Rome, they had neither schools nor asylums. The taxes were farmed to the highest bidder as in Turkey to-day. At the time when Jesus met the problems of his followers, the care of the weak and the equalization of social burdens formed no part of Caesar's duties. Yet all these matters are dealt with by Government at the present time; all these matters were dealt with in the teachings of Jesus. If they were unpolitical then, they are political now. The Jews spoke the truth when in their passion they said to Pilate: "If thou let this man go, thou art not Caesar's friend." The enthronement of Christ in the hearts of men meant the dethronement of Caesar and all his kind. The realization of the teachings of Jesus meant political revolution then, would mean it now. The classes to which Jesus directed individual care are now the wards of the State. The questions with which $\mathrm{He}$ dealt are frequently met in the sphere of political control and the principles He taught afford the answer.

If Jesus had lived in a country and in a time when the people had political questions to settle which were of moral importance, is it not probable that $\mathrm{He}$ would have given an answer as readily as on other concerns of life? It is true that $\mathrm{He}$ did not advocate revolu- 
tion against the Roman as His countrymen desired, but His refusal to do this was a political act, based on political principles. The only writing of the New Testament which was directed to a locality where the citizen could share in the duties of government, was the letter to the Romans, and it contains a chapter on the character of Government. This letter states that all rightful authority is from God, and that the true principle of administration is love.

Jesus taught that the Kingdom of God is not to be altogether postponed till a future life, but that it is a present social fact. Slowly it is being realized on earth through the working of the Holy Spirit. When the Kingdom has so far entered any State that the will of Christ is consciously chosen as the law of the social life, then the State is Christian. There is room for debate in deciding when this condition has been met, but there is no other adequate test. This is the test which I would apply to our social order in seeking an answer to the question, "Is this a Christian State?

There are two ways in which we may judge the character of the State: by its profession, and by its practice. Individual acts define the individual character; social acts define the social character. If the fruit is good. so is the root. If the social life is Christian, it will appear in its outcome. These are the tests by practice, and unless the profession corresponds, it will have little value. There are three methods of social expression: that through the individual lives of the citizens, through institutions, and through the civil law. 


\section{The Individual Life.}

The individual life is in some degree an exponent of the social character. Not that the social life has full expression through one individual, or even through all the individuals in the society. Yet it is a common, and not altogether false idea, that we can judge of a neighborhood, or country, by the resident whom we meet. We judge by the speed and accuracy of his work as to the industrial efficiency of the community; from the variety of his knowledge we estimate the worth of the school system; from his conduct we draw a conclusion as to the moral influence of the environment. It is, then, fair to conclude that we may be aided in deciding our question as to the Christianity of the State by the study of the individual citizen.

Is the average citizen of the United States a Christian? By this is not meant a nominal Christian, but one who fills the conditions of the definition by taking the Christ as his Lord and Christ's teachings as his law. This is a hard question to settle finally. It can not be determined by the Church membership, since some of these would not meet the requirements. The idea prevails outside the Church membership that the teachings of Jesus, however good they may be, are not practical in their application to present conditions, and this conclusion is not seldom found among Church members. Should the definition of the Christian be wide enough to include such persons? Should one be classed as a Christian who refuses to accept the rules of life which Jesus taught? There are various interpretations put on 
the teachings of Jesus by Christians, according to their knowledge of Him, but it does not seem that one who declines to accept these teachings as a basis for his theory of ethics, deserves to be called a Christian. This is the case with a majority of the people outside the Church, and a respectable minority inside.

It is for this reason that a conclusion can scarcely be arrived at in regard to the attitude of the average man in this country toward Jesus Christ, at least one which would satisfy all parties. The writer believes that the social facts prove that the dominant social influence is unchristian. The weight of evidence also seems to show that though the average citizen is influenced by Christianity, he is not a Christian. Statistics which have been gathered with some care, show that not more than ten per cent. of the young men in the country have any vital connection with the Church. The percentage is much larger among some other classes, but it does not total half the population. One will usually find, unless he lives in an exceptional community, that when he tabulates the Christian members of the city, or town, the majority is on the wrong side. The chief value of this reference to individual character lies in the fact that it suggests to each reader the possibility of drawing upon the social facts in his neighborhood as a guide in making up his mind as to the social character. If one has been a close observer of city and country life, if he has also had an acquaintance with the different sections of the country, his opinion would deserve consideration. 
If observance of the Sabbath is taken as a test of the Christianity of the individual, the crowded cars and boats on their way to pleasure resorts, while the preacher talks to empty pews, afford a convincing item of evidence. More people might be found in a single beer garden on the Sabbath, than in all the churches of the ward. These are some of the evidences which are discouragingly abundant in most localities.

Social Institutions.

Social institutions rise through the objectifying of the social spirit and therefore reflect the character of the social life. This the individual does not do completely, since each has an individuality of his own in addition to the social element expressed through him. It is, therefore, from social institutions that we gain the best notion of the character of the State. If these are definitely Christian, it is fair to conclude that the spirit which acts through them has a like character; if they fail to meet the requirement, an opposite verdict must be given.

\section{The Church.}

It is to the Church that one would naturally look to find the highest expression of Christian life. In the Church are gathered nearly, if not quite, all of those who have consciously taken Christ as Lord. The Church, by profession, has taken this stand. It sends its messengers through the world to call on individuals and institutions to accept the teachings of Jesus. That the work of the 
Church is done in an indifferent manner must be admitted by its best friends, yet it is through the Church, the united followers of the Christ, that the Spirit of God is to be infused into the șocial spirit. While the Church is a social institution, an expression of the functions of the State, yet through the Church is the State to gain the transfigured life. The Church life is to react into the life of the State, changing the latter into its likeness.

This function of the Church is illustrated in the purpose of the civil law. In idea, if not in fact, law is educative. It is a product of the community and yet it does not serve its purpose unless it provides for advancing social order and freedom. Thus while the Church is an expression of the social life, it has for its end the changing of the social life. There is a strong tendency in certain quarters to insist on a dualism between the life of the Church and that of other institutions. But as a matter of fact the character of the Church will not differ remotely from that of other institutions in the same society. The reason is clear. Some of the same people are in the Church and in the factory, so that the conduct of the two institutions can not be diametrically opposed to each other. The preponderance of a different element in the Church and the factory, may, however, make one dominantly Christian while the other is not. But the two are apt to shade into one another in character. Where two institutions have the same membership, they must have the same character.

Men can not lead a dual life. They can not be Chris- 
tians in the Church and something else in business. If they are trying to follow out such a plan the strong probability is that they are not Christians at all. Yet it is possible for the Christian, who holds a controlling position in the Church to have a subordinate one in the corporation, where another force than Christianity is in control. The practical conclusion is that while the Church can have, and usually has, a more perfect ethical standard than the other social institutions of the neighborhood, it is still true that the Church can rise only as it lifts the others with it. There is a unity in life, which strongly inclines all contemporary institutions toward a common standard. Yet the different social functions which dominate in the different institutions draw about each its own class of men, so that while there is a common likeness, each institution has an individuality of its own.

The Church, as a whole, is Christian. It has unworthy members, it does unworthy things at times, but its dominant idea is obedience to Jesus Christ. It is not demanded by the Church, nor by the Christ, that a perfect life shall be achieved, in order that the term of Christian may be earned. If the demand took such form it would exclude all individuals, all institutions. It means the sincere acceptance of Jesus Christ as the Lord of the life. This much deserves to be said to prevent a misunderstanding of what is meant. It should be the aim of every lover of Jesus and of humanity, that all social institutions should be brought into loyal obedience to the authority of the Lord. This is the commission of the Master and the mission of each disciple. 


\section{The School.}

Education is one of the most important functions in the State, properly understood, the most important. The school is only one of the agencies in the work of education, but the school differs from the other agencies employed, in that it has no other function. The farm and the factory train the child in industrial methods, the Church furnishes him educational ideals, the Government trains him in civil order, the family gives to him the initial steps in all these directions. The school is the result of a social demand for an agency which shall devote itself to education solely, with teachers trained for the work. As both the individual and the State are spirit, in the final analysis the development of spirit is the main aim of both the individual and the State.

Education means the development of spirit. This should be the aim of every teacher, whether in the Church or the home, the school or the pressroom. The meaning of education is to lead out the life. The imparting of information is an element of education, but must not be mistaken for it. Information does not of necessity enlarge the life. A student may acquire an accurate knowledge of a language, he may be able to master difficult problems in mathematics, and have no broader sympathies than before these subjects were studied. $\mathrm{He}$ is informed; not educated. It has been charged that the atmosphere of a University is too frequently heedless of the life movements going on in the world about it. That can have no meaning other than this: it is imparting information instead of educating. 
When a convict was being enrolled at Sing Sing prison he said to his jailor: "I speak seven languages." The jailor answered that they had only one there, and but little of that. The man had been informed, 'but not educated. Men whose lives are "led out" do not go to prison. Our prisons are not filled, for the most part, with the ignorant class. There are the men who know how to forge a name, to raise a check, to falsify an account. The untrained criminal may steal a horse, or run off with your purse, but he is not capable of the fine art which marks the accomplished rascal.

The ruffian who snatches your watch, with training in the schools might loot a bank. It is possible to cram a student with all the curriculum from the multiplication table to metaphysics, and leave him with scarcely wider vision of the world's needs, of the struggling life about him. Indeed, it may even give him a pride of knowledge which makes him more unsocial than the man who digs by the roadside and murders his English. At some time we may outlive the cramming process which is frequently certificated by a degree as an education. It may be too soon to tell what changes in studies, and specially in method, are needed to make our educational institutions what they ought to be, in order that they may have their proper influence upon the life which they develop.

Education is not putting something in, unless as the pump is primed to draw something out. The mind is not to be filled, but expanded. Jesus was the great teacher, and $\mathrm{He}$ drew His lessons from all that which $\mathrm{He}$ saw about Him. He felt with the ravens and the sparrows; 
He sympathized with the sower; He gloried in the lilies of the field. His life went out to all these things, and, more than to these, it opened new visions to the needy who crowded His steps. Emerson said somewhere, "Nature hath no secrets from the sympathetic mind." It is a closed book to the man who brings only information in his quest. Jesus said: "He that saveth his life shall lose it." That doctrine is quite as applicable in the school as in the Church. It is excellent pedagogical doctrine. The man who saves his life is not led out, not educated. Jesus taught His disciples that they should become universal. Their lives were to be broad enough to touch every individual, and class, and race. He does not cram their lives, but $\mathrm{He}$ draws them out till the simple peasant sees visions which philosophers are denied. The Jews said of the Teacher: "How hath this man letters, having never learned?" Such was the judgment of the schools on Him who knew all things, though $\mathrm{He}$ did not patter over the dry matter of the classrooms of the day. It is the Spirit which leads men out into the broader life, and the Bible is the text-book which $\mathrm{He}$ uses. Whatever of expansive influence there may be in other teachers and texts has its origin in this Teacher and this text. Cram into a mind all possible knowlege, leave it untouched by this vital influence, and the life will remain narrow and unprofitable. This is a fact which few thoughtful Christians will question. It is not intended to enter any charge against the present curriculum of the schools by this writing, though such an indictment might possibly be supported by a fair amount of evidence. What is 
asserted is that these studies by themselves will not furnish an education.

Christianity is the expansive influence in life, so far as such influence is present. We do not often try to teach science without a text, or history without a reference book. The Bible is the text of Christianity. It is the book beyond all others which leads out the life into broader endeavor. That is to say, the Bible is the best book for educating the life. By what right may it be excluded from the curriculum of the school which has education for its sole function? The situation calls for something more than a cursory reading of a few verses in the morning. School books are not studied in that way. The Bible deserves at least the place which it once held in the schools, when it furnished the reading lesson for the child.

We would be reluctant to allow the name of scientific to a school which had no place for a scientific text; we can not be less reluctant to apply the name of Christian to the school which does not include the accredited text of Christianity as one of the studies in its curriculum. Not only does the exclusion of the Bible preclude a rounded development of the student, but it fails to keep before the mind of student and teacher the very principles on which a real education rests, and according to which it must advance. This demand for the Bible as a reading book in the classes, at the very time when it is having to contest the place of a morning exercise, may seem extreme. But does the situation admit of anything less? Education means the leading out of life; the Bible is 
the book that shows the way. Would any Christian educator question either of these propositions? Does not the conclusion follow that the Bible should have a place in the curriculum of the school?

It has not that place. In many localities it is not allowed to be read, even without comment. Has the school any sufficient claim to the name of Christian under such conditions? It is a fact of large significance that the teacher is apt to be a Christian; it is also true that he may bring his Christianity to bear in many ways upon the lives which he is training. But no one would claim successfully that the school of the present day aims to teach the life of Jesus as truly as that of Washington. Why should it not?

It is said, though most frequently contrary to the evidence, that there are other places where the child may learn these things, if they are necessary. But admitting this for the sake of argument, it has no particular bearing on the case. It is the function of the school to educate, and if it does not provide conditions for developing a rounded life, it fails of its chief end.

In spite of the fact that instruction in the Bible was the chief reason for the establishing of the common school after the Reformation; in spite of the fact that most of the teachers in the primary schools are Christian, it seems necessary to conclude that since the teaching of the Bible is not allowed in the schools, they are not taking the teachings of Jesus as the law of life. If this is the law of school life, why should it not be taught? If it is not taken as the rule of life, the school is not Christian. 
This defect is much more marked in the higher grades of school work. In our Universities Jesus is not accepted as more authoritative in His teachings than Kant. The Lord is treated as one among other philosophers. As an evidence that this is a common indictment against such institutions, one need only refer to the fact that the different Christian Churches have thought it necessary to establish denominational schools in which a rounded education shall be given. In appliances and opportunities for research they are usually inferior to the institutions which can boast of larger support, but this defect in equipment is endured by many students rather than accept an education on a materialistic basis. If our Commonwealth Universities were Christian, the denominational school would have difficulty in justifying its existence.

\section{The Saloon.}

The Church and the school represent the best elements in the social spirit. Yet if we are to pass judgment upon the character of the social spirit, it is necessary to include the extremes of good and bad in the survey. The saloon may fairly be classed as a modern social institution, since it evidently expresses one phase of the social life. It is not one which arises from the attempt of men to satisfy legitimate wants, but is demanded by a perverted sense. The patron of the saloon insists that it is necessary to the expression of his life, and until he is convinced to the contrary the saloon defines his character. So while the saloon holds the most prominent positions on our 
streets, must it be treated as an expression of social character.

The Church and the school are natural antagonists of the saloon. This is legally recognized by the provision in the laws of many localities that the saloon may not be licensed within a certain distance of the school or the Church. This amounts to an admission that they do not represent the same social interests. They stand for different phases of life, yet each meets a social demand.

No attempt will be made in this place to show the evil effects of the saloon and its adjuncts, the brothel and the gambling room, upon society. The facts are before the world, and each man must make up his own decision from them, but it is the conviction of the writer that the influence of the saloon is more pernicious than any other in modern life. Its alleged social features give it the greater possibilities for social damage.

Yet there is probably no other institution which wields greater social power than the saloon. The political parties do not dare to antagonize the liquor power. The candidate may be doubtful in regard to any other question of the day, but no Congressman can be elected who declares his open hostility to the saloon. The liquor interest dictates the main part of the editorial utterances on matters relating to temperance, and its influence is not absent from the assembly and the pulpit.

No other social institution is so arrogant in its selfassertion as that which represents the saloon. If the social spirit were Christian, would it find such dominant expression through the saloon and its accompaniments? 
More than this, would the saloon be able to exert such a controlling influence over other institutions?

It is an open fact that the Government in this country is dominated by saloon interests. The liquor power met with some reverse in the abolition by law of the beer canteen in the army, but it is being strengthened at other points. Never in the history of the country was this institution more influential in high places than now. Few are the newspapers which refuse to carry liquor advertisements, and fewer still the politicians who would venture to offend this oligarchy by turning down their glasses at a public banquet. Could such an institution dominate social action in a Christian State in this present time? Law as the Expression of the Social Spirit.

The history of certain periods is mainly constructed on the belief that the laws belonging to any era express the ideas of the time. When one takes up the Roman code, and finds what actions were forbidden, he concludes that these actions were so far prevalent as to call for social control, and also that they were considered harm$\mathrm{ful}$ to the State. When we find in certain periods of the Middle Ages that laws were passed against the excesses of the clergy we make the inference that reformation was needed in the Church. In some cases these scraps of legislation are about all the records that are obtainable, and from these the historian constructs his society as the scientist builds an animal from the bone which he discovers. In our age, when the records are so complete, it is not so necessary to get our ideas of the character of society from the laws upon the statute books, 
but it is true now, as long ago, that the laws of any age are a fair expression of its life. They reflect with a fair degree of exactness the morality of the people. In our political system the fundamental law, upon which all legislation rests, is found in certain documents known as Constitutions. For this reason it will not be necessary to examine the secondary laws, since they are but the applications of the principles of the fundamental law. The Constitutions are made by the people, and from their character we may with a good degree of certainty fix upon the character of the life which forms them, thus aiding in the determination of the question whether this is a Christian State. These fundamental laws may be treated in the order of their enactment and also of their importance. They may be classed under the heads of Charters and Colonial Constitutions, Commonwealth Constitutions, and Federal Constitution.

\section{Colonial Charters and Constitutions.}

For two reasons the charters are not of the first importance in determining the present character of the American State; first, they were issued nearly three hundred years ago, and, second, they were neither framed nor adopted by the colonists themselves. In all cases they were esteemed a grant of privileges from the king, which might be revoked at his sovereign pleasure. They can not, therefore, stand on a par with the Constitutions as expressions of the social life. Some of the Charters, notably that of Rhode Island, expressed the ideas of the dominant spirit in the Colony, but not every settle- 
ment had Roger Williams to plead its case. For the most part, the men who had to do with framing the Charter were not residents of the settlement to which the document related.

Whatever may be thought of the expressions, religious or otherwise, which are found in the Charters, it may be said in the words of Lord Beaconsfield, when someone accused him of being inconsistent with a former utterance: "A great many things have happened since then." The intervening centuries, especially the one which has just closed, have been marked by an imimense influx of settlers with diverse beliefs and practices. For better or for worse, these have exerted no little infiuence upon the social character. Scarcely may it be said that one-half our present population is made up from the descendants of those who came to this country before I820. In I775 Bancroft thought that there was about one-fifth of the population which was not English; in I890 one-third of the population was either of foreign birth, or had one or both parents born abroad. For these and other reasons, the statements of the Charters can furnish no more than an inference as to the present social character.

The point in the Charters with which this chapter is specially concerned is the matter of religious features. In this respect one does not expect very much from the Stuarts of England, therefore is in less danger of being disappointed at the meagreness of what he finds. One expression in common use in these royal documents is, that the king held his position "by the Grace of God," 
which referred much less to his dependence on God than to his independence of the English people.

Another religious feature which received more attention in the Charters than in colonial practice, was the reference to the conversion of the Indians. Judging by the wording of the Charters, this purpose was a leading motive in organizing the colonial trading companies. In the Virginia Charter, given by the gracious will of Jar.es Stuart, in 1606, article third reads: "We greatly ccmmending, and graciously accepting of, their Desires to the Furtherance of so noble a Work, which may, by the Providence of God, hereafter tend to the Glory of his Divine Majestie, in propagating of the Christian Religion to such People, as yet live in Darkness and miserable Ignorance of the true Knowledge and Worship of God, and may in time bring the Infidels and Savages, living in these parts, to human Civility, and to a settled and quiet Government."

In the Second Virginia Charter, given by the same gracious hand in 1609 , we find a declaration of the intention, "by the assistance of Almighty God to prosecute the same (enterprise) to a happy End." The Patent for the Council of New England differs only in details from the expressions already cited. In this document the king refers to the fact that " within these last Yeares there hath raged a wonderfull Plague together with many Slaughters and Murders, committed among the Savages," inhabiting the district of Massachusetts. He accordingly thanks God that this fact of the decimation of the Indian tribes had been hid from other kings so 
that the English might get the land.. "We in our Judgment are persuaded and satisfied that the appointed Time is come in which Almighty God in his great Goodness and Bountie toward Us and our People, hath thought fit and determined that those large and goodly Territoryes" should be taken by such of the subjects of King James as should be conducted thither. This opening for a trading company leads him to say further: "In Contemplacion and serious Consideracion whereof, We have thought it fitt according to our Kingly Duty, soe much as in Us lyeth, to second and follow God's sacred Will""which tendeth to the reducing and Conversion of such Savages as remain wandering in Desolacion and Distress, to Civil Society and Christian Religion, to the Inlargement of our own Dominions." This faculty of combining the conversion of the heathen with the interests of trade has such a smack of modern ethics that one feels that history is repeating itself.

It was not the thought of either king or Parliament that they were laying the legal foundations of a future State. It was the thought of the time that they were commissioning a trading organization, such as the Hudson's Bay Company, which monopolized the fur trade of the Northwest, or the East India Company, which looted the treasures of the native princes of India. With this fact in mind, it may seem strange to us that religious features appear at all.

It is to be noticed, however, that none of these religious acknowledgments make the authority of Christ and His law paramount in the conduct of the enterprise. 
This idea may have been in the mind of some of the promoters of the colonies; it may have been in the mind of the settlers, but it was not written in the Charters. They confess the being, the goodness, and the general control of God in providence, but no single Charter professes to take the law of Jesus Christ as the rule of life. The conclusion follows, therefore, that the Charters, even when we pass over the fact that they were given two hundred and fifty years ago by a foreigner, do not give evidence that the State is Christian. To have Christian features and to be Christian are not identical propositions.

\section{The Fundamental Orders of Connecticut.}

It is not in the Charters, given by an English king, but in the Colonial Constitutions, framed before the middle of the seventeenth century, that we find the clearest acknowledgment, that American history furnishes, of the supremacy of God in civil affairs. The Fundamental Orders of Connecticut, framed for the government of the neighboring towns of Hartford, Windsor, and Weathersfield, was the first written Constitution which any community in America made for itself. In this respect it was unlike the royal Charters, since it was an expression of the life of the community. "Well knowing," reads this Constitution, "where a people are gathered together, the Word of God requires that to mayntayn the peace and union of such a people, there should be an orderly and decent Government established according to God, to order and dispose of the affayres at all seasons as occasion shall require." For the instruction of the 
governor and his assistants it was ordered that, "being chosen and sworne according to an oath recorded for that purpose they shall have power to administer justice according to the Lawes here established, and for want thereof according to the rule of the Word of God." Thus did these early settlers accept the law of God as the rule of conduct in political affairs.

The Fundamental Articles of New Haven.

This Constitution was written, in the same year as that framed for the Hartford people, by the burgesses of New Haven. Like the men in the Connecticut Valley, these settlers on the shore of the Sound were refugees not only from political and ecclesiastical oppression in England, but from unsatisfactory conditions in the older Colonies about Massachusetts Bay. It was to set up a Scriptural form of Government that they had pushed so far into the wilderness, and they do thorough work. In June of 1639 they come together "to consult about settling civill affairs according to God." This New Haven document had its principles stated in the form of queries to which the people assembled gave assent or expressed disapproval after discussion. One of the queries reads: "Whether these Scriptures doe hold forth a perfect rule for the direction and government of all men in all duties which they are to perform to God and men, as well in the government of famylyes and commonwealths as in matters of the church." This was twice read and assented to by all present.

These popular Constitutions were set aside by the 
Charter of Connecticut which was granted by Charles Second in I662 to certain "of our loveing Subjects," and the acknowledgment made by these little companies of earnest men, of the divine authority in political affairs, has found no parallel in the official papers which have been issued in the centuries since.

One other document of this period deserves notice, less because of the matter in it than because of the circumstances connected with its issue. This was the Mayflower Compact, drawn up and signed in the cabin of that vessel, previous to the landing in 1620 . It was intended less as a basis for any general frame of Government than to hold in check certain disorderly members of the party, who had declared that on landing "they would use their own liberty," since the settlement was north of the territory over which the Virginia Company, from which they held their patent, had jurisdiction. Within the lands of that Company they admitted the force of its rules, but outside its boundaries they wished to be independent of control. The Compact reads: "In the name of God, Amen," and further states that "for the glorie of God, and advancement of the Christian faith, and honour of our king and countrie," they had undertaken to plant a colony in Northern Virginia.

The Puritan Not the Typical American.

These are the expressions in law of the ideas of the Pilgrims and the Puritans of New England in an age when persecution had heated their lives above the moral temperature of the materialistic formulas of later date. 
But it is sometimes necessary to call to mind that these expressions are not typical of what might be expected from the Kennebec to the Savannah. South of the Hudson they read their Bibles quite differently, if they read them at all. The moral atmosphere suffered a marked change when one left the Connecticut River behind him on his way through the Middle Colonies. The Puritan population was of that from which Cromwell constructed his famous "Ironsides," with a larger number of University men than could be gotten in the same population in an English county.

The Southern Colonies, on the other hand, were flooded with indentured servants and ruffians pressed from the London streets, and this motley crowd submerged the scattered communities of Scotch-Irish and Huguenots. While the Puritan was careful beyond comparison in the observance of the Sabbath, the bulk of the population in the South made it a day for amusements and broils.

The Puritans did not equal one-fourth of the total population in the eighteenth century, and perhaps onehalf in the seventeenth, so that the colonies, as a whole, were not of the Puritan type. Outside of New England, it may be questioned whether the laws of God were reverenced in the early days more than at the present time. The writer who maintained that the Carolina settlers reverenced "neither God nor man" may have exaggerated the irreligious character of the people, but in any case this community had very little of the Puritan flavor. There is considerable trouble experienced by the modern who attempts to characterize the typical Amer- 
ican, and there would not have been less two hundred years ago. One runs no risk in making the statement that while the Puritan contributed much of the iron in the blood of the coming race, he did not furnish the typical American of the seventeenth century. We may not therefore take his religious beliefs, as is often done, as typical of the convictions of the colonists as a whole. One who studies the records of the contemporary historians previous to the American Revolution will scarcely conclude that the typical citizen of those days was a Christian, nor that the country as a whole was dominantly Christian.

\section{Commonwealth Constitutions.}

Throughout these chapters the term Commonwealth is used instead of the term State, when designating a portion of the country, to prevent confusion with State, the social spirit, or nation. The word Commonwealth is in common use, so that it will require no explanation further than this statement.

When the Continental Congress in 1776 declared the people independent of English jurisdiction, the individual Colonies were left, with few exceptions, without a frame of Government. The Charters under which they had enjoyed a good measure of self-control had been revoked by the king, and their assemblies outlawed. Massachusetts had supplied the place, by Committees of Correspondence, but this could serve only a temporary purpose. It was evident that some new method must be inaugurated to meet the exigencies of the situation. In 
this crisis the Colonies applied to Congress for advice as to what they ought to do. Congress replied that each Colony should frame a Constitution for itself, a recommendation which met the wishes of the people so entirely that they at once proceeded to put it into practice. It does not appear that any one of the Colonies acted without the Congressional advice and oversight, so that the unity of the people under a central Government was recognized from the beginning of Commonwealth existence. The facts of this period do not give aid or comfort to the exponent of "State Rights," however the wording of the public documents may sanction his views.

In the years from 1776 to 1780 nearly all of the Commonwealths framed Constitutions and became self-governing communities.

In comparing the religious features of these instruments with those of the Charters of earlier date, no radical change is to be noted. The name of God occurs with less frequency, but as neither Charters nor Commonwealth Constitutions acknowledged the authority of God in political affairs, there was no special departure from the precedent set by the Charters. There is nothing in the Constitutions of the Commonwealths to recall the acknowledgments made by the settlers at New Haven and Hartford. These examples from Connecticut stand alone in American history.

Under the Charters an oath had been required of public officials, and the same was the rule under the Commonwealth Constitutions. Pennsylvania and Delaware framed Constitutions in 1776 , which allowed for an affirmation 
instead of the official oath, but both required of the candidate for political positions a declaration of a belief in God and in the inspiration of the Scriptures.

This clause in the Constitution of Delaware reads: "I do profess faith in God the Father and in Jesus Christ His only Son, and in the Holy Ghost, one God blessed forevermore; and I do acknowledge the Holy Scriptures of the Old and New Testaments to be given by divine inspiration." While this is an explicit requirement that the candidate shall be a Christian, it does not confess the authority of God in civil affairs. In other words, it is a personal, not a social, confession of faith.

It is worth noting as an evidence of the influence of the irreligious character of the Federal Constitution, and the decadence of the times, that Delaware revised this clause from its Constitution in I792, substituting the test clause from the Federal Constitution: "No religious test shall ever be required as a qualification," for holding office.

In I780, Massachusetts required a belief in the Christian religion as a condition of holding office, and in the same year the Constitution of North Carolina required the acceptance of the Protestant religion by its officials. These requirements indicate that while the law of Jesus Christ had not been accepted as the rule which should be supreme in civil affairs, the people judged it necessary to insist on Christian qualifications in the man whom they would entrust with political power. This is not an unusual sircumstance. The merchant who sands his sugar, puts talc in his flour and chicory in the coffee, may yet insist 
upon Christian qualifications in the men whom he employs to sell the goods. They must be Christians, but not to that extent that they refuse to handle adulterated goods. The clerk may be expected to give short measure, but must not falsify the books. Men frequently want a Christion official to administer unchristian law.

This may serve to explain, in part, why the test of Christianity was applied to the official, and not to the law which he had to administer; it guarded personal responsibility of the official to the people, and ignored the social responsibility of the society to God. The Constitutions of the different Commonwealths, based the authority for the execution of the functions of Government solely upon the sovereignty of the people. The initial phrase of the Federal Constitution - "We the people — do ordain and establish this Constitution "was not original with the members of the Constitutional Convention at Philadelphia in I787. It was copied from the Constitutions of the Commonwealths..

None of the Commonwealths made any confession, in their Constitutions, of the authority of Jesus Christ in political affairs, nor of the supremacy of His law in moral questions. Some made mention of the existence of God, some of His goodness, but none of His authority. Massachusetts, in the Constitution adopted in 1780 , makes the following declaration: "We, therefore, the people of Massachusetts, acknowledging with grateful heart the goodness of the Great Legislator of the universe - do agree upon, ordain, and establish, the following declaration of rights and frame of government, as the Constitu- 
tion of the Commonwealth of Massachusetts." This declaration, which finds substantial parallels in other public documents of the same date, confesses the goodness of God, but it lays no obligation upon the official acting under it to enact, or to interpret, laws in harmony with the law of God. Such forms of expression have, therefore, no legal value whatever. They are only expressions of sentiment, which need have no influence on the conduct of the Government.

This is the particular fact to which attention is called. The acceptance of the law of Jesus Christ as the rule of life is what constitutes a Christian. The lack of this acceptance disallows of either individual, or institution, claiming the name of Christian. Therefore, the conclusion seems necessary that the expression of the social life through the Commonwealth Constitutions, does not indicate that the State was Christian previous to 1787 .

The fundamental civil law of the land is the Federal Constitution, and therefore it is the chief subject of study when one wishes to determine the character of American law. During a century it has expressed the life and moulded the law and the ideas of the people. Once it had a radical change, as the result of a revolution in sentiment brought on by the Civil War; hundreds of amendments have been proposed, fifty being offered during the recent session of Congress, yet it would scarcely be disputed that the Constitution, so far as its moral character is concerned, satisfies the people as well today as in its earlier years. For this reason the Federal Constitution may be taken as furnishing the moral standard 
which the American people would have in law. By studying what the people like, we can learn what the people are. So long as the social spirit does not demand changes in the law, it is fair to conclude that the law gives satisfactory expression to the social life.

\section{The Federal Constitution.}

The forms of law which have been cited belong to the past, and are expressions of past life. The Federal Constitution is the accepted expression of the social life of the present. It is, therefore, to its features, rather than to preceding forms of law, that we turn for evidence as to the present character of the State. If the Federal Constitution is Christian, it would be a fair inference that the State, of which it is the expression, is Christian; if the Constitution is not Christian, it will be equally strong evidence on the other side.

The Decline in Religions Expression.

We have already noticed that the clearest, in fact the only, acknowledgment of the supremacy of God in civil affairs found in any American Constitution of Government was that made by the Cc:anecticut settlers in 1639 . Religious expressions are frequent in the Commonwealth Constitutions of 1776 and succeeding years, though they diminish witis each revisican of these instruments of Government. In the Federal Constitution they do not appear. The reason for this decline in religious expression in the Constitutions is apparent. The adequate expressions of the authority of the law of God were made by small and 
select communities, where there was little divergence in interests, or belief. As the population increased in these centers it was drawn from various sources, it included elements of entirely different character. Something else than religion became the dominant interest in the neighborhood. The same people, or their descendants, are still there and still have an influence on the neighborhood life. But they have changed in character, or have ceased to exercise so much influence.

This change is emphasized when these communities are drawn together in the larger unity of the Commonwealth. In this union a larger variety of belief, or unbelief, was included, which demanded the modifying, or even the exclusion, of the religious features in the law. The Constitution of the Commonwealth had its character modified to suit the spirit which it expressed.

The Constitution of the United States makes a still greater departure from the Connecticut model of 1639 . When the heterogeneous population reaching along the whole Atlantic seaboard, a population including a large body of uni ent, sought to find expression for their political beliefs through a single document, that document contained no religious features. Not only are religious expressions absent from the Federal Constitution, but they are debarred by its own explicit provision. It is avowedly agnostic.

One fact deserves notice before leaving this phase of the subject. The Federal Constitution, while it did not follow the precedent, set by the Commonwealth Constitu- 
tions, of demanding an oath from the candidates for official position, or requiring a profession of their belief in Christ, agrees with them in not taking the law of Christ as the standard of official conduct. None of the Commonwealth Constitutions had such requirement, nor was such made, subsequent to the New Haven act of 1639. This act required conformity to the divine standard of legislation; the Commonwealth Constitutions made the demand that the official should be a Christian; the Federal Constitution prohibited any requirement of personal or social religion. Such was the progress of the years, toward the total ignoring of God in the fundamental law of the land. Before turning to the internal evidence of the Constitution itself on this point it may be well to consider some counter-claims in regard to the character of this Constitution.

Gladstone declared the Constitution of the United States the greatest production struck off by the mind of man at a single sitting. While there was but a single feature in this frame of Government, the provision for the election of the President, that was not taken from Colonial precedent, one is inclined to agree with the English eulogist, that no other country can boast its equal.

Carefully did it guard the rights of man, except where it riveted the fetters of the slave; but in this did only what was done at that time by the laws of every country to which the black man had been carried. Wisely were the powers of Government divided between the departments. With patience were its measures fused over the fires of prolonged debate. The greatest minds which this 
country could furnish shared in the deliberations. It was a magnificent piece of work; but it was not Christian. It Was Made by Christian Men.

It is sometimes said that it was made by Christians, and that therefore it is Christian. As to the religious convictions of the men who met in Philadelphia during the Summer days of 1787 , to propose a frame of Government which would " meet the exigencies of the Union," it would not be possible to draw final conclusions. Some of them were avowed Christians; some were avowed unbelievers. 'Which factor had the majority in the Convention can not be determined after this lapse of time.

It may throw some light on the dominant influence in the Convention to recall that none of is sessions were opened, or closed, with prayer. No reason is at hand to account for this departure from the prevailing custom. On the 28th of May, when the differences between the large and the small Commonwealths over the question of representation seemed on the point of disrupting the Convention, Franklin proposed that prayer should be offered daily. "In this situation of the Assembly, groping as it were in the dark to find political truth, and scarce able to distinguish it when presented to us, how has it happened, Sir, that we have not hitherto once thought of humbly applying to the Father of lights, to illuminate our understandings? In the beginnings of the contest with Great Britain, when we were sensible of danger, we had daily prayer in this room for the divine protection. Our prayers, Sir, were heard, and they were graciously an- 
swered. All of us who were engaged in the struggle must have observed frequent instances of a superintending Providence in our favor. To that kind Providence we owe this happy opportunity of consulting in peace on the means of establishing our future national felicity. And have we now forgotten that powèrful friend? Or do we imagine that we no longer need His assistance? I have lived, Sir, a long time, and the longer I live, the more convincing proofs I see of this truth - that God governs in the affairs of men. And if a sparrow can not fall to the ground without His notice, is it probable that an empire can rise without His aid? We have been assured, Sir, in the sacred writings that 'except the Lord build the house, they labor in vain that build it.' I firmly believe this; and I also believe that without $\mathrm{His}$ concurring aid we shall succeed in this political building no better than the builders of Babel."

Hamilton and others expressed the fear that having recourse to prayer at that time might lead the public to conclude that they were seriously embarrassed; Franklin rejoined that the omission of a duty could not justify a further omission, and that the rejection of the proposition would subject the Convention to adverse criticism. Mr. Randolph proposed, in order to give color to the proposed change, that a sermon be preached on July

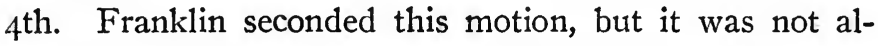
lowed to come to a vote, that act being prevented by adjournment. There is no record of the proposal being renewed at later sessions. Whatever may be said as to the character of the members of the Convention, it seems 
a fair inference that the religious idea was not a controlling factor in the proceedings.

\section{The Constitution a Product of Christianity.}

It is sometimes claimed that the Constitution is Christian because its provisions are an outcome of Christianity. Undoubtedly the Constitution would not have been without the influences that flowed from the life and death of Jesus Christ, but would that make it Christian? The freedom of thought and action which it proposes did not exist until Christianity gave it birth. It does not yet exist where the influence of Christianity is not felt. But while modern civilization would not have been what it is without Christianity, it is a large assumption which calls all its elements Christian on that account.

The infidel is allowed to declaim or publish his blasphemies today practically without hindrance; before the work of Jesus was done he would have suffered the death penalty for such an offense. Because Socrates spoke against the gods he was compelled to drink the hemlock. Such was the fate of the infidel before Jesus won toleration for friend and foe alike. Though the modern infidel is a by-product of Christianity, it does not follow that he is a Christian. The individual, or the institution, may reap the temporal benefits of the work of Jesus Christ, while refusing to confess the name of the benefactor. This the American State has done. It appropriates the gift and in its fundamental law denies the giver. "Ingratitude, more strong than traitors' arms," has ruled in the counsels of the nations. 
The Date of the Constitution.

Some have seen in the dating of the Constitution, " in the year of our Lord," an acknowledgment of Christ. But if that constitutes it a Christian instrument, then every letter which is written with a date upon it, deserves the name. This would assert that the letters of Voltaire and Thomas Paine were Christian documents, as well as those written by Calvin, or Luther. Everyone who writes $\mathrm{A}$. D. on his production does not by that act prove its Christian character.

But there is another line of objection to this sweeping claim. All treaties made under the Constitution become a part of the supreme law of the land. Now the treaty with Tripoli, ratified in 1798 , bears also the Mohammedan dating, "in the year of the Hejira I2I I," so that if one date recognizes Christ the other must acknowledge Mohammed. As a matter of fact, neither dates have any religious significance in the connection in which they are found.

The character of the Constitution must be settled by a study of its provisions. It has been already claimed that it is a product, one of the finest products, of civilization. By this Constitution, then, may the character of the civilization be known. The purpose of this chapter is to determine whether or not the American State is Christian. Taking the Federal Constitution as one of the ripest products of the age, it becomes a fitting subject of investigation in determining the character of the age, and of the American State. It is with this idea that we turn 
to the study of the religious character of the law of the land.

\section{The Preamble of the Constitution.}

This is the section of the Constitution on which each succeeding item depends for its sanction. All the provisions of the instrument rest on the authority of the people. The preamble reads: "We the people - do ordain and establish this Constitution for the United States of America." The Constitution, therefore, rests on the will of the people and acknowledges no higher authority. It is by profession a supreme law made by $\mathrm{a}^{-}$ supreme people. As has been stated in a previous chapter, it is thoroughly in agreement with the principles governing the delegation of authority in political and industrial affairs, that the Government should be made thus to acknowledge the authority of the State which called it into being.

In another respect, however, the Constitution fails to conform to the general principles governing such delegation, since it does not recognize the authority of Jesus Christ over the State. The people is the immediate source of authority in Government. That much is true. But the people is not the ultimate source of authority. The State is superior to the Government, but the State, in its turn, is inferior to the higher power. This fact should be stated in the preamble which assumes to lay the foundation for political action. As the preamble stands, it gives the State the supreme place, thus putting the people in the place of God. This was practically the 
view of Comte, who held that humanity was God, to whom the worship of the citizen was due; and while this idea was doubtless not in the mind of the designers of this preamble, their denial of the supremacy of the Lord, leaves no other alternative.

It is said that this acknowledgment of the authority of the people implies, while it does not state, the supremacy of a higher authority. But the necessary interpretation of other parts of the Constitution makes this position untenable. The Convention which declined to appeal to Jesus Christ in prayer also refused to accept Him as the ruler of the State. Since we have defined the Christian as one who accepts the law of Christ as the rule of life, it is quite evident that the Constitution, which puts the will of the State in place of the will of Christ, does not deserve the name.

\section{The Official Oath.}

Previous to 1789 it had been the uniform rule to require that Government officials should be inducted into office by the use of the oath. This, in the nature of the case, was an appeal to God, and therefore served as a religious test. It is quite another thing from taking the Word of God as the rule by which the moral questions arising in the performance of his official duties should be judged. Yet this requirement discriminated against the unbeliever in favor of the Christian, and was a religious feature common to all the Constitutions of earlier date. The Constitution of New Jersey, made in 1776 , is one of the few cases, if not the only one, where the Com- 
monwealth did not require an oath of the candidate for office. The twenty-third item in the New Jersey frame of Government reads, in part: "I, A. B., do solemnly declare, eic." In many of the Commonwealths exception was made in favor of the Quakers who had conscientious objections to the use of the oath. The Constitution of the Commonwealth of New York furnishes one instance of this exception in favor of the Quakers. The clause relating to the oath reads: "That every elector, before he is admitted to vote, shall, if required by the returning officer or either of the inspectors, take an oath, or, if of the people called Quakers, an affirmation of allegiance to the State." It had been customary, in many instances, to use the words "swear, or affirm," but the appeal to God at the end of the formula was retained.

It is because the oath had been uniformly required of the elector and the official previous to the formation of the Federal Constitution, that the omission of the oath from the Constitution makes a departure from precedent. In the second article of the Constitution, the formula is given which the President of the United States is required to take at his inauguration: "I do solemnly swear (or affirm) that I will faithfully execute the office of President of the United States, and will to the best of my ability, preserve, protect and defend the Constitution of the United States." It has been the custom of the Presidents to add an appeal to God in their use of this formula, but it is not in the bond. The Constitution does not require that Government officials shall believe in God, and the citizen who makes such a demand of a candidate 
as a condition to giving him support, is laying down an unconstitutional requirement. To ask that a candidate shall be a Christian is to ask that he shall be better than the law which is to guide him.

For conclusive evidence that the substitution of an affirmation for an official oath was not through any oversight, but of deliberate purpose, we have only to turn to the records of the different drafts of the Constitution submitted to the Convention. The original draft proposed by Randolph on May 29th contained this clause: "Resolved, That the legislative, executive, and judiciary powers, within the several States, ought to be bound, by oath, to support the articles of union." The Pinckney plan provided that the President "At entering on the duties of his office shall take an oath faithfully to execute the duties of the President of the United States." It is thus made clear that the first drafts before the Convention followed the former custom of requiring an oath from the President of the United States and other Government officials, and that the change, to mere affirmation instead, was made with the question before the mombers.

Some days later, on August 6th, the committee to which the various proposals had been submitted, rcported the form of oath, or affirmation, provide $d$ for the President, as it is found in the Constitution. At the same time the committee reported the followin $\mathbb{G}$ I rovision for other officials : "The members of the legislatures, and the executive and judicial officers of the United States and of the several States, shall be bound by oath to support the Constitution." On August 3oth the words "or affirmation" 
were inserted after the word "oath." This provision of the Constitution, which appears as the last paragraph of Article 6, had its phraseology changed somewhat in later revisions, but the wording concerning the oath remained as stated here. It was in connection with this section that the religious test clause was moved by Pinckney, and was unanimously adopted by the Convention. While the records of the Convention do not witness to any debate upon the emasculation of the oath, it is evident to anyone who follows the testimony at hand, that the matter had due consideration. 'The first drafts rea quired an oath; the later revisions omitted it. There is a consistency in the whole proceeding which forbids any thought of negligence. The result of dropping the requirement of the oath for officials was seen soon after in the action of Congress. The House of Representatives, in session May 6th, I789, adopted the following oath for use by its members: "I, A. B., do solemnly swear (or affirm, as the case may be) in the presence of Almighty God, that I will support the Constitution of the United States, so help me God."

The first statute which appears upon the record of the acts of Congress, bears the date of June Ist, I789, and reads in part as follows: "I do solemnly swear (or affirm, as the case may be) that I will support the Constitution of the United States." This remains as a law of Congress, and conforms to the requirements in the Constitution. When the name of God was excluded from the supreme law, inferior law hastened to fall into harmony with it. By these easy stages did the name of God 
cease to have any legal place in the official language of the Republic. It is frankly admitted that the name of God, unless taken reverently, has but little meaning; yet the patriot must look with some anxiety on those proceedings in the Constitutional Convention, and the Congress meeting under the Constitution, which deliberately excluded that name "which is above every name" from the supreme law of the land.

In the scanty records which remain of the proceedings of the ratifying Conventions there is but slight reference in the debates to the substitution of affirmation for an appeal to God. The objections raised to the Constitution on that point must have been few. Evidently the delegates were not greatly shocked by the omission. One reference to the matter is credited to Henry Abbott of North Carolina. "Some," he said, " are desirous to know how and by whom we are to swear, since no religious test is required - whether they are to swear by Jupiter, Juno, Minerva, Prosperpina, or Pluto." The recurd does not show that he received any information on the matter.

\section{The Test Clause.}

The third paragraph of Article 6 of the Constitution reads: "No religious test shall ever be required as a qualification to any office or public trust under the United States." Under the previous citations it might be possible to advance the claim that the Constitution had failed, if at all, through omissions, rather than by any positive provision. But in the test clause quoted there is an explicit prohibition of any religious feature in the Con- 
stitution.

What is a religious test? Perhaps a more definite knowledge of its meaning may be gained by a reference to a political test, with the working of which all are familiar. When a foreigner wishes to become a citizen of the United States, there are certain conditions which he must satisfy. If he is an Englishman, he must give up his allegiance to the king and exchange the monarchy for the Republic; he must abjure any allegiance to a foreign State. This is a political test, and unless the embryo citizen is willing to take this test the court must refuse naturalization.

Now the meaning of a religious test is equally clear. If a Mohammedan were ordered to give up the Koran, or the Hindoo to abjure the Vedas, it would constitute a religious test. If these parties were asked to accept any institution, or teaching, which was distinctively Christian, it would be a religious test. Now to apply these illustrations to the matter in hand, if the Federal Constitution required of those who owned allegiance to it, a belief in God, or in the supremacy of His law, it would be a religious test to the citizen who did not believe in God, or in the supremacy of His law. It is, therefore, expressly forbidden by this clause, that any religious expression, Christian or otherwise, should appear in the Constitution. Any other conclusion would allow one part of the Constitution to contradict another.

It has been suggested that the prohibition was aimed at sectarian rather than religious features. But if this had been the case it would seem strange that the right word 
had not been used by the scholarly men who composed the membership of the Convention, or by Gouverneur Morris, who is said to have chiefly influenced its diction. Had the intent been to prevent discrimination between Christian denominations in political action, it would have our approval, though the danger of such discrimination would have been imaginary.

But the circumstantial evidence does not admit of such an interpretation of the test clause. It was clearly the intention of the Convention that all religious features should be excluded. The reference to the name of God had already been expunged from the official declaration. The first Congress embodied this idea in a statute. In the Fifth Congress, where many of the same men, or their influence, remained, a treaty was ratified with Tripoli. As the Mohammedans have always stoutly insisted that the earth of right belongs to Islam, and that no other power is on an equality with the Mohammedan States, it was thought necessary to conciliate them in this treaty. To this end a clause was inserted in the treaty which declares: "As the Government of the United States of America is not in any sense founded on the Christian religion, it has in itself no character against the laws, religion and tranquillity of Musselmen." This was signed by the President, John Adams, and endorsed by the Senate of the United States, the members of which, we may suppose, understood the nature of the Constitution under which they acted. It does not seem that the evidence of the unchristian character of the Constitution admits any possibility of rebuttal. Would that it did! 
One more citation as to the intention of the framers will suffice. To the Presbyterians of New Hampshire and Massachusetts who complained of the "omission of God" from the Constitution, Washington replied in the Massachusetts Sentinel of December 5th, I789. In this open letter he said that religion had been left out of the Constitution "because it belonged to the churches, and not to the State." This gives us the statement of the President of the Philadelphia Convention that the Constitution has no place for the Christ, or His law, and states the reason for ignoring them. It is not atheistic, since it does not deny the existence of God; it is agnostic, since it does not know Him.

\section{Supreme Court Decisions.}

The Courts have sustained this view of the Constitution at different times, but there is a more simple test of judicial action which anyone, without having recourse to the Court records, may apply. The Courts are ruled by the Constitution, and the principles contained in that instrument outline their official code of conduct. Now the Bible is the text of Christianity, and if Christian principles are in the Constitution, the Courts would have to be guided by the Bible in their decisions on moral questions. If it is not in the Constitution as a ruling principle, it would be mere sentiment at the best, without any legal value. Has anyone known of the Courts basing their decision for, or against any party, on Bible teaching? They have never done so, and it would be in direct contravention of the Constitution, the official guide of the Courts, that such action would be taken. 
The theory of the Convention at Philadelphia in 1787. that the Government can be neutral in the matter of religion, is impossible in practice. Every people has its theology; every institution has its code of morals. In practice some standard is taken, and all others rejected. It is not at all a question of whether a moral standard shall be chosen, but which one shall be chosen. When the Constitution, and the Government acting under it, as well as the State acting through it, barred Christianity as a ruling principle from the fundamental law, they by that act accepted some other standard. What that principle was, or what it is, may be a question difficult to answer satisfactorily, but that is the only question.

It has been suggested in a former chapter that in practice the ethical theory of Weismannism, of natural selection, is the one in general use. At least the people, ucting through their representatives, rejected Christianity as the governing principle in political morals. What the Jew emphatically declared, has the American implied, we will not have this man to rule over us.

This closes the argument in regard to the character of the American State. A few of the leading social institutions have been studied; a few points noted in regard to each. The reader will decide from the social facts considered, or from others that seem to him more important, on the proper answer to the question. To the writer it does not appear that the candid student can be long in doubt as to what the answer must be. Scarcely will anyone claim that our political and industrial methods conform, even by profession, to the teachings of Jesus. 
These comprise the larger part of the social practice, and our conclusions might rest upon this basis alone.

The saloon, which is sanctioned by law, and which is such an important factor in political control, is notoriously unchristian.

The school gives only a partial education, since it excludes, as a text, frequently even from reference, the Bible, which is the chief text-book of the led-out life.

The fundamental law excludes the Christ. Is the State which expresses itself through these institutions a Christian State? Only an exceedingly narrow definition of the word Christian would make an affirmative answer possible.

The Regeneration of the State.

In this lies the nation's hope. That the Spirit of the Kingdom may permeate the social spirit is the patriot's prayer; the supreme end of his labors. Some may disagree with the conclusions drawn above in regard to the character of the State, but surely there is not a Christian who will raise a question as to the social end to be gained. The social spirit must be born into the higher life. The Word of God should be the text-book of the present pupil, the future citizen, in the common schools. Only thus can a citizenship be trained which will ensure the permanence of republican institutions. All institutions should be transformed by the Spirit of Jesus, and those which are alien to the Kingdom must be banished from the social life.

There is need of such change in law as shall acknowledge Jesus Christ as the King of the State, and His law as 
the legal standard of morals to which officials, high and low, shall look as the measure of official duty. This demands not simply a formal but a spiritual change. There is not any popular demand for a change in the Constitution toward the expression of a larger Christianity. This demand must be created before such change can be had. Such fundamental change in law requires an antecedent change in the social life which expresses itself through that law. This may place Constitutional change, that shall make the Government Christian, far in the future, but not farther than the facts warrant. The Spirit cometh "not with observation," so that the glorifying of the Christ by the American State may not be so far future after all. There must come to the social mind a new conviction of the rights of Jesus Christ, to call out a social profession of faith in Him. To secure this end is the Christian's duty and in its fruition the patriot's reward. Jesus prayed and died for that end, and not in vain. It is in the firm belief that the Holy Spirit will inspire earnest men with the stern resolution to win America, and the world, for the Christ, the King, that this book has been written and sent on its errand.

Journal of the Constitutional Convention, Madison; Elliott's Debates; Selected Documents from 1606-1775, Macdonald; Origin of Republican Form of Government, Straus; Critical History of Sunday Legislation, Lewis; Our National EducationIs It Christian or Secular? Wylie; Dying at the Top, a Statement of Religious Conditions, Clokey; The Christian Society, Herron. 
a 


\section{INDEX.}

Aristocracy, 1.58.

Aristotle, social theories of, 73 . Authority-

-delegated to Jesus Christ, 250.

-delegated to the State, 257.

-delegated to the Government, $26 \mathrm{I}$.

-delegated to officials, municipalities and corporations, 268.

- general principles governing delegation, $27 \mathrm{I}, \mathrm{ff}$.

-its source, 247.

-its delegation, 249.

Bagehot, referred to, $12 \mathrm{I}$.

Bluntschli, quoted, 202.

Burgess, referred to, 219, 295.

Christian, defined, 305.

Christian State, defined, 308.

Christianity and the social conscience, 153.

Church, as a social institution,

-and State, 56.

49.

-and State, reason for uniting, 60 .

-and Government, 58, ff, 65 , I57.

-as related to other institutions, 5I, 57 .

-defined, 65 .

-the character of, 3 II.

Comte, referred to, 97,343 .
Conscience and habit, 142.

-generalizes, 143.

-social, defined, I4I, I45.

Constitution and colonial charters, 322.

Constitutions, commonwealth,

Constitution, federal, 335 .

- character of, 335.

- product of Christianity,

340.

Coulange, De, quoted, 102, 193.

Darwin, referred to, 177.

Democracy and the social conscience, 155 .

Dunning, referred to, 306 .

Education, its meaning, 315. ff. Ethics, dualism in, 196.

Ethics of natural selection, 186 .

-illustrated, I90, ff.

Family, patriarchal, 45.

-its varied functions, 45 , ff.

Feeling, social, I3I, ff.

Franklin, quoted, 338 .

Freedom, its development,

-its conditions, 22I: $2 \mathrm{I} 4$, ff.

Government-

-identified with State, 17.

-without justification, 22, 25.

-effect of revolution on, 32.

-suggested in family, 47. 
Giddings, ethical dualism of, 196.

Green, T. H., referred to, 201.

Habits, social, 122.

Hagel, referred to, 27, 33, 257. Hobbes, referred to, 15, ff, 236. Hooker, quoted, 224.

Ideas, social, Ir6, 122.

Imagination, the social, 120.

Immigration, 29. -the problem of, 99 .

Individual and the social conscience, 165.

-the relation of,to the State, $35, \mathrm{ff}, 7 \mathrm{r}$.

Institutions, social, 44, ff.

-conserve social energy, 48.

-methods of growth, 5 I.

- the character of, 3 II.

Invention, the faculty of, 120.

Kant's view of the ideal, 124.

Kent, quoted, 242.

Kidd, referred to, I78.

Kingdom of God, defined, 173.

-and the kosmos, I74, ff.

-devalopment of, 255 .

Language, 96 .

Law-

-as the expression of life,

-defined, 229.

-how known, 230, ff. .

-its forms, 233, 237.

-its origin, 226.

Le Bon, quoted, r 30 .

Lewes, referred to, I72.

Locke, refarred to, 18 .
Lowell, quoted, 222.

Mackenzie, quoted, 35 .

Marx, referred to, III.

Mind, social, evidence for, 97 .

-its psychology, III, ff.

Morris, quoted, 27.

Monasteries and the social conscience, $\mathrm{r} 60$, $\mathrm{ff}$.

Moses, the legislation of, $7 \mathrm{I}, \mathrm{ff}$.

Natural selection, 148 .

- the popular ethical view, I8

Naturalization, defined, $3 \mathrm{I}$.

Nature of the state, 4 I.

Oath, official, 343 , ff.

Parliament, not sovereign, $2 \mathrm{I} 8$. Plato, the social theories of, 73 , 88 .

Race, psychic influence of, $9 \mathrm{I}$. Religion and the state, 63 .

-in social institutions, 49.

-as a social bond, 102.

Religious features in law, 322 , ff.

Responsibility of corporations,

Rousseau and individualism, 269. 77.

-idea of citizenship, 79.

-common will of, $8 \mathrm{I}$.

-quoted, 205.

Savigny, referred to, 233 .

School, its character, $3 \mathrm{I} 4$, ff.

Small, quoted, r8I.

Social problem, its nature, 14.

Spencer, referred to,

19, ff, 32,84 . 
State, defined, 26.

-a psychic organism, 39.

-and social institutions,.

44, ff. Unity, aided by social settle-

-biological view of, 19 , ff.

- genius of the, 94 .

-identified with Government,

17, -social, factors of, 9I, ff.

-its character, 305 , ff.

-legal conception of, I5.

-method of growth, $28,40$.

-psychological view of,

25,84 .

-who comprises the, 260 .

Stead, Herbert, quoted, 72.
Test, religious, $342, \mathrm{ff}$.

Tripolitan Treaty, 349. ments, 39.

-of church and government,

67.

Utilitarian view of ideal, I25.

Walker, quoted, I88.

Ward, referred to, 100 .

Weismann's view, $\mathrm{I77}$, $\mathrm{ff}$.

-criticised, 182 .

Will, social, $\mathrm{r} 36, \mathrm{ff}$. 

I 


\section{UNIVERSITY OF CALIFORNIA LIBRARY BERKELEY}

Return to desk from which borrowed.

This book is DUE on the last date stamped below.

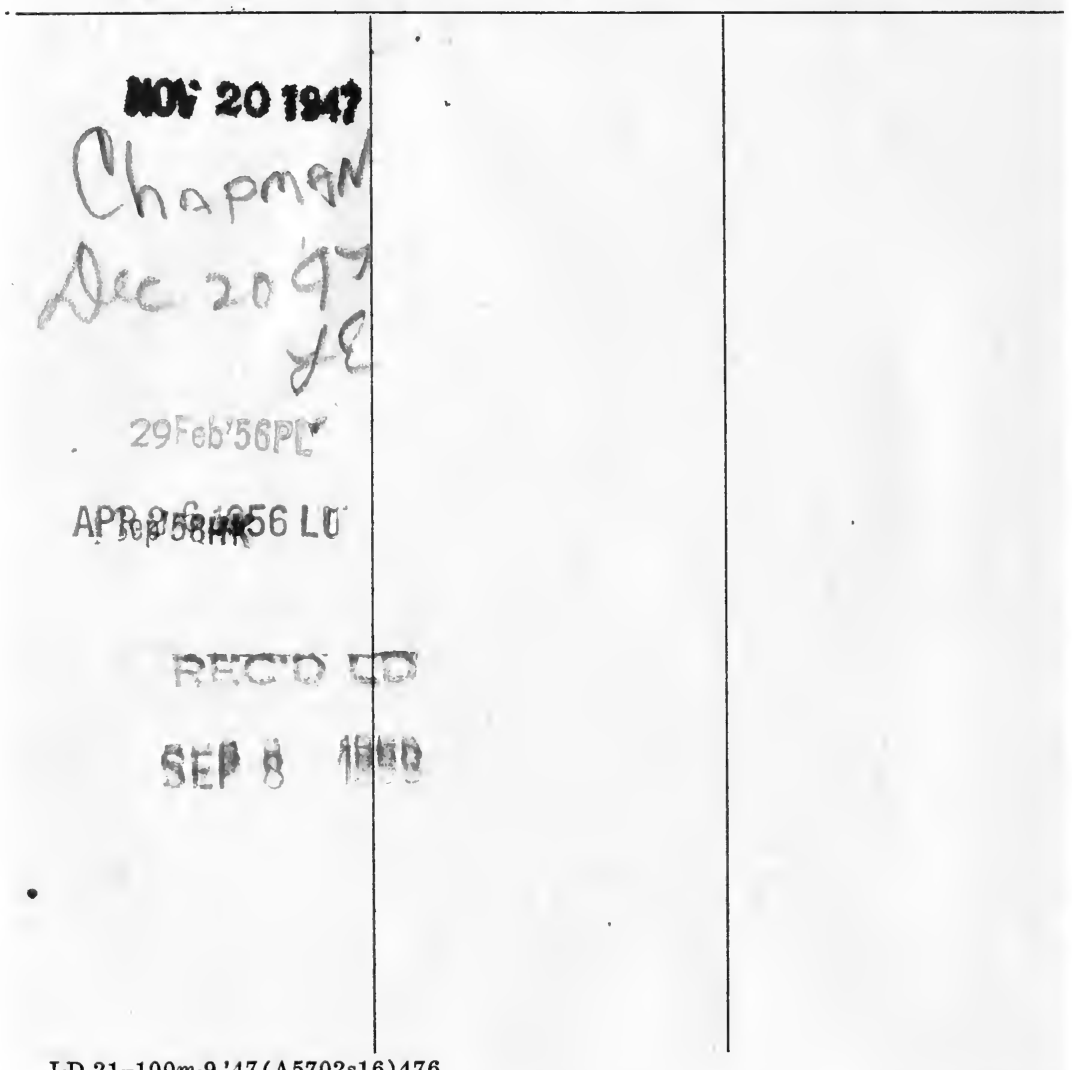

LD 21-100m-9,'47(A5702s16) 476 


\title{
YB 06967
}

\section{3}

\author{
$\mathrm{HM} 216$ \\ C.5 \\ 1922
}

THE UNIVERSITY OF CALIFORNIA LIBRARY 
